\title{
Phylogenetic relationships among arbuscular mycorrhizal fungal species in the deeply rooted archaeosporales (Glomeromycota)
}

Robert J. Bills

Follow this and additional works at: https://researchrepository.wvu.edu/etd

\section{Recommended Citation}

Bills, Robert J., "Phylogenetic relationships among arbuscular mycorrhizal fungal species in the deeply rooted archaeosporales (Glomeromycota)" (2015). Graduate Theses, Dissertations, and Problem Reports. 5211.

https://researchrepository.wvu.edu/etd/5211

This Dissertation is protected by copyright and/or related rights. It has been brought to you by the The Research Repository @ WVU with permission from the rights-holder(s). You are free to use this Dissertation in any way that is permitted by the copyright and related rights legislation that applies to your use. For other uses you must obtain permission from the rights-holder(s) directly, unless additional rights are indicated by a Creative Commons license in the record and/ or on the work itself. This Dissertation has been accepted for inclusion in WVU Graduate Theses, Dissertations, and Problem Reports collection by an authorized administrator of The Research Repository @ WVU.

For more information, please contact researchrepository@mail.wvu.edu. 


\title{
PHYLOGENETIC RELATIONSHIPS AMONG ARBUSCULAR MYCORRHIZAL FUNGAL SPECIES IN THE DEEPLY ROOTED ARCHAEOSPORALES (GLOMEROMYCOTA)
}

\author{
Robert J. Bills \\ Dissertation submitted to the \\ Davis College of Agriculture, Natural Resources and Design \\ at West Virginia University \\ in partial fulfillment of the requirements \\ for the degree of
}

Doctor of Philosophy
in
Agricultural Sciences

Joseph B. Morton, Ph.D., Chair

Alan J. Sexstone, Ph.D. Daniel G. Panaccione, Ph.D.

James D. Bever, Ph.D.

Jonathan R. Cumming, Ph.D.

Division of Plant and Soil Sciences

Morgantown, WV

2015

Keywords: Glomeromycota, rRNA gene evolution, arbuscular mycorrhizal fungi Copyright 2015 Robert J. Bills 


\title{
ABSTRACT \\ PHYLOGENETIC RELATIONSHIPS AMONG ARBUSCULAR MYCORRHIZAL FUNGAL SPECIES IN THE DEEPLY ROOTED ARCHAEOSPORALES (GLOMEROMYCOTA)
}

\begin{abstract}
Robert J. Bills
Arbuscular mycorrhizal fungi (AMF) in the phylum Glomeromycota are globally distributed biotrophic fungi that form symbiotic associations with a majority of terrestrial plants. Their global beneficial role in plant and soil ecology warrants a better understanding of their evolutionary history and taxonomic relationships. This project focused on species relationships in two deeply rooted families Ambisporaceae and Archaeosporaceae. In one study, analysis of morphology and 28S ribosomal DNA (LSU) sequences resulted in two major changes that redefined Ambispora to include only species that were dimorphic for both acaulosporoid and glomoid spore types. First, species described as producing only glomoid spores (Am. leptoticha, Am. fecundispora, and Am. callosa), only acaulosporoid spores (Am. jimgerdemannii), or both spore morphotypes (Am. appendicula) were synonymized with Ambispora leptoticha. LSU and more conserved 18S (SSU) sequences indicated little divergence between species. Second, Ambispora fennica was synonymized with Ambispora gerdemannii based on morphological and LSU sequence variation equivalent to that in the sister clade Am. leptoticha. With this analysis, Ambispora was reduced to three species: Am. leptoticha, Am. gerdemannii, and Am. granatensis. Morphological and molecular characters were given equal treatment in this study, as each data set informed and clarified grouping and ranking decisions. The two inner layers of the acaulosporoid spore wall were the only structural characters uniquely defining each of these three species; all other characters were shared. Phenotypes of glomoid spores were indistinguishable between species, and thus were informative only at the genus level. Evolution of sporogenous saccule was a convergent trait because it also evolved in other AMF families. In a second study, morphology and LSU sequence variation were compared in the only two Archaeospora species, Ar. trappei and Ar. schenckii. Both species form a precursor sporogenous saccule, but spores develop laterally (acaulosporoid) or within (entrophosporoid) the subtending hypha, respectively. In all other morphological characters, the two species are identical. One $A r$. schenckii and ten Ar. trappei strains grouped all taxa into one highly supported monophyletic clade. However, LSU sequences of Ar. trappei strains segregated into two subclades, with $A r$. schenckii grouping in one of the Ar. trappei clades. This evidence indicates the entrophosporoid mode does not represent a speciation event, but rather is a stable dimorphism within one or more populations of a single species. Therefore, Ar. schenckii and Ar. trappei were considered conspecific and synonymized as Ar. trappei. The combination of molecular and morphological evidence exposed the entrophosporoid mode as a polymorphism that likely was fixed in a founder asexual population and then was heritable and stable in the absence of recombination or negative selection pressures. Spore dimorphism is not a rare event, occurring also in the previous study. LSU sequence divergence between the two Ar. trappei clades was greater than that within the clade containing Ar. trappei and Ar. schenckii strains. This distinct subclade structure suggests fixation of discrete variants typical of clonal reproduction and possible retention of polymorphisms in rDNA repeats. The broader implication from this result is that clade topology alone may not provide an adequate criterion for ranking at the species level.
\end{abstract}




\section{Dedication}

Evidence for evolution, a natural phenomena about patterns of descent from common ancestry and relatedness of "kinds", speaks for itself. For those who overlooked it in the Bible:

"Then God said, 'Let the earth bring forth grass, the herb that yields seed, and the fruit tree that yields fruit according to its kind, whose seed is in itself, on the earth'; and it was so. And the earth brought forth grass, the herb that yields seed according to its kind, and the tree that yields fruit, whose seed is in itself according to its kind. And God saw that it was good."

Genesis 1: 11-12 (NKJV).

The evolution of plants, ancestor descendant relationships, brought forth from this earth, "according to its kind." 


\section{Acknowledgements}

Most importantly, I would like to thank God. His grace has been my source of strength, peace, love and safety. My faith in Him has made this accomplishment possible.

I am especially thankful to Rick and Debbie Mullens. They opened their home, shared their faith and made me a part of their family. They are two of the most generous and selfless people I have ever met. They showed me what it means to love, forgive, share, and the freedom that comes from serving others.

I would like to express my gratefulness to Dr. Joseph Morton for the opportunity to come to WVU and investigate these fungi. I am grateful to my committee members for their guidance, insight, mentorship, participation and patience: Dr. Jonathan Cumming, Dr. James Bever, Dr. Daniel Panaccione, and Dr. Alan Sexstone. I am also very grateful for the mentorship and support I received from so many faculty here at WVU: Gary Bissonnette, Donna Ford-Werntz, Daniel Frank, Mannon Gallegly, James Kotcon, Bill MacDonald, Youyoun Moon, Mahfuzur Rahman, Katrina Stewart, Michelle Withers, and Jinbao Yao.

Thank you, Katrina Stewart, Bill Wheeler and Mark Double for the wonderful stories, great moments of laughter, and your friendship.

A special thank you goes to Dr. Stewart, Dr. Bissonnette, and Dr. Baker for their encouragement, guidance, and leadership. Also to Dr. Bever and Dr. Schultz for their generosity and patience during my many visits to Bloomington.

I am also grateful for all of the wonderful friendships with so many students and officemates who have blessed me with their laughter, smiles, snacks and stories: Krissy Anderson, Yulia Bilovol, Greg Boyce, Christine Coyle, Alisha Daley, Derrick Donnaly, Jordan Eggers, Mariana Farcas, Tiff Fess, Crystal Golden, Shawn Kenaley, Greg Klinger, Megan Krug, Matt Maust, Dave McCann, Matt McCarroll, Sarah Mills, Chris Moore, Zola Msiska, Prashanthi Mulinti, Sonia Purin, Katy Ryan, Smita Singh, Baneshwar Singh, Ellie Spahr, Ally Tenney, Becky Uphold, Lisa Valencia, Bob Voshel, Russell Young. 


\section{TABLE OF CONTENTS}

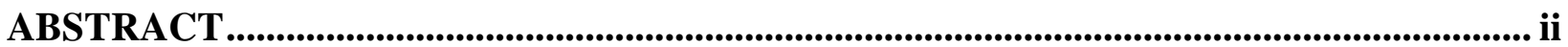

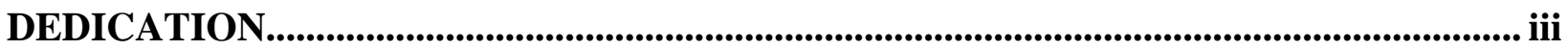

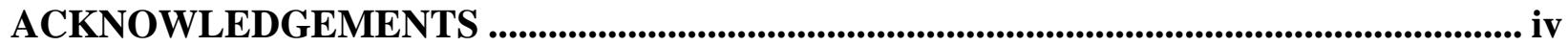

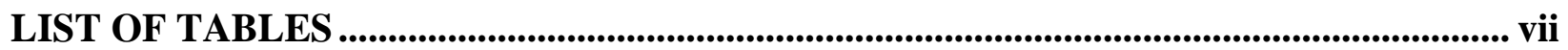

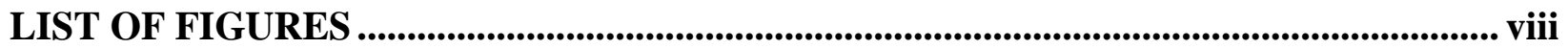

CHAPTER 1. LITERATURE REVIEW ......................................................................

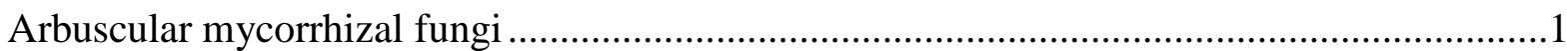

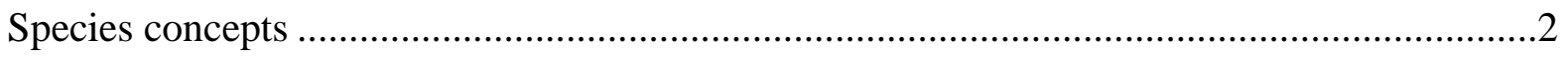

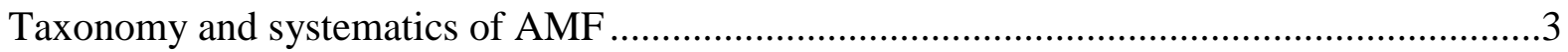

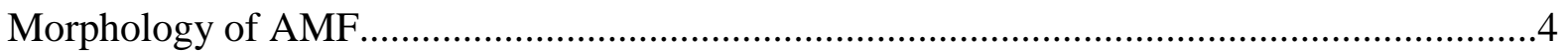

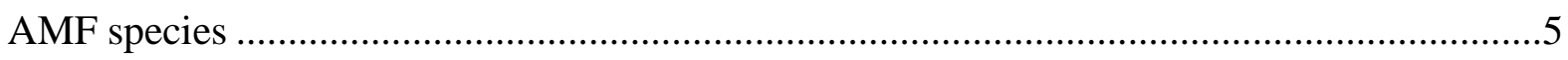

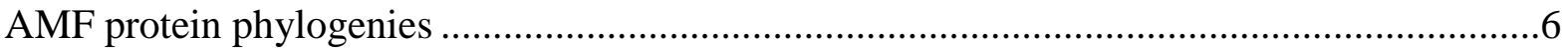

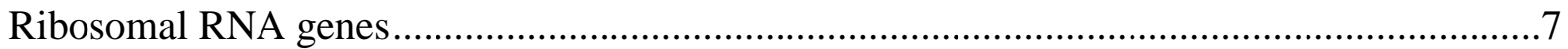

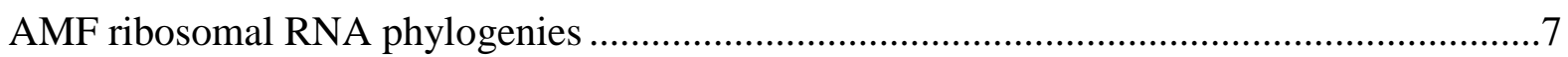

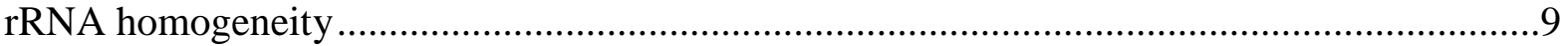

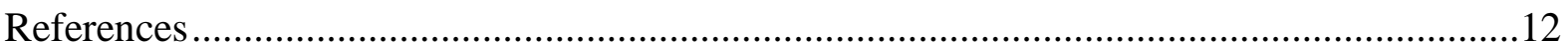

CHAPTER 2. A COMBINATION OF MORPHOLOGY AND 28S RRNA GENE

SEQUENCES PROVIDE GROUPING AND RANKING CRITERIA TO MERGE

EIGHT INTO THREE AMBISPORA SPECIES (AMBISPORACEAE,

GLOMEROMYCOTA).........................................................................................................................23

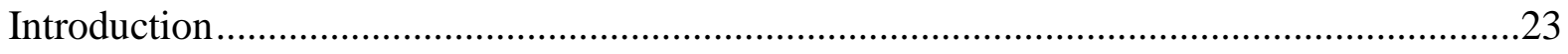

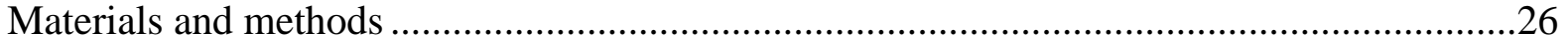

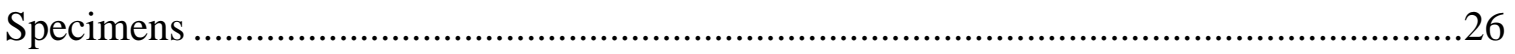

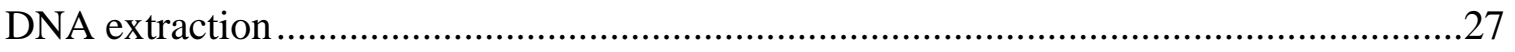

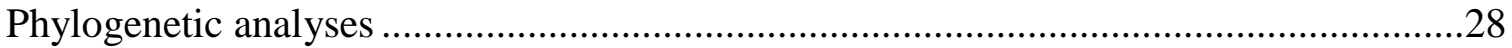

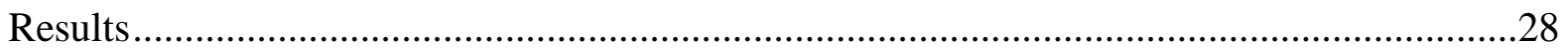

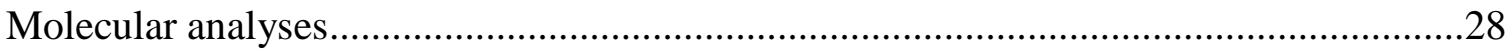

Morphological analyses ........................................................................................29

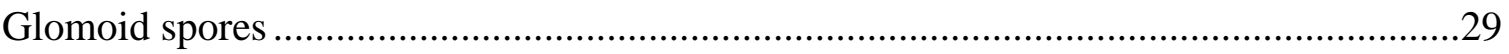




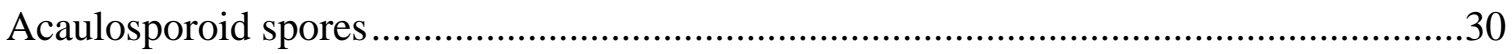

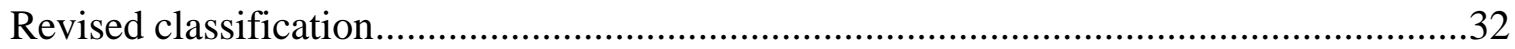

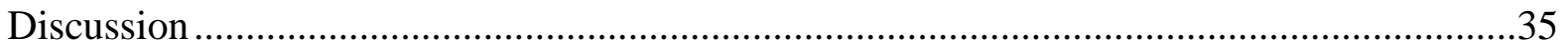

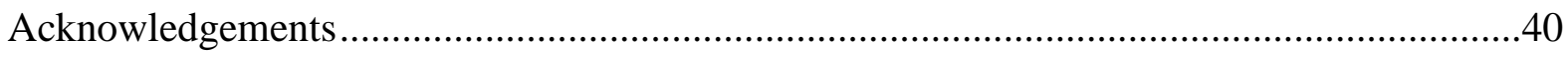

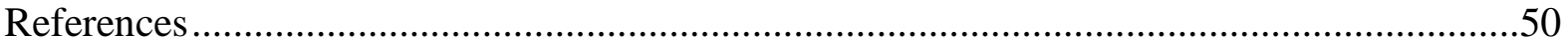

\section{CHAPTER 3. MORPHOLOGY AND AN LSU PHYLOGENY REVEAL} ARCHAEOSPORA TRAPPEI AND AR. SCHENCII ARE SYNONYMOUS AND MODE OF SPORE FORMATION RESOLVES ONLY STABLE POPULATION-

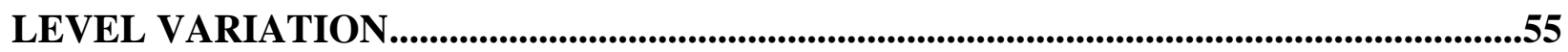

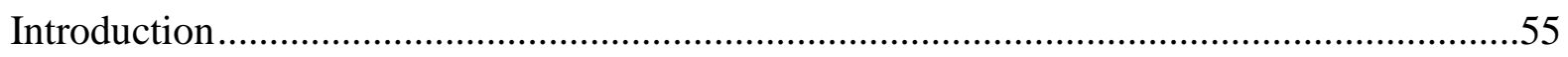

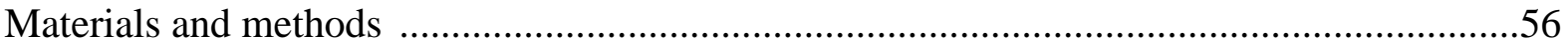

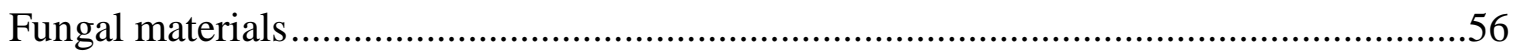

DNA extraction, amplification and sequencing rDNA ..........................................57

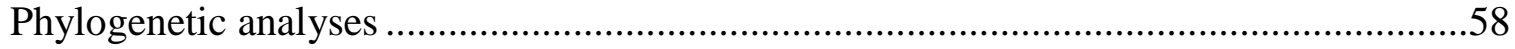

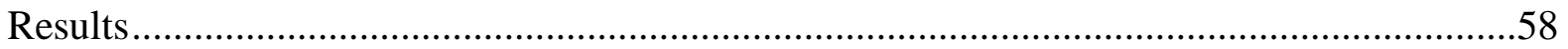

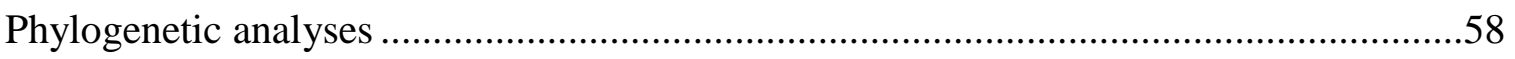

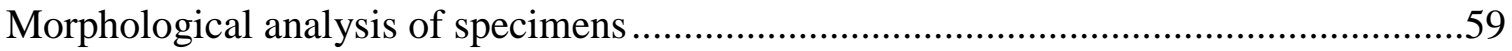

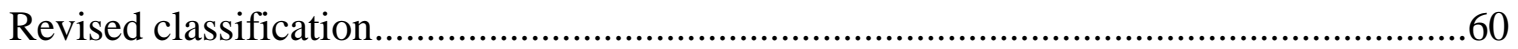

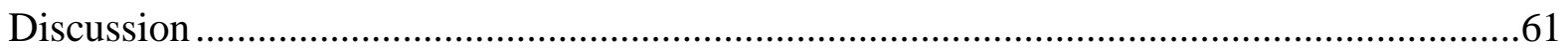

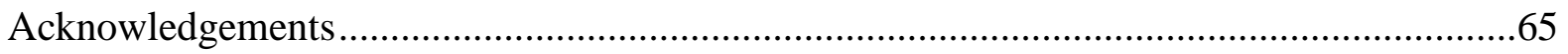

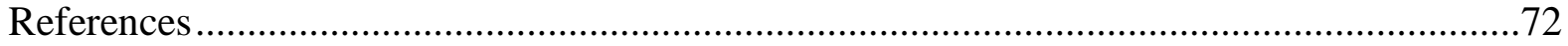

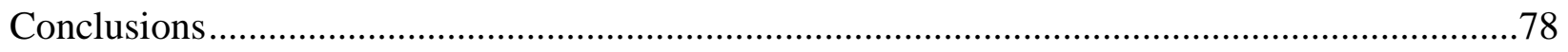

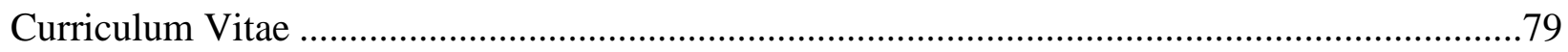




\section{LIST OF TABLES}

Chapter 3 - Table 1. Estimates of evolutionary divergence (standard error) between groups of partial LSU rDNA sequences from deeply rooted taxa in Glomeromycota. Groups compared included both Archaeospora trappei subclades, Ar. schenckii, Ambispora gerdemannii, Am. leptoticha, Paraglomus brasilianum, and P. occultum. The average distance was calculated from the arithmetic mean of all pairwise distances between groups in the inter-group comparisons. Analysis conducted in MEGA6 using the Kimura 2-parameter model + gamma $($ gamma distribution $=4)$

Chapter 3 - Table 2. A summary of spore size and subcellular diagnostic characters of Archaeospora schenckii and Archaeospora trappei reported in previous studies. 


\section{LIST OF FIGURES}

Chapter 1 - Figure 1. Classification of the phylum Glomeromycota down to genera based on rDNA phylogeny in Redecker et al. (2013)

Chapter 1 - Figure 2. Schematic representation of a partial single nuclear ribosomal RNA (rRNA) gene. Primer arrows indicate the direction of amplification each primer. Top red arrows indicate universal eukaryotic-species primers used in first round PCR amplification. Bottom blue arrows indicate fungus-specific primers used in second round PCR (White et al., 1998; van Tuinen et al., 1998b; Trouvelet et al., 1999)

Chapter 2 - Figure 1. Timeline summarizing major taxonomic revisions in Ambispora (Ambisporaceae).

Chapter 2 - Figure 2. Phylogenetic tree from partial 28S (LSU) sequences reconstructed using the Kimura-2 parameter and the maximum likelihood criterion in MEGA6. Bayesian posterior probabilities greater than 0.97 represented by thickened branches. Branch labels specify: spore morphotype ( $\mathrm{ac}=$ acaulosporoid, $\mathrm{gl}=$ glomoid) and source material (spore1, spore2, spore3) for each transformant clone, INVAM accession, and NCBI accession code. Only bootstrap values above $70 \%$ are designated. **A third party sequence submitted to GenBank and erroneously annotated as Glomus gerdemannii.

Chapter 2 - Figure 3. Comparative morphology of glomoid spores produced by Ambispora species. All form a bilayered spore wall consisting of a somewhat friable hyaline to pale brown outer layer (L1) and a hyaline semi-pliable inner layer (L2) that is continuous with a bilayered (L1-L2) subtending hyphal wall. a Small specimen of Glomus leptotichum holotype OSC40249. b Typical specimen from G. leptotichum OSC40249. c Spore of Ambispora leptoticha from active culture FL184B. d Spore and subtending hypha of Am. leptoticha FL184B. e Spore and subtending hypha of Glomus fecundisporum OSC40250. f Spores and attached hyphae from Acaulospora gerdemannii holotype OSC37514. g Small spore from Ac. gerdemannii OSC37514. h Transition between spore and subtending hyphal wall of Acaulospora appendicula isotype FLAS F53673. i Spore of Ambispora gerdemannii 
MT106 with transition between bilayered spore wall and subtending hyphal wall. $\mathbf{j}$ Spore of Am. gerdemannii ON205. k-l Spores from Ambispora granatensis isotype Z+ZT isotype 555503. $\mathrm{Bar}=10 \mu \mathrm{m}$.

Chapter 2 - Figure 4. Comparative morphology of whole and broken spores of Glomus callosum holotype OSC147148 (a-c) and glomoid spores of Ambispora leptoticha FL184B after nine months in refrigerated dry storage (d-f). a Whole spores in 5\% formalin (size range 60-310 $\mu \mathrm{m}$ ). b Typical spore with a friable outer layer (L1) and thicker semi-pliable inner layer (L2). c Thinner-walled spore. d Whole spores in water (size range 72-290 $\mu \mathrm{m}$ ). e Typical spore showing semi-pliable phenotype of inner spore wall layer (L2). $\mathbf{f}$ Thinnerwalled spore. Bar for a, $\mathrm{d}=250 \mu \mathrm{m}$, all others $=10 \mu \mathrm{m}$ .46

Chapter 2 - Figure 5. Comparative morphology of acaulosporoid spores produced by known Ambispora species. All form a friable and sloughing outer spore wall layer (L1), with divergence between species expressed in phenotypes of the second (L2) and inner (L3) layers of the spore wall. The middle spore wall layer (L2) is continuous with the wall of the pedicel (P) which branches from the neck of a sporiferous saccule. a Am. leptoticha FL130A, b Am. gerdemannii ON205A c Am. granatensis Z+ZT isotype 55-5504. A thick hyaline semipliable inner wall that forms separately from the spore wall (iw) varies in number and thickness of separable layers, but this phenotypic variation is shared by all three species. Bar $=5 \mu \mathrm{m}$.

Chapter 2 - Figure 6. Comparative morphology of the acaulosporoid spores of Ambispora species. a Spores of Am. leptoticha FL130A in water showing various stages of degradation/sloughing of the outer spore wall layer (OL) exposing the bright white ornamented inner spore wall layer (L3). b Cerebriform phenotype of spore wall outer layer from Acaulospora gerdemannii OSC37514. c Crazed phenotype of spore wall outer layer from Ac. appendicula OSC41495. d-f Spores sampled at the same time from an active culture of Am. leptoticha FL130A showing variation in phenotypes of the outer spore wall layers. d Crazed phenotype. e Crazed and cerebriform regions of the outer layer on the same spore. $\mathbf{f}$ Cerebriform phenotype. Bar for $\mathrm{a}=200 \mu \mathrm{m}$, for all others $=25 \mu \mathrm{m}$. 
Chapter 2 - Figure 7. Equivalence in comparative morphology of acaulosporoid spores of Ambispora fennica and Ambispora gerdemannii. Spores of Am. fennica spores mounted on slides labeled Att550-30 from J. Blaszkowski (a-c). a In Melzer's reagent, showing the dextrinoid reaction of a friable outer spore wall layer (L1), a more permanent second layer (L2), a fracturing rigid inner layer (L3), and a semi-flexible inner wall (iw). b In PVLG, with the outer layer of the spore wall (L1) mostly sloughed. c Spore with all layers of the spore wall (L1-L3) and inner wall (iw) present. Spores of Am. gerdemannii strain MT106 (d-f). d In Melzer's reagent. e In PVLG with only remnants of the outer spore wall layer (L1) present. f All layers of the spore wall (L1-L3) and inner wall (iw) present. Bar $=10 \mu \mathrm{m}$.

Chapter 3 - Figure 1. MrBayes phylogenetic tree reconstructed from partial 28S (LSU) gene sequences using the Kimura 2 parameter plus gamma $(\mathrm{K} 2 \mathrm{P}+\mathrm{G})$ model. Maximum likelihood (ML) tree had identical topology. Bayesian posterior probabilities greater than 0.97 are depicted by thickened branches, and ML bootstrap values greater than $70 \%$ are designated above the branches. Branch labels sequentially specify: source material, INVAM accession and (NCBI accession number). All new sequences Ar. schenckii CL401 sequences were generated from four single spore strains (ss1, ss2, ss3 or ss4). The tree was rooted by Geosiphon pyriformis.

Chapter 3 - Figure 2. Equivalence in comparative spore morphology of Archaeospora trappei that develop from the hypha of a precursor sporiferous saccule, either laterally (acaulosporoid) or internally (entrophosporoid). Spores are hyaline, with a thin semi-flexible outer spore wall layer $(L 1)$, a more permanent, semiflexible second layer $(L 2)$ and a thicker flexible, finely laminate inner wall $(i w)$ that form wrinkles and folds in crushed spores. The outer spore wall layer $(L I)$ is continuous with the wall of the sporiferous saccule and subtending hyphal wall. Cicatrices, circular ridges or scars, may be detected at points of contact with the hypha subtending the saccule. Whole spores from Ar. trappei NB112 in water showing variation in acaulosporoid phenotype (A). Juvenile acaulosporoid spore (SP) forming laterally from the hypha subtending (SH) a sporiferous saccule (SS) from CL401 (B). Intact acaulosporoid spore with outer spore wall layer (L1) continuous with hyphal wall 
subtending a sporiferous saccule with fully differentiated second layer (L2) and inner wall (iw) from JA101C (C). Variation in acaulosporoid spore outer layer (L1) and hypha subtending a sporiferous saccule from AZ119A (D). Differentiated acaulosporoid spore with partially degraded spore wall outer layer $(L 1)$ and missing diagnostic hypha subtending a sporiferous saccule from MX116 (E). Juvenile entrophosporoid spore (SP) forming within the hypha subtending (SH) a sporiferous saccule (SS) from CL401 (F). Intact entrophosporoid spore within the hypha (L1) subtending a sporiferous saccule with second layer of the spore wall (L2) and inner wall (iw) from CL401 (G). Variation in differentiated entrophosporoid spore with partially degraded outer spore wall layer (L1) from CL401 (H). Differentiated entrophosporoid spore with partially degraded outer spore wall layer $(L I)$ and missing diagnostic subtending hypha and saccule from CL401 (I). Bar A represents $100 \mu \mathrm{m}$ Bars B-I represents $5 \mu \mathrm{m}$ 


\section{Chapter 1}

\section{Literature Review}

\section{Arbuscular mycorrhizal fungi}

Arbuscular mycorrhizal (AM) fungi in the phylum Glomeromycota (Schüßler et al. 2001) are globally distributed, asexual fungi that form obligate symbioses with the roots of the majority of terrestrial plants (Smith \& Read 2008) and one non mycorrhizal species that forms an endosymbiosis with cyanobacterium (Schüßler 2002). Fossil evidence suggests that AM fungi have been symbiotic with terrestrial vegetation for at least 400 million years (Remy et al. 1994). The origins of this ancient association may have been a critical factor for the emergence of plants on to land. Their subsequent intimate coevolution (Pirozynski \& Malloch 1975; Morton 1990; Redecker et al. 2000a) and global distribution makes their symbiotic association one of the most widespread in nature (Fitter 2005; da Silva et al. 2006; Kivlin et al. 2011).

Arbuscular mycorrhizal fungi establish a symbiotic relationship colonizing roots of plants (intra radical hyphae) and the surrounding soil (extra radical hyphae) in a reciprocal exchange of carbohydrates moving from the host to the fungus and inorganic resources moving from the fungus to the plant (Allen 1991; Smith \& Read 2008). Extra-radical hyphae growing out past the depletion zone of the host rhizosphere are extremely efficient at scavenging inorganic phosphorus, nitrogen, copper, and zinc (Cui \& Nobel 1992; Smith \& Read 2008). In addition to well documented improvement to host nutrition, AMF have also been shown to improve resistance to root pathogens (Newsham et al. 1995), tolerance to drought (Augé 2004), and increase plant fitness (Janos et al. 1980; Koide 1991). AMF diversity has also been shown to differentially influence plant diversity and productivity (van der Heijden et al. 1998; Vogelsang et al. 2006), influence plant tolerance to herbivory (Bennet \& Bever, 2007), provide tolerance to heavy metals (Toler et al. 2005), and provide aluminum resistance in acidic soils (Kelly et al. 2005; Klugh \& Cumming 2007).

Ecosystem factors that influence the diversity and distribution of AMF species have included investigations of edaphic characters and plant community composition (Lekberg et al. 2007; Antoninka et al. 2015; Krüger et al. 2015, Davison et al. 2015). These investigations included differences in soil type, soil $\mathrm{pH}$, soil nutrient levels, land-use history, and the composition of the plant community at a variety of scales. 


\section{Species Concepts}

One of the oldest problems in biology is the absence of a universally accepted definition of species, the basal category in the Linnaean taxonomic hierarchy (De Queiroz 1988). A species is a collection of populations delimited by diagnosable conserved traits that are stable across time and space (Mishler 1985; Morton 1990; Baum 1992; Davis \& Nixon 1992; Davis 1996; Mishler $\&$ Theriot 2000). As units of evolution, members evolve together collectively because of shared selection pressure(s) or a common developmental constraint (Ereshefsky 1991), gene flow (Mayer 1942) or other biological process unique to the organisms being investigated (Mishler 1985). All species concepts explore a theory of a process of speciation and consist of two separate classification processes of grouping and ranking taxa (Mishler \& Theriot 2000). Disagreements over how to conceptually define ranking and grouping criteria, both morphologically and molecularly, can lead to conflicting taxonomies, which can cause misinterpretation of phylogenetic patterns and processes (Ereshefsky 1991).

The number of species concepts developed by biologists is inexplicably large and varied (Coyne \& Orr 2004). The species concept used for this study was based on the phylogenetic species concept. The phylogenetic species concept was first proposed by Joel Cracraft in 1983 to incorporate evolutionary processes into an explanation for the origin and maintenance of species (Cracraft 1983). The theoretical basis for this concept was that each species originates via an ancestor-descendant relationship regardless of a taxon's biology or ecology. Grouping criteria was based on monophyly, where taxa form clades based on relatedness of shared unique, homologous characters. Ranking criteria were based on congruence between all informative character sets that establish inclusiveness among members. The phylogenetic species concept is the most appropriate for delimiting asexual organisms, including AMF species, because evolution is a universal process. Phylogenetic methods are applicable to all characters, monophyly is applicable to all living organisms, and there is only one unique causal force for any given species, which serves to unite the taxon (Horvath 1997).

Testing for homology is different for morphological and molecular characters. Morphological characters are tested for homology by evaluating similarity in ontogeny, tree topography and composition and conjunction (co-occurring structures in the same organism) and congruence of phylogenetic characters (Patterson 1982; Patterson 1988; de Pinna 1991). None of these tests are available for molecular characters and so statistical algorithms have been 
developed to assess if nucleotide and amino acid similarity is greater than might be anticipated by chance alone (Patterson 1988).

Analysis of molecular characters often starts with an alignment containing gene sequences from multiple taxa with an assumption that nucleotide position in one sequence is matched to homologous positions in the other. A distinction between orthologous sequences (latest common ancestry through gene divergence) and paralogous sequences (latest ancestry through gene duplication) must also be made (Patterson 1988; Olsen \& Woese 1993; Baum \& Smith 2013). Coyne \& Orr (2004) state that the evolutionary history of each gene is unique. Although a gene phylogeny may provide a history of gene evolution that can be correlated to the evolution of a species, it may conflict with the phylogeny of a different gene. Caution is required to distinguish gene phylogenies (which represent evolution of a specific gene at one scale) with species phylogenies (evolution of all the characters of a species) (Pamillo \& Nei 1988). The basal units of evolution are species, each of which is distinguished by discrete characters that identify unique common ancestry (Patterson 1982). All independent morphological and molecular character sets (gene phylogenies) that inform on the continuity of descent need to be in congruence to determine a true species phylogeny (Coyne \& Orr 2004; Morton 2009).

\section{Taxonomy and systematics of AMF}

The taxonomy and systematics of AM fungi continue to be contentious as efforts to characterize taxa at a variety of levels have failed to achieve a biologically informative operational classification (versus a consensus classification) that has universal acceptance among researchers (Morton 2009; Oehl et al. 2011; Redecker et al. 2013). Redecker et al. (2013) recently published a revised monophyletic classification of the Glomeromycota based on the collaborative efforts of a group of systematists experienced in the biology and taxonomy of AM fungi (Fig 1). The reconstruction of evolutionary history and identification of ancestor/descendant relatedness among taxa helps organize a classification system of inclusive hierarchal groups from the least inclusive group (species) to the most inclusive (Phylum).

Mycorrhizal structures may appear to have similar structures and functions at all ranks in a classification and among species. During analysis, these must be identified as either homologous or analogous. Homology is a hypothesis of similarity due to descent from a common ancestor (Patterson 1988). Therefore, homologous characters are phylogenetically 
informative because they define monophyletic groups (Patterson 1982; De Queiroz 1988). In contrast, analogous characters are similar due to independent evolution and are not considered to be a derived from a recent common ancestor. Analogous characters have different evolutionary histories, so they create "noise" that can complicate phylogenetic analyses.

Efforts to characterize the fungal component of the mycorrhizal association functionally, taxonomically, ecologically, and by molecular analysis have been hampered by the absence of a universally accepted operational species concept (Røsendahl 2007; Redecker et al. 2014). Morton (1990) evaluated a variety of contemporary species concepts and their applicability to AM fungal evolutionary relationships. At that time he found that a combination of phenetic and evolutionary concepts provided a satisfactory method for defining the unique biological properties of these asexual fungi. Vegetative structures (arbuscules, vesicles) and biochemical features (staining reaction) in roots are highly variable and resolved only conflicts at the family level. Species level characters were important because they provided a more accurate assessment and explanation of the evolution and maintenance of the AM symbiosis (Morton 1990).

\section{Morphology of AMF}

Morphological characters that are stable and phylogenetically useful can be defined empirically from developmental patterns and processes for application to taxonomic problems. The identification of the initiation and termination of spore characters and the order and sequence of events of subcellular character differentiation and transformation can be hierarchically ordered and used for comparisons between individuals and other taxa. Comparative ontogeny has been described for species in Scutellospora (Franke \& Morton 1994; Morton 1995), Gigaspora (Bentivenga \& Morton 1995), Glomus (Stürmer \& Morton 1997), and Acaulospora (Stürmer \& Morton, 1999). Ontogenic interpretations (Franke and Morton 1994; Stürmer \& Morton 1997, 1999) of the morphological features of AMF spores provide criteria to test for character homology and therefore help determine the phylogenetic significance of these characters (Morton 1988; Morton \& Benny 1990). Mycorrhizal structure and organization, and mode of spore germination along with spore primary characters (i.e., spore wall, inner flexible walls, and germination shield) and secondary characters (layers that develop within each primary character) define genus and higher-level rankings. Mode of spore formation from a sporiferous saccule, which occurs early during spore ontogeny, has recently been shown to be a convergent trait that 
discriminates at species level in some lineages (Kaonongbua et al. 2010) and as a population variant in others (Morton \& Redecker 2001; Bills \& Morton 2015). Tertiary characters, which contain all the variation that occurs within each layer (i.e., color, thickness, and ornamentation), define species (Franke \& Morton 1994; Morton et al. 1995; Bills \& Morton 2015).

\section{AMF species}

The use of spores and their subcellular structures to characterize species composition of AMF communities has some limitations (Morton et al. 1995). Some AMF species elude detection because they cannot be induced to sporulate in pot cultures. Often, spores collected from fieldsamples lack the complete range of phenotypic variation or are in poor condition due to degradation and senescence that diagnostic characters are missing or obscure (Morton 1993; Røsendahl 2007). Identification of spore diagnostic characters provides additional challenges. Adequate sampling and use of voucher specimens from many populations and closely related species is necessary to identify the range and stability of phenotypic variation. This helps reduce the misinterpretation of population level characters as discrete species level characters (Bills \& Morton 2015). Due to the challenges and limitations of morphology-based identification, the advent of DNA analyses ushered in an era of new molecular tools that have been applied to classification of AMF.

The number of described AM fungal species continues to be a matter of debate due to the lack of a universally accepted species concept among researchers and a failure to identify suitable morphological and molecular criteria for grouping and ranking taxa (Redecker \& Raab 2006; Morton 2009; Schüßler \& Walker 2010; Redecker et al. 2013). Many recent taxonomic revisions by Oehl et al. (2011) have been criticized and rejected due evidence that analyses and interpretations were based on selective and poor data (Redecker et al. 2013). Historically, confusing and inconsistent morphological terminology used to describe spore wall characters (Walker 1983), the relatively low number of morphologically described and sequenced taxa, and the preferential use of rRNA genes for phylogenetic analyses all contribute to maintaining a confusing and contentious species concept (Morton 2009). Another issue is a necessity for accurate identification of homologous characters that can be used to group and rank AMF into clades as unique and discrete entities that are stable over time, regardless of environment (Morton 1993). The majority of biologists define species based on a lineage that maintains its 
identity following a unique origin (Røsendahl 2007). Differences between AMF research groups on how to define the evolutionary significance of diagnostic spore wall characteristics confuses identification of novel characters that are needed to group and rank taxa. Contradictory phylogenies based solely on either morphological data or molecular analysis of SSU rDNA has also produced conflicting phylogenies that warrant further analyses (Walker \& Schüßler 2004; Morton 2009; Schüßler \& Walker 2010).

With the advent of tools for DNA analyses, additional controversies occurred when phenotypic patterns of relatedness were contradicted by molecular phylogenies (Morton \& Benny 1990; Morton 2009). Morton \& Benny (1990) erected two suborders, Glomineae and Gigasporineae, based on differences in the inner wall development, mycorrhizal structures, infectivity patterns of hyphal fragments, fatty acid chemistry and cell wall chemistry. Specifically, $\beta$ (1-3) glucan were detected in Glomineae (species now identified from the genera Rhizophagus, Funneliformis, and Acaulospora) but not in Gigasporineae (Gigaspora and Scutellospora) (Gianinazzi-Pearson et al. 1994). Schüßler et al. (2001) SSU gene phylogeny showed a conflicting history reclassifying Acaulospora (Acaulosporaceae) as a sister clade to Gigaspora and Scutellospora (Gigasporaceae).

\section{AMF protein gene phylogenies}

AMF investigators pursued other genomic regions for single copy genes that could be phylogenetically informative. These studies included elongation factor 1-alpha (EF1 ), actin (act), $\alpha$-tubulin, $\beta$-tubulin, $\mathrm{H}^{+}$-ATPase, and two RNA polymerase II subunits $(R P B 1, R P B 2)$ (Helgason et al. 2003; Corradi et al. 2004a, 2004b; James et al. 2006; Redecker \& Raab 2006; Msiska \& Morton 2009a, 2009b; Morton \& Msiska 2010a, 2010b; Stockinger et al. 2014). All supported the rDNA phylogeny that the Glomeromycota are a monophyletic group. Most protein gene trees were also discordant with morphology based hypothesis and placed Acaulosporaceae and Gigasporaceae as sister clades. The presence of gene copy number polymorphisms and pseudo genes in some clades was also detected (Corradi et al. 2007; Msiska \& Morton 2009a, 2009b). Other incongruent topologies at deeper nodes also revealed conflicting identity with a sister clade to Glomeromycota (Helgason et al. 2003; Corradi et al. 2004a, 2004b; James et al. 2006). 


\section{Ribosomal RNA genes}

Ribosomal RNA genes are found in the DNA of all living organisms making them ideal candidates for testing hypotheses about species, evolution, and relatedness of life. The rDNA gene is the most utilized marker for phylogenetic reconstructions that included bacteria, archaea, plants, animals, and fungi including AMF (Sogin 1990; Olsen \& Woese 1993; Buckler et al. 1997; Reddy et al. 2005; Sonnenberg et al. 2007; Røsendahl 2007). In eukaryotes, these genes are located in a nucleolus, a membraneless compartment within the nucleus. The cellular demand for ribosomes and their protein products required for cell function and growth require tandem arrays of multiple repeats of the rRNA gene (Olson \& Dundr 2005; Eikbush \& Eickbush 2007). These tandem arrays of repeats are located either on single or multiple chromosomes, which are collectively called the nucleolus organizer regions (NORs) and are the location of nucleolus formation (Fatica \& Tollervey 2002; Dez \& Tollervey 2004; Fromont-Racine et al. 2005; Raška et al. 2006; and references therein). The proximity rRNA gene repeats within the nucleolus during cell cycle may play a role in homogeneity observed in these genes.

\section{AMF rDNA phylogenies}

Simon et al. (1992) and Helgason et al. (1998) were among the earliest that developed PCR primers to amplify SSU rDNA from AM fungal colonized roots. However, these early primers failed to amplify sequences from all AMF groups or lacked AMF specificity leading to amplification of non-mycorrhizal organisms. Schüßler et al. (2001) overcome these challenges with near full-length SSU sequences. This provided evidence for monophyly of AMF and a new phylum, Glomeromycota (Schüßler et al. 2001). Current use of SSU gene phylogenies have been

for identification of AMF community composition in roots in a variety of ecosystems (Öpik et al. 2009). The low level of DNA variation in SSU fragments, amplified with primers AM1-NS31, often lacked species level resolution (Stockinger et al. 2010). An inability to match all environmental sequences to well-defined AMF isolates led to phylogenetic reconstructions of sequence groups to be defined as virtual taxa (VT) (Öpik et al. 2009, 2013).

New primers targeting ITS region were developed (White et al. 1990; Gardes \& Bruns 1993). The ITS sequences contained greater variability than the SSU, but was also highly polymorphic due to the high number of insertions and deletions both within spores, within isolates and among closely related species. This rendered ITS sequences difficult to interpret, 
especially when comparing closely related species (Sanders et al., 1995; Lloyd-Macgilp et al. 1996, Stockinger et al. 2010). In contrast, the LSU gene region has been shown to resolve species (van Tuinen et al. 1998a, 1998b; Gollette et al. 2004; Krüger et al. 2009).

Van Tuinen et al. (1998b) developed primers at the 5' end of the LSU for the identification of AMF colonizing roots. The amplification product obtained from single spore and root DNA was a fragment roughly 750 bp in length and spanned the D1 and D2 region (Fig 2; van Tuinen et al. 1998). These primers have been used successfully to genotype a variety of AMF species (Kjøller \& Røsendahl 2000; Kjøller and Røsendahl 2001; Rodriguez et al. 2005; Stukenbrock and Røsendahl, 2005). The LSU gene amplified from single spores has also been used to clarify phylogenetic relatedness among closely related species (Kaonongbua et al. 2010; Morton and Msisk 2010a, 2010b; VanKuren et al. 2013; Bills \& Morton 2015). The LSU gene phylogenies were congruent with morphological analyses making the LSU a suitable tool to resolve species. This was attributed to presence of conserved regions of the LSU that allowed discrimination among species and variable regions that allowed discrimination within species (Buckler et al. 1997; Eickbush \& Eickbush 2007; Sonnenberg et al. 2007; Morton \& Msiska 2010a, 2010b; Bills \& Morton 2015). The LSU phylogenies have been shown not to be suitable for resolving deeper nodes in phylogenetic reconstructions (Stockinger et al. 2010).

Krüger et al. $(2009,2012)$ and Stockinger et al. (2010) developed AM fungal specific degenerate primers that amplify a $1.5 \mathrm{~kb}$ rDNA fragment that spanned the SSU-ITS-5.8S-LSU. Stockinger et al. (2010) compared sequence data from all rDNA gene regions to identify a suitable bar code, defined as a tool for sequence-based identification of species. Their analyses confirmed the highly polymorphic nature of rDNA genes within some species, but were unable to identify a universal level of interspecific variation suitable for identifying species. Their interpretation of their results also recommended the use of their primers for the best species level resolution. Although the benefit of the longer $1.5 \mathrm{~kb}$ amplification product allowed greater resolution at deeper nodes in phylogenetic analyses, the inclusion of the highly variable ITS required use of LSU region to anchor the alignment (Krüger, personal communication). 


\section{rRNA gene homogeneity}

Concerted evolution is a universal mechanism that was introduced to explain the pattern of gene evolution in which repetitive gene families evolve, in concert, as single homogenous units (Liao 1999). Selection would be expected to maintain the homogeneity of functional gene regions, but homogeneity in nonfunctional regions was unexpected because these regions are free to accumulate mutations by drift (Liao 1999; Nei \& Rooney 2005; Ganley \& Kobayashi 2007; Naidoo et al. 2013). This pertained to the intergenic or nonfunctional regions of repetitive gene families, which are more similar within a species than between two closely related species (Liao 1999; Eickbush \& Eickbush 2007).

During interphase, NORs converge in the nucleolus for rRNA gene transcription. Shared nucleolar localization brings homologous and non-homologous chromosomes in close proximity that may allow mitotic recombination events leading to homogenization of rRNA gene repeats. These opportunities allow much more frequent interactions within chromosomes than interactions between chromosomes that may be spatially separated (Seperak et al. 1988). Although VanKuren et al. (2013) showed rRNA gene variants in a Claroideoglomus spp. that cooccurred near each other within the same nucleoli were spatially separated. This organization would impair gene homogenization.

The project documented in this dissertation consisted of two studies, both of which involved comparison of species in two deeply rooted clades in Glomeromycota using spore morphology, spore development and mode of formation, and sequence data from a 700-725 bp region near the 5' end of the LSU gene. The first study (Chapter 2) compared eight species in Ambispora (Ambisporaceae) to test the null hypothesis that sufficient morphological and LSU divergence separated eight species in Ambispora and spore type (acaulosporoid, glomoid, or both) resolved species level separation. The second study (Chapter 3) compared the only two species in Archaeospora (Archaeosporaceae) to test the null hypothesis that differences in mode of spore formation from a sporiferous saccule and LSU divergence support identity of two discrete species in Archaeospora. 
Phylum: Glomeromycota Walker \& Schüßler

Class: Glomeromycetes Cavalier-Smith

Order: Diversisporales Walker \& Schüßler

Family: Diversisporaceae Walker \& Schüßler

Genus: Diversispora Walker \& Schüßler

Genus: Redeckera Walker \& Schüßler

Family: Acaulosporaceae Morton \& Benny

Genus: Acaulospora (Gerdemann \& Trappe) Berch

Family: Pacisporaceae C. Walker, Blaszkowski

Schüßler \& Schwarzott

Genus: Pacispora C. Oehl \& Sieverd.

Family: Gigasporaceae Morton \& Benny

Genus: Scutellospora Walker \& Sanders

Genus: Gigaspora (Gerdemann \& Trappe) Walker \& Sanders

Genus: Dentiscutata Oehl, Souza \& Sieverding

Genus: Cetraspora Oehl, Souza \& Sieverding

Genus: Racocetra Oehl, Souza \& Sieverding

Order: Glomerales Morton \& Benny

Family: Claroideoglomeraceae Walker \& Schüßler

Genus: Claroideoglomus Walker \& Schüßler

Family: Glomeraceae Pirozynski \& Dalphe

Genus: Glomus Tulasne \& Tulasne

Genus: Funneliformis Walker \& Schüßler

Genus: Septoglomus Sieverding, Silva \& Oehl

Genus: Rhizophagus (Dangeard) Walker \& Schüßler

Genus: Sclerocystis Berkeley \& Broome

Order: Archaeosporales Walker \& Schüßler

Family: Ambisporaceae Walker, Vestberg \& Schüßler

Genus: Ambispora Walker, Vestberg \& Schüßler

Family: Geosiphonaceae (Engler \& Gilg) Walker \& Schüßler

Genus: Geosiphon Wettstein

Family: Archaeosporaceae Morton \& Redecker

Genus: Archaeospora Morton \& Redecker

Order: Paraglomerales Walker \& Schüßler

Family: Paraglomeraceae Morton \& Benny

Genus: Paraglomus Morton \& Redecker

Fig 1 - Consensus classification of the phylum Glomeromycota down to genera based on rDNA phylogeny in Redecker et al. (2013). Taxa proposed by Goto et al. (2012) excluded. 


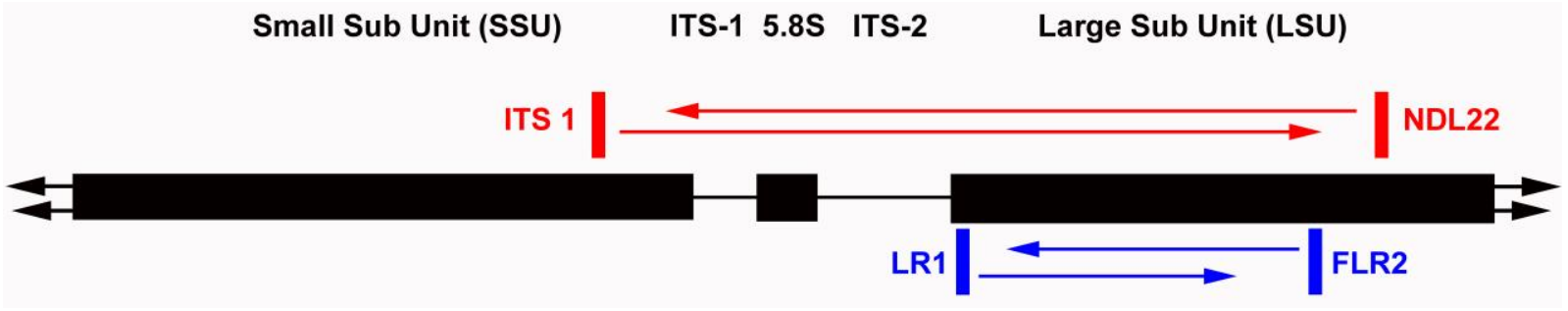

Fig 2 - Schematic representation of a partial single nuclear ribosomal RNA (rRNA) gene.

Primer arrows indicate the direction of amplification of each primer. Top red arrows indicate universal eukaryotic-species primers used in first round PCR amplification. Bottom blue arrows indicate fungus-specific primers used in second round PCR (White et al. 1998; van Tuinen et al. 1998b; Trouvelet et al, 1999). 


\section{References}

Allen MF, 1991. The Ecology of Mycorrhizae. Cambridge University Press, Cambridge, UK.

Antoninka AJ, Ritchie ME, Johnson NC, 2015. The hidden Serengeti-mycorrhizal fungi respond to environmental gradients. Pedobiologia. doi:10.1016/j.pedobi.2015.08.001.

Appoloni S, Lekberg Y, Tercek MT, Zabinski CA, Redecker D, 2008. Molecular community analysis of arbuscular mycorrhizal fungi in roots of geothermal soils in Yellowstone National Park (USA). Microbial Ecology 56: 649-659.

Augé RM, 2004. Arbuscular mycorrhizae and soil/plant water relations. Canadian Journal of Soil Science 84: 373-381.

Baum D, 1992. Phylogenetic species concepts. Tree 7: 1-2.

Baum DA, Smith SD, 2013. Tree Thinking: an introduction to phylogenetic biology. Roberts and Company. Greenwood Village, CO.

Bennett AE, Bever JD, 2007. Mycorrhizal species differentially alter plant growth and response to herbivory. Ecology 88: 210-218.

Bentivenga SP, Morton JB, 1995. A monograth of the genus Gigaspora, incorporating developmental patterns of morphological characters. Mycologia 87: 719-731.

Bills RJ, Morton JB, 2015. A combination of morphology and 28S rRNA gene sequences provide grouping and ranking criteria to merge eight into three Ambispora species (Ambisporaceae, Glomeromycota). Mycorrhiza 25: 485-498.

Buckler ES, Ippolito A, Holtsford TP, 1997. The evolution of ribosomal DNA: divergent paralogues and phylogenetic implications. Genetics 145: 821-832.

Corradi N, Croll D, Colard A, Kuhn G, Ehinger M, Sanders IR, 2007. Gene copy number polymorphisms in an arbuscular mycorrhizal fungal population. Applied and Environmental Microbiology 73: 366-369.

Corradi N, Kuhn G, Sanders IR, 2004a. Monophyly of b-tubulin and H+-ATPase gene variants in Glomus intraradices: consequences for molecular evolutionary studies of AM fungal genes. Fungal Genetics and Biology 41: 262-273. 
Corradi N, Hjiri M, Fumagalli L, Sanders IR, 2004b. Arbuscular mycorrhizal fungi (Glomeromycota) harbor ancient fungal tubulin genes that resemble those of the chytrids (Chytridiomycota). Fungal Genetics and Biology 41: 81-90.

Coyne JA, Orr HA, 2004. Speciation. Sinauer Associates, Sunderland, Massachusetts.

Cui M, Nobel PS, 1992. Nutrient status, water uptake and gas exchange for three desert succulents infected with mycorrhizal fungi. New Phytologist 122: 643-649.

Cracraft J, 1983. Species concepts and speciation analysis. Current Ornithology 1: 159-187.

Da Silva GA, Lumini E, Maia LC, Bonfante P, Bianciotto B, 2006. Phylogenetic analysis of Glomeromycota by partial LSU rDNA sequences. Mycorrhiza 16: 183-189.

Davis JI, 1996. Phylogenetics, molecular variation, and species concepts. BioScience 46: 502511.

Davis JI, Nixon KC, 1992. Populations, genetic variation, and the delimitation of phylogenetic species. Systematic Biology 41: 421-435.

Davison J, Moora M, Öpik M, Adholeya A, Ainsaar L, Bâ A, Burla S, Diedhiou AG, Hiiesalu I, Jairus T, Johnson NC, Kane A, Koorem K, Kochar M, Ndiaye C, Pärtel M, Reier Ü, Saks Ü, Singh R, Vasar M, Zobel M, 2015. Global assessment of arbuscular mycorrhizal fungus diversity reveals very low endemism. Science 349: 970-973.

De Pinna MGG, 1991. Concepts and tests of homology in the cladistic paradigm. Cladistics 7: 367-394.

De Queiroz K, 1988. Systematics and the Darwinian revolution. Philosophy of Science. 55: 238259.

Dez C, Tollervey D, 2004. Ribosome synthesis meets the cell cycle. Current Opinion in Cell Biology 7: 631-637.

Eickbush TH, Eickbush DG, 2007. Finely orchestrated movements: evolution of the ribosomal RNA genes. Genetics 175: 477-485.

Ereshefsky M, 1991. Species, higher taxa, and the units of evolution. Philosophy of Science 58: 84-101. 
Fatica A, Tollervey D, 2002. Making ribosomes. Current Opinion in Cell Biology 14: 313-318.

Fitter AH, 2005. Biodiversity and ecosystem function in soil. Functional Ecology 19: 369-377.

Franke M, Morton JB, 1994. Ontogenetic comparisons of arbuscular mycorrhizal fungi Scutellospora heterogama and Scutellospora pellucida: revision of taxonomic character concepts, species descriptions, and phylogenetic hypotheses. Canadian Journal of Botany 72: 122-134.

Fromont-Racine M, Senger B, Saveanu C, Fasiolo F, 2005. Ribosome assembly in eukaryotes. Gene 313: 17-42.

Ganley RD, Kobayashi T, 2007. Highly efficient concerted evolution in the ribosomal DNA repeats: total rDNA repeat variation revealed by whole genome sequence data. Cold Spring Harbor Laboratory Press 17: 184-191.

Gardes M, Bruns TD, 1993. ITS primers with enhanced specificity for basidiomycetesapplication to the identification of mycorrhizae and rusts. Molecular Ecology 2: 113-118.

Gianinazzi-Pearson V, Lemoine M-C, Arnould C, Gollotte A, Morton JB, 1994. Localiztion of $\beta$ (1-3) glucans in spore and hyphal walls of fungi in the Glomales. Mycologia 89: 478-485.

Gollette A, Van Tuinen D, Atkinson D, 2004. Diversity of arbuscular mycorhizal fungi colonizing roots of the grass species Agrostis capillaris and Lolium perenne in a field experiment. Mycorrhiza 14: 111-117.

Goto BT, da Silva GA, de Assis DM, Silva DKA, Souza RG, Ferreira ACA, Jobim K, Melo CMA, Viera HEE, Maia LC, Oehl F, 2012. Intraornatospora (Gigasporales), a new family with two new genera and two new species. Mycotaxon 119: 117-132.

Helgeson T, Daniell TJ, Husband R, Fitter AH, Young JPW, 1998. Ploughing up the world-wide web? Nature 394: 431.

Horvath CD, 1997. Discussion: phylogenetic species concept: pluralism, monism, history. Biology and Philosophy 12: 225-232.

International Culture Collection of (Vesicular) Arbuscular-Mycorrhizal Fungi. Species Descriptions from Reference Cultures. http://invam.caf.wvu.edu/fungi/taxonomy/speciesID.htm. James TY, Kauff F, Schoch CL, Matheny PB, Hofstetter V, et al., 2006. Reconstructing the early evolution of Fungi using a six-gene phylogeny. Nature 443: 818-822. 
Janos DP, 1980. Mycorrhizae influence tropical succession. Biotropica 12: 56-64.

Johnson NC, Tillman D, Wedin D, 1992. Plant and soil controls on mycorrhizal fungal communities. Ecology 73: 2034-2042.

Jany J, Pawlowska TE, 2010. Multinucleate spores contribute to evolutionary longevity of asexual Glomeromycota. The American Naturalist 175: 424-435.

Kaonongbua W, Morton JB, Bever JD, 2010. Taxonomic revision transferring species in Kuklospora to Acaulospora (Glomeromycota) and a description of Acaulospora colliculosa sp. nov. from field collected spores. Mycologia 102: 1497-1509. doi:10.3852/10-011.

Kelly CN, Morton JB, Cumming JR, 2005. Variation in aluminum resistance among arbuscular mycorrhizal fungi. Mycorrhiza 15: 193-201.

Kivlin SN, Hawkes CV, Treseder KK, 2011. Global diversity and distribution of arbuscular mycorrhizal fungi. Soil Biology and Biochemistry 43: 2294-2303.

Kjøller R, Røsendahl S, 2000. Detection of arbuscular mycorrhizal fungi (Glomales) in roots by nested PCR and SSCP (single stranded conformation polymorphism). Plant and Soil 226: 189196.

Kjøller R, Røsendahl S, 2001. Molecular diversity of glomalean (arbuscular mycorrhizal) fungi determined by distinct Glomus specific DNA sequences from roots of field grown peas. Mycological Research 105: 1027-1032.

Klugh KR, Cumming JR, 2007. Variation in organic acid exudation and aluminum resistance among arbuscular mycorrhizal species colonizing Liriodendron tulipifera. Tree Physiology 27: $1103-1112$.

Kohout P, Sudová R, Janoušková M, Čtvrtlíková M, Hejda M, Pánková H, Slavíková R, Štajerová K, Vosátka M, Sýkorová Z, 2013. Comparison of commonly used primer sets for evaluating arbuscular mycorrhizal fungal communities: is there a universal solution? Soil Biology and Biochemistry 68: 482-493.

Koide RT., 1991. Nutrient supply, nutrient demand and plant response to mycorrhizal infection. New Phytologist 117: 365-386.

Krüger M, Stockinger H, Krüger C, Schüßsler A, 2009. DNA-based species level detection of Glomeromycota: one PCR primer set for all arbuscular mycorrhizal fungi. New Phytologist 183: 212-223. 
Krüger M, Teste FP, Laliberte E, Lambers H, Coghlan M, Zemunik G, Bunce M, 2015. The rise and fall of arbuscular mycorrhizal fungal diversity during ecosystem retrogression. Molecular Ecology 24: 4912-4930.

Krüger M, Walker C, Schüßsler A, 2011. Acaulospora brasiliensis comb. nov. and Acaulospora alpina (Glomeromycota) from upland Scotland: morphology, molecular phylogeny and DNAbased detection in roots. Mycorrhiza 21: 577-587.

Lekberg, Y, Koide RT, Rohr JR, Aldrich-Wolfe L, Morton JB, 2007. Role of niche restrictions and dispersal in the composition of arbuscular mycorrhizal fungal communities. Journal of Ecology 95: 95-105.

Liao D, 1999. Concerted evolution: molecular mechanism and biological implications. American Journal of Human Genetics 64: 24-30.

Lloyd-Macgilp S, Chambers S, Dodd J, Fitter A, Walker C, Young J, 1996. Diversity of the ribosomal internal transcribed spacers within and among isolates of Glomus mosseae and related mycorrhizal fungi. New Phytologist 133: 103-111.

Mayr E, 1942. Systematics and the Origin of Species, From the Viewpoint of a Zoologist. Columbia University Press, New York.

Mishler BD, 1985. The morphological, developmental, and phylogenetic basis of species concepts in bryophytes. The Bryologist 88: 207-214.

Mishler BD, Theriot EC, 2000. A phylogenetic species concept: monophyly, apomorphy, and phylogenetic species concepts. In: Wheeler QD, Meier R (eds), Species Concepts and Phylogenetic Theory, a debate. Columbia University Press, New York, pp. 44-54.

Morton JB, 1988. Taxonomy of VA mycorrhizal fungi: classification, nomenclature, and identification. Mycotaxon 32: 267-324.

Morton JB, 1990. Evolutionary relationships among arbuscular mycorrhizal fungi in the endongonaceae. Mycologia 82: 192-207.

Morton JB, 1993. Problems and solutions for the integration of glomalean taxonomy, systematic biology, and the study of endomycorrhizal phenomena. Mycorrhiza 2: 97-109.

Morton JB, 1995. Taxonomic and phylogenetic divergence among five Scutellospora species based on comparative developmental sequences. Mycologia 87: 127-137. 
Morton JB, 2009. Reconciliation of conflicting phenotypic and rRNA gene phylogenies of fungi in glomeromycota based on underlying patterns and processes. In: Azcon-Aguilar C, Barea JM, Gianinazzi S, Gianinazzi-Pearson V (eds), Mycorrhizas - Functional Processes and Ecological Impact. Springer, Heidelberg, Germany, pp. 137-154.

Morton JB, Benny GL, 1990. Revised classification of arbuscular mycorrhizal fungi (Zygomycetes): a new order, Glomales, two new suborders, Glomineae and Gigasporineae, and two new families, Acaulosporaceae and Gigasporaceae, with an emendation of Glomaceae. Mycotoaxon 37: 471-491.

Morton JB, Redecker D, 2001. Two new families of Glomales, Archaeosporaceae and Paraglomaceae, with two new genera Archaeospora and Paraglomus, based on concordant molecular and morphological characters. Mycologia 93: 181-195.

Morton JB, Franke M, Cloud G, 1992. The nature of fungal species in Glomales (Zygomycetes). In: Read DJ, Lewis DH, Fitter A, Alexander I (eds), Mycorrhizas in Ecosystems CABI. University of Arizona Press, Tucson, Arizona, pp. 65-73.

Morton JB, Franke M, Bentivenga SP, 1995. Developmental foundations for morphological diversity among endomycorrhizal fungi in Glomales (Zygomycetes). In: Varma A, Hock B (eds), Mycorrhiza. Springer-Verlag, Berlin, pp. 669-683.

Morton JB, Msiska Z, 2010a. Ontogeny and phylogeny of a Scutellospora heterogama mutant, with implications for morphological recognition of species in Glomeromycota. Fungal Biology 114: $410-420$.

Morton JB, Msiska Z, 2010b. Phylogenies from genetic and morphological characters do not support a revision of Gigasporaceae (Glomeromycota) into four families and five genera. Mycorrhiza 20: 483-496. doi:10.1007/s00572-010-0303-9.

Morton JB, Redecker D, 2001. Two new families of Glomales, Archaeosporaceae and Paraglomeraceae, with two new genera Archaeospora and Paraglomus, based on concordant molecular and morphological characters. Mycologia 93: 181-195.

Msiska Z, Morton JB, 2009a. Isolation and sequence analysis of a $\beta$-tubulin gene from arbuscular mycorrhizal fungi. Mycorrhiza 19: 501-513.

Msiska Z, Morton JB, 2009b. Phylogenetic analysis of the Glomeromycota by partial $\beta$-tubulin gene sequences. Mycorrhiza 19: 247-254. 
Naidoo K, Steenkamp ET, Coetzee MPA, Wingfield MJ, Wingfield BD, 2013. Concerted evolution in the ribosomal RNA cistron. PLoS One 8: 1-8 .doi:10.1371/journal.pone.0059355.

Nei M, Rooney AP, 2005. Concerted and birth-and-death evolution of multigene families. Annual Review of Genetics 39: 121-152.

Newsham KK, Fitter AH, Watkinson AR, 1995. Arbuscular mycorrhizal protect an annual grass from root pathogenic fungi in the field. Journal of Ecology 83: 991-1000.

Oehl F, Sieverding E, Palenzuela J, Ineichen K, da Silva GA, 2011. Advances in Glomeromycota taxonomy and classification. IMA Fungus 2: 191-199.

Olsen GJ, Woese CR, 1993. Ribosomal RNA: a key to phylogeny. Federation of American Societies for Experimental Biology 7: 113-123.

Olson MOJ, Dundr M, 2005. The moving parts of the nucleolus. Histochemistry and Cell Biology 123: 203-216.

Öpik M, Davison J, Moora Mara, Zobel M, 2014. DNA-based detection and identification of Glomeromycota: the virtual taxonomy of environmental sequences. Botany 92: 135-147.

Öpik M, Moora M, Liira J, Zobel M, 2006. Composition of root-colonizing arbuscular mycorrhizal fungal communities in different ecosystems around the globe. Journal of Ecology 94: 778-790.

Öpik M, Mertsis M, Daniell TJ, Zobel M, Moora M, 2009. Large-scale parallel 454 sequencing reveals host ecological group specificity of arbuscular mycorrhizal fungi in a boreonemoral forest. New Phytologist 184: 424-437.

Patterson C, 1982. Morphological characters and homology. In: Joysey KA, Friday AE (eds), Problems of Phylogenetic Reconstruction. Academic Press, London, pp. 21-74.

Patterson C, 1988. Homology in classical and molecular biology. Molecular Biology and Evolution 5: 603-625.

Pirozynski KA, Mallach DW, 1975. Origin of land plants - matter of mycotropism. Biosystems 6: $153-164$.

Raška I, Shaw PJ, Cmarko D, 2006. New insights to the nucleolar architecture and activity. International Review of Cytology 255: 177-235. 
Reddy SR, Pindi PK, Reddy SM, 2005. Molecular methods for research on arbuscular mycorrhizal fungi in India: problems and prospects. Current Science 89: 1699-1709.

Redecker D, 2000. Specific primers to identify arbuscular mycorrhizal fungi within colonized roots. Mycorrhiza 10: 73-80.

Redecker D, 2002. Molecular identification and phylogeny of arbuscular mycorrhizal fungi. Plant and Soil 244: 67-73.

Redecker D, Kodner R, Graham LE, 2000. Glomalean fungi from the Ordovician. Science 289: 1920-1921.

Redecker D, Morton JB, Bruns TD, 2000. Ancestral lineages of arbuscular mycorrhizal fungi (Glomales). Molecular Phylogenetics and Evolution 14: 276-284.

Redecker D, Hijri I, Wiemken A, 2003. Molecular identification of arbuscular mycorrhizal fungi in roots: perspectives and problems. Golia Geobotanica 3: 113-124.

Redecker D, Raab P, 2006. Phylogeny of the Glomeromycota (arbuscular mycorrhizal fungi): recent developments and new gene markers. Mycologia 98: 885-895.

Redecker D, Schüßler A, Stockinger H, Stürmer SL, Morton JB, Walker C, 2013. An evidencebased consensus for the classification of arbuscular mycorrhizal fungi (Glomeromycota).

Mycorrhiza 23: 515-531. doi:0.1007/s00572-013-0486-y.

Remy W, Taylor TN, Hass H, Kerp H, 1994. Four hundred-million-year-old vesicular arbuscular mycorrhizae. PNAS 91: 11841-11843.

Rodriguez A, Clapp JP, Robinson L, Dodd JC, 2005. Studies on the diversity of the distinct phylogenetic lineage encompassing Glomus claroideum and Glomus etunicatum. Mycorrhiza 15: 33-46.

Røsendahl S, 2007. Communities, populations and individuals of arbuscular mycorrhizal fungi. New Phytologist 178: 253-266.

Sanders IR, Alt M, Groppe K, Boller T, Wiemken A, 1995. Identification of ribosomal DNA polymorphisms among and within spores of the Glomales: application to studies on the genetic diversity of arbuscular mycorrhizal fungal communities. New Phytologist 130: 419-427. 
Sawaki H, Sugawara K, Saito M, 1998. Phylogenetic position of arbuscular mycorrhizal fungus, Acaulospora gerdemannii, and its synanamorph Glomus leptotichum, based upon 18S rRNA gene sequence. Mycoscience 39: 477-480.

Schenck NC, Spain JL, Sieverding E, Howeler RH, 1984. Several new and unreported vesiculararbuscular mycorrhizal fungi (Endogonaceae) from Columbia. Mycologia 76: 685-699.

Schüßler A, 2002. Molecular phylogeny, taxonomy, and evolution of Geosiphon pyriformis and arbuscular mycorrhizal fungi. Plant and Soil 244: 75-83.

Schüßler A, Schwarzott D, Walker C, 2001. A new fungal phylum, the Glomeromycota: phylogeny and evolution. Mycological Research 105: 1413-1421.

Schüßler A, Walker C, 2010. The Glomeromycota: a species list with new families and new genera. Arthur Schüßler \& Christopher Walker, Gloucester. Published in December 2010 in libraries at The Royal Botanic Garden Edinburgh, The Royal Botanic Garden Kew, Botanishce Staatssammlung Munich, and Oregon State University. Printed copy available under ISBN-13: 978-1466388048, ISBN-10: 1466388048. Available at http://www.amf-phylogeny.com. Seperack P, Slatkin M, Arhehim N, 1988. Linkage disequilibrium in human ribosaoma genes: implications for multigene family evolution. Genetics 119: 943-949.

Simon L, Lalonde M, Bruns TD, 1992. Specific amplification of 18S fungal ribosomal genes from vesicular-mycorrhizal fungi colonizing roots. Applied and Environmental Microbiology 58: 291-295.

Smith SE, Read DJ, 2008. Mycorrhizal symbiosis, $3^{\text {rd }}$ edn. Academic Press, New York.

Sogin ML, 1990. Amplification of ribosomal RNA genes for molecular evolution studies. In: Innis MA, Gelfand DH, Sninksy JJ, White JW (eds), PCR Protocols: a guide to methods and applications. Academic Press Inc, San Diego, California, pp. 307-314.

Sonnenberg R, Nolte AW, Tautz D, 2007. An evaluation of LSU rDNA D1-D2 sequences for their use in species identification. Frontiers in Zoology 4: 1-12.

Stockinger S, Krüger M, Krüger M, Schüßsler A, 2010. DNA barcoding of arbuscular mycorrhizal fungi. New Phytologist 187: 461-474.

Stockinger H, Peyret-Guzzon M, Koegel S, Bouffaud M-L, Redecker D, 2014. The largest subunit of RNA polymerase II as a new marker gene to study assemblages of arbuscular mycorrhizal fungi in the field. PLOS One 9. DOI: e107783. 
Stukenbrock EH, Røsendahl S, 2005. Development and amplification of multiple co-dominant genetic markers from single spores of arbuscular mycorrhizal fungi by nested multiplex PCR. Fungal Genetics and Biology 42: 73-80.

Stuessy TF, 1992. The systematics of arbuscular mycorrhizal fungi in relation to current approaches to biological classification. Mycorrhiza 1: 113-121.

Stürmer SL, Morton JB, 1997. Developmental patterns defining morphological characters in spores of four species in Glomus. Mycologia 89: 72-81

Stürmer SL, Morton JB, 1999. Taxonomic reinterpretation of morphological characters in Acaulosporaceae based on developmental patterns. Mycologia 91: 849-857.

Stutz JC, Copeman R, Martin CA, Morton JB, 2000. Patterns of species composition and distribution of arbuscular mycorrhizal fungi in arid regions of southwestern North America and Namibia, Africa. Canadian Journal of Botany 78: 237-245.

Toler HD, Morton JD, Cumming JR, 2005. Growth and metal accumulation of mycorrhizal sorghum exposed to elevated copper and zinc. Water, Air and Soil Pollution 164: 155-172.

van der Heijden MGA, Klironomos JN, Ursic M, Moutoglis P, Streitwolf-Engel R, Boller T, Wiemken A, Sanders IR, 1998. Muycorrhizal fungal diversity determines plant biodiversity, ecosystem variability and productivity. Nature 396: 69-72.

VanKuren NW, den Bakker HC, Morton JB, Pawlowska TE, 2013. Ribosomal RNA gene diversity, effective population size, and evolutionary longevity in asexual Glomeromycota. Evolution 67: 207-224.

Van Tuinen D, Jacquot E, Zhao B, Gollette A, Gianinazzi-Pearson V, 1998a. Characterization of root colonization profiles by a microcosm community of arbuscular mycorrhizal fungi using $25 \mathrm{~S}$ rDNA-targeted nested PCR. Molecular Ecology 7: 879-887.

Van Tuinen D, Zhao B, Gianinazzi-Pearson V, 1998b. PCR in studies of AM fungi: from primers to application. In: Varma A (ed), Mycorrhiza Manual. Springer-Verlag, Berlin, pp. 337399.

Vogelsang KM, Reynolds HL, Bever JD, 2006. Mycorrhizal fungal identity and richness determine the diversity and productivity of a tallgrass prairie system. New Phytologist 172: 554562. 
Walker C, 1983. Taxonomic concepts in the Endogonaceae: spore wall characteristics in species descriptions. Mycotaxon 18: 443-455.

Walker C, Schüßler A, 2004. Nomenclatural clarifications and new taxa in the Glomeromycota. Mycological Research 108: 981-982.

White TJ, Bruns T, Lee S, Taylor J, 1990. Amplification and direct sequencing of fungal ribosomal RNA genes for phylogenetics. In: Innis MA, Gelfand DH, Sninksy JJ, White JW (eds), PCR Protocols: a guide to methods and applications. Academic Press Inc, San Diego, California, pp. 315-322. 


\section{CHAPTER 2}

\section{A COMBINATION OF MORPHOLOGY AND 28S RRNA GENE SEQUENCES PROVIDE GROUPING AND RANKING CRITERIA TO MERGE EIGHT INTO THREE AMBISPORA SPECIES (AMBISPORACEAE, GLOMEROMYCOTA) ${ }^{1}$}

\section{Introduction}

Classification of arbuscular mycorrhizal fungi in the phylum Glomeromycota has undergone numerous changes during the past decade as application of sequence data from ribosomal RNA and beta-tubulin genes together with some input from morphology inferred more natural phylogenetic relationships (Redecker and Raab 2006; Msiska and Morton 2009; Oehl et al. 2011; Krüger et al. 2012; Redecker et al. 2013). Some clades were well resolved and highly supported by both morphological and molecular data, so they evoked little controversy. Others were more problematic because of conflicts between traditional morphological characters and rDNA sequence data. Fungal species in the order Archaeosporales (Schüßler et al. 2001) exemplify some of these problems and the difficulties in resolving them. Dimorphic species, with spore phenotypes bridging two families, created nomenclatural and phylogenetic confusion.

Complicating this story were misleading interpretations of degraded type specimens and treating any perceived difference as a species-defining character. Also, use of molecular data to provide independent verification of morphological interpretations was not possible for species lacking living material.

Archaeosporales presently consists of three monogeneric families. Geosiphonaceae contains one nonmycorrhizal species Geosiphon pyriformis (Schüßler et al. 2001; Schüßler 2002). Archaeosporaceae consists of Archaeospora trappei (Morton and Redecker 2001), described first as Acaulospora trappei (Ames and Linderman 1976) and Archaeospora schenckii (Krüger et al. 2012), described initially as Entrophospora schenckii (Sieverding and Toro 1987). Ambisporaceae contains eight species in the genus Ambispora (Walker et al. 2007a; Walker 2008) and this group is the focus of this study. The nomenclatural history of species in Ambispora is summarized in Fig. 1 to clarify events in a complex timeline.

\footnotetext{
${ }^{1}$ Published as Bills RB, Morton JB. 2015. Mycorrhiza 25: 485-498. doi: 10.1007/s00572-015-0626-7.
} 
Species in Ambispora were classified initially by mode of spore formation. Species forming glomoid spores with a subtending hypha were placed in Glomus and species with acaulosporoid spores attached to a terminal saccule were placed in Acaulospora (Gerdemann and Trappe 1974). Protologue descriptions of Acaulospora gerdemannii (Nicolson and Schenck 1979), Glomus leptotichum (Schenck and Smith 1982) and Glomus fecundisporum (Schenck and Smith 1982) were based on only one spore morphotype. Acaulospora appendicula (Schenck et al. 1984) also was described as monomorphic even though glomoid spores, described as being chlamydosporelike, were mentioned in the protologue. In strains deposited in the International Culture Collection of Vesicular Mycorrhizal Fungi (INVAM) by N.C. Schenck, glomoid and acaulosporoid spores of Acaulospora appendicula FL130A were indistinguishable from those in a dimorphic culture of G. leptotichum FL184B propagated from a single spore of each spore type (Morton et al. 1997). Examination of Oregon State University Herbarium (OSC) holotype and University of Florida (FLAS) isotype specimens revealed a similar result. Morton et al. (1997) then synonymized both Acaulospora and both Glomus species into a dimorphic species classified as Acaulospora gerdemannii to satisfy the criterion of nomenclatural priority. 18S rRNA gene (SSU) sequences verified dimorphism and also showed this species was basal to most other glomeromycotan clades (Sawaki et al. 1998; Redecker et al. 2000).

Rose et al. (1979) described Glomus gerdemannii from field-collected spores that were interpreted as possessing glomoid features. Similar novel ornamentations of spore wall layers and subtending hypha were observed on acaulosporoid spores of a dimorphic culture of INVAM accession AU215. This fungus also formed smaller glomoid spores that were phenotypically similar to those of G. leptotichum and type specimens of G. fecundisporum (Morton and Redecker 2001). A small sampling of SSU sequences grouped this species with Ac. gerdemannii (Redecker et al. 2000).

Analysis of SSU sequences also showed that Ac. trappei was more closely related to the two dimorphic species than to other Acaulospora species and so Morton and Redecker (2001) placed all three species in a new genus Archaeospora and in a new family Archaeosporaceae. Since G. gerdemannii and Ac. gerdemannii shared a common specific epithet, the former was renamed Archaeospora gerdemannii and the latter Archaeospora leptoticha.

Schüßler et al. (2001) used a broader sampling of SSU sequences that included the nonmycorrhizal species Geosiphon pyriformis to resolve three distinct monophyletic clades. 
Geosiphon was placed in its own family, Geosiphonaceae in a new order Archaeosporales. The dimorphic species (Ar. leptoticha and Ar. gerdemannii) grouped into one clade and Ar. trappei into another. Spain et al. (2006) focused on the dimorphic clade and placed them in a new genus, Appendicispora. At the same time, these workers reversed all four synonymizations by Morton et al. (1997) based on their interpretations of morphological evidence. The dimorphic Ar. leptoticha was synonymized as the monomorphic Glomus leptotichum, and Ac. appendicula was resurrected as the dimorphic species Appendicispora appendicula. Acaulospora gerdemannii was restored as a monomorphic acaulosporoid species and renamed Appendicispora jimgerdemannii. Glomus fecundisporum was resurrected based on perceived differences in type specimens (spore wall outer layer). The dimorphic species Ar. gerdemannii was renamed Appendicispora gerdemannii.

Independently, Walker et al. (2007a) erected a new genus Ambispora typified by Ambispora fennica, a dimorphic fungus with SSU and ITS sequences that diverged from those of the other dimorphic species. The acaulosporoid spore was of similar phenotype to that of Ar. gerdemannii, but a single, short SSU and an ITS sequence of Ar. gerdemannii published by Redecker et al. (2000) did not cluster with Am. fennica sequences. These data, then, were used to discriminate the latter as a distinct species. They also transferred Glomus callosum (Sieverding 1988) to Ambispora callosa, relying on two glomoid strains from Japan (OK1, MAFF520057 and V1, MAFF520058) annotated as G. leptotichum in the National Institute of Agricultural Sciences (NIAS) Genebank databases (Murakoshi et al. 1998, Saito 2001, Kojima et al. 2004). ITS sequence divergence was used as the basis for separating Am. callosa from Am. leptoticha.

Two publications with classifications involving the same taxa (Spain et al. 2006; Walker et al. 2007a) created a confusing nomenclature. Walker et al. (2007b) resolved this problem by assigning priority to Appendicispora, erecting a new family Appendicisporaceae, and transferring all Ambispora species to this genus. Appendicispora was determined later to be a homonym, so Ambispora was resurrected and Appendicisporaceae was synonymized with a new family Ambisporaceae (Walker 2008). Palenzuela et al. (2011) then described a new dimorphic species, Ambispora granatensis, based on a combination of morphological and SSU and ITS sequence data. In this study, both comparative morphology and sequences of a 700-750 bp region of the $5^{\prime}$ end of the $28 \mathrm{~S}$ rRNA (LSU) gene were used to reexamine the eight species currently circumscribed in Ambispora (Fig. 1). Ambispora reticulata has been added more 
recently (Oehl et al. 2012), but its taxonomic status will be discussed in a separate analysis because there is no evidence it is even a mycorrhizal fungus.

\section{Materials and methods}

Specimens

Type materials of Ambispora species consisted of Ac. appendicula (OSC 41495, FLAS F53673); Ac. gerdemannii (OSC 37514, FLAS F51804); Am. fennica (EPITYPE Att550-30 from M. Vestberg); Gl. fecundisporum (OSC 40250, FLAS F52579); Gl. gerdemannii (OSC 39476); and Gl. leptotichum (OSC 40249, FLAS F52577). Spores of G. callosum (OSC 147148) preserved in $5 \%$ formalin were used for morphological analyses. Only slide vouchers were available for analysis of Am. granatensis (OSC 134712, Z+ZT 1626).

Ambispora leptoticha strains consisted of INVAM accessions used by Morton et al. (1997) and Morton and Redecker (2001) for comparison with type specimens of Ac. appendicula, Ac. gerdemannii, Gl. fecundisporum and Gl. leptotichum. Living cultures included FL130A, FL184B, MX982A, NC169, NC171, NC176, WV109C and VZ856B. Accessions FL184B and FL130A were identified as reference strains for G. leptotichum and Ac. appendicula, respectively, because both were deposited by N.C. Schenck, an author of both protologues. They were not designated here as ex-types because provenance with the type pot cultures could not be established unequivocally. Cultures of Ambispora gerdemannii strains consisted of INVAM accessions MT106 and ON205A. The reference strain for Am. gerdemannii AU215A used by Redecker et al. (2000) and Morton and Redecker (2001) died before this study began, so only slide vouchers were available for morphological reevaluation.

The plant host used to culture all fungi was Sorghum sudanense (Staph.) Piper, according to protocols described by Morton et al. (1993). Voucher specimens consisted of spores from each culture mounted permanently on glass slides in polyvinyl alcohol-lactic acid-glycerol (PVLG, Koske and Tessier 1983) and PVLG mixed with Melzer's reagent (1:1 v/v). Specimens were examined with a Nikon Eclipse E600 microscope and photographed with a Nikon DS-Ri1 digital camera. All slides are stored in the INVAM voucher library. 
DNA extraction.

DNA was extracted from single spores of Am. leptoticha and Am. gerdemannii crushed in a 0.2 $\mathrm{mL}$ microcentrifuge tube containing $14 \mu \mathrm{L} 10 \mathrm{X}$ Taq polymerase buffer (New England Biolabs, Ipswich, MA) with a UV sterilized micro pestle. Tube contents were transferred to $94{ }^{\circ} \mathrm{C}$ water bath for 4 min, snap-chilled and stored on ice until amplification.

Two rounds of PCR amplification were performed to generate enough product of the LSU gene. For the first round of amplification, primer pair ITS1 and NDL22 was used, followed by a nested amplification using primers LR1 and FLR2 (White et al. 1990, van Tuinen et al. 1998, Trouvelet et al. 1999). PCR was performed in $50 \mu \mathrm{L}$ volumes containing $4 \mu \mathrm{L}$ spore DNA, $3 \mu \mathrm{L}$ 10x PCR buffer (New England BioLabs, Ipswich, MA), $0.2 \mathrm{mmol}$ of each dNTP, $1.5 \mathrm{mmol}$ $\mathrm{MgCl}_{2}, 5 \mathrm{pmol}$ of each primer, and $0.1 \mu \mathrm{L}$ of Taq DNA polymerase (New England BioLabs, Ipswich, MA). The second round of PCR was similar to the first but used $1.0 \mu \mathrm{L}$ of first amplification product as template with $7 \mu \mathrm{L} 10 \mathrm{x}$ PCR buffer. Cycling parameters for both rounds of amplification entailed initial denaturation at $94{ }^{\circ} \mathrm{C}$ for $4 \mathrm{~min}, 30$ cycles at $94{ }^{\circ} \mathrm{C}$ for $30 \mathrm{~s}$, annealing at $58{ }^{\circ} \mathrm{C}$ for $1 \mathrm{~min}$, extension at $72{ }^{\circ} \mathrm{C}$ for $1 \mathrm{~min}$, and a final extension at $72{ }^{\circ} \mathrm{C}$ for 10 min. PCR products $(8 \mu \mathrm{L})$ were stained with ethidium bromide and electrophoresed on a $1.5 \%$ agarose gel and visualized by UV illumination. Amplification products were purified with QIAquick PCR Purification kit (Qiagen USA, Valencia, CA) and cloned with pCR®4-TOPO plasmid vector and transformed using One Shot@ TOP10 chemically competent cells (Invitrogen, Carlsbad, CA). Positive transformants were verified with colony PCR using LR1/FLR2 primers. Colony PCR reactions were performed in $12.5 \mu \mathrm{L}$ containing $1 / 4$ volume of PCR reagents, transformants sampled by pipette tip in $5.93 \mu \mathrm{L}$ nuclease free water, and $0.1 \mu \mathrm{L}$ of Taq DNA polymerase. Cycling parameters were identical to regular PCR. Plasmid DNA containing the insert was purified using QIAprep Miniprep kit and DNA sequenced at Davis Sequencing (Davis, CA, USA) using M13 primers. New LSU sequences were deposited in NCBI as accession numbers KC166251-KC166283. Sequence alignment is available at INVAM (http://invam.wvu.edu/). Published LSU sequences of Am. appendicula and Am. fennica were obtained from the National Center for Biotechnology Information (NCBI) database. 
Phylogenetic analyses

Sequence chromatographs were inspected in Biological Sequence Alignment Editor (BioEdit, www.mbio.ncsu.edu/BioEdit/bioedit.html) and subjected to a search on the NCBI nucleotide Basic Local Alignment Search Tool (nBLAST) to verify homology with other glomeromycotan fungal sequences. Nucleotide sequences were aligned using MUSCLE (Edgar 2004).

Phylogenetic trees were inferred from Bayesian analysis in MrBayes 3.2.2 (Ronquist et al. 2011, http://mrbayes.net) and maximum likelihood (ML) criteria implemented in MEGA6 (Tamura et al. 2013). Model test for 24 different nucleotide substitution models was performed in MEGA6 (Tamura et al. 2013). Kimura 2-parameter model plus gamma (K2P+G) had the lowest Bayesian Inference Criterion (BIC) score and was selected for analyses (Nei \& Kumar 2000). MrBayes settings were 4 x 4 nucleotide model, general time-reversible (GTR) converted to K2P by fixing stationary state frequencies to equal and ploidy set to haploid. The analysis included two runs of 10,000,000 generations with burn-in of 2,500,000 generations. The Bayesian tree was visualized in FigTree v1.3.1 (http://tree.bio.ed.ac.uk/software/figtree). ML analysis was performed in MEGA6 with K2P + G model, with four discrete gamma categories and 1000 replications to assess bootstrap support (Tamura et al. 2013).

\section{Results}

Molecular analysis

Bayesian and ML analyses of LSU sequences analyses grouped acaulosporoid and glomoid spores of Am. leptoticha and Am. appendicula strains in a highly supported monophyletic clade, thus providing evidence of conspecificity (Fig. 2). In the absence of living source material, LSU sequences could not be obtained from G. fecundisporum, Am. callosa, or Am. granatensis.

LSU sequences from the one representative strain of Am. fennica grouped with those of two North American strains of Am. gerdemannii in a highly supported clade (Fig. 2), but they also formed a distinct subclade. When equivalence in branching pattern and sequence variation within sister clades was used as the criterion to determine rank at the molecular level (Redecker et al. 2013), then Am. fennica and Am. gerdemannii were conspecific. A third-party LSU sequence of Gl. gerdemannii AU215 (GenBank accession AJ510233) grouped with Am. leptoticha, verifying that this sequence was annotated incorrectly when it was submitted to NCBI (Kaonongbua et al. 2010). 
Morphological analyses

All of the Ambispora species described in this paper are potentially dimorphic, and each spore type exhibits unique patterns of morphological divergence and hence taxonomic significance. Holotype and isotype specimens of many species were parasitized or degraded in a lactophenol storage medium, thus altering color and dimensions of spore wall layers of many specimens. However, important diagnostic features still were identifiable from some specimens for comparative purposes. Range of spore diameters has been reviewed elsewhere (Walker et al. 2007a and references therein).

\section{Glomoid spores}

Glomoid type specimens (Fig. 3a-b) and reference culture G. leptotichum FL184B (Fig. 3c-d) were indistinguishable from those of G. fecundisporum (Figs. 3e), Ac. gerdemannii (Fig. 3f-g), Ac. appendicula (Fig. 3h), Am. gerdemannii (Fig. 3i-j) and Am. granatensis (Fig. 3k-1). Glomoid spores of all Ambispora species described to date, whether examined as type or fresh specimens, possessed a similar bilayered spore wall continuous with a bilayered subtending hyphal wall (Figs. 3-4). The outer layer (L1) often thins with age and then appears granular, flaky, or is absent after sloughing. An "alveolate reticulum" of shallow ridges rarely was observed on the surface of the spore wall outer layer of G. leptotichum (Fig. 3a-b), a trait used by Schenck and Smith (1982) and Spain et al. (2006) to distinguish this species from G. fecundisporum (Fig. 3e). The spore wall inner layer (L2) is permanent and is semi-pliable even in preserved specimens because it changes shape with applied pressure in all species and sometimes has a wrinkled inner surface, all of which likely contribute to the observed phenotypic variability. Spores also varied in degree of browning, (Fig. 3e, f-g) which is likely an artifact because spores were hyaline to pale yellow in all healthy living cultures. Glomoid spores from Am. gerdemannii MT106 and those from isotype specimens of Am. granatensis were indistinguishable from glomoid spores of other Ambispora species except they were smaller and thus had thinner spore wall layers (Fig. 3i1). The wide range in spore size observed in a culture of G. leptotichum FL184B (50-280 $\mu \mathrm{m})$ also was found in vials of glomoid type specimens of G. leptotichum, G. fecundisporum, Ac. gerdemannii, and Ac. appendicula. Glomoid spores of an Am. granatensis in pot culture 
(Paluenza et al. 2011) have a smaller size range $(40-70 \mu \mathrm{m})$ than that of Am. gerdemannii MT106/ON205A (40-190 $\mu \mathrm{m})$, which overlaps the size range of Am. leptoticha spores.

Glomus callosum was reclassified as Ambispora callosa because of SSU relatedness and ITS clade structure (Walker et al. 2007a). Glomoid spores of holotype G. callosum (Fig. 4a-c) did not possess any traits that distinguished this species from fresh spores of G. leptotichum FL184B (Fig. 4d-f), even though type spores had been preserved in 5\% formalin for 15 years. The range in spore size overlapped between species and all were within the range reported by Walker et al. (2007a). As with other Ambispora species (Fig. 3), the hyaline to pale yellow spore wall of both species was bilayered, with a somewhat friable outer layer and a thicker semi-pliable inner layer (Fig. 4b-c, e-f). In particular, the continuity of bilayered organization in spore and attached hyphal walls was a consistent phenotype shared among glomoid spores of all species in Ambispora. The absence of distinctive morphological traits renders this spore synanamorph taxonomically uninformative below the rank of genus.

\section{Acaulosporoid spores}

All Ambispora species form a glomoid-like subtending hypha (pedicel) that branches from the neck of a sporiferous saccule, hence the term "acaulosporoid" (Fig. 5a-b). The spore wall in all taxa consists of three discrete layers and a developmentally separate semi-pliable hyaline inner wall (Fig. 5a-c). Only the two inner layers of the spore wall (L2-L3) diverge as discrete and stable phenotypes, and so they are the taxonomically significant morphological traits at the species level. The L2 and L3 layers of the spore wall form hemispherical protrusions and depressions, respectively, in Am. leptoticha (Fig. 5a). Both layers are smooth and rigid, but L3 is brittle and breaks into shards that are birefringent in polarized light when crushed in $A m$. gerdemannii (Fig. 5b). Both L2 and L3 are rigid, but L2 is quite thin $(<2 \mu \mathrm{m})$ with a faintly wrinkled surface in Am. granatensis (Fig. 5c). All other characters vary somewhat, but much of that variation is encompassed within and between strains of any given species. The semi-flexible hyaline inner wall is indistinguishable between species (Fig. 5a-c).

Some overlapping traits have been used erroneously to separate species. Spain et al. (2006) distinguished Ac. gerdemannii (reclassified as Am. jimgerdemannii) from Ac. appendicula (reclassified as Am. appendicula) based solely on two phenotypes of the outer spore wall layer that tend to degrade and slough readily (Fig. 6a): (i) "cerebriform" folds consisting of prominent 
ridges that resembled convolutions of a mammalian brain (e.g. Fig. 6b) and (ii) a "crazed" surface consisting of fine friable cracks and fissures that easily crumbled (e.g. Fig. 6c). The cerebriform phenotype documented in the protologue and type specimens of Am. jimgerdemannii (Fig. 6b) also was found on spores from Ac. appendicula FL130A (Fig. 6d) and G. leptotichum FL184B. From a population of spores in active culture FL130A (Fig. 6f), phenotypes from crazed to cerebriform phenotypes were present in a continuum (Fig. d-f). The crazed phenotype used to distinguish Ac. appendicula also predominated in fresh spores extracted from a culture of Am. leptoticha WV109. Moreover, the same continuum of phenotypes chronicled above for FL130A also was present in this pot culture. Clearly, the character states of the outer layer of the spore wall can co-occur as a range of phenotypes because of friability and susceptibility to decomposition. Even absence of the outer two layers of the acaulosporoid spore wall (Fig. 6a) is not unusual because it has been observed in all 19 INVAM accessions of Am. leptoticha. Since these character states are neither stable nor consistent, they are taxonomically uninformative at any level.

Spore morphology is indistinguishable between Am. fennica, Am. gerdemannii, and the holotype of G. gerdemannii when population level variation, age, degradation and preservation artifacts are taken into account (Fig. 7). The acaulosporoid spore of all three of these species consists of a three-layered spore wall and a semi-pliable inner wall of separate origin during development (Morton and Redecker 2001). The outer two layers of the spore wall in specimens of both Am. fennica (Fig. 7a-c) and Am. gerdemannii MT106 (Fig. 7d-f) are adherent and friable, breaking apart readily when crushed, and produce a dark dextrinoid staining reaction in Melzer's reagent. These two layers vary greatly in appearance depending on degree of degradation or sloughing and can be partly to mostly sloughed or absent in some spores. The inner layer of the spore wall (L3) is novel, with a fracture pattern that can produce sharp-edged shards that are birefringent in polarized light. The thick semi-pliable inner hyaline wall may appear as only one layer, but sometimes separates into a number of very thin layers on either or both proximal and distal surfaces (Fig. 7c, f).

Analysis of type specimens and phylogenetic analysis by Palenzuela et al. (2011) support Am. granatensis as a discrete species in the Ambispora. No LSU sequences were available for analysis of Ambispora granatensis in this study, but SSU phylogeny positions this species as a monophyletic clade in the genus (Palenzuela et al. 2011; Krüger et al. 2012). Phylogenetic tree 
branch lengths reported in their analysis suggests greater sequence variation than has been measured in other Ambispora species. Type material verified that Am. granatensis is a dimorphic species with both glomoid spore types (Fig. 3k, 1) of similar morphology to those produced by Am. leptoticha and Am. gerdemannii and is unique in phenotypes of the L2 and L3 layers of the acaulosporoid spore wall (Fig. 5c).

\section{Revised classification}

Ambisporaceae C. Walker, Vestberg \& Schüßler emend. R.J. Bills \& J.B. Morton

Synonym: Appendicisporaceae C. Walker, Vestberg \& Schüßler, Mycol. Res. 111:254 (2007); nom. illegit. (Arts 53.1, 53.3)

Typus: Ambispora (C. Walker, Vestberg \& Schüßler) R.J. Bills \& J.B. Morton 2013

Arbuscular mycorrhizal fungi producing dimorphic propagules of both glomoid and acaulosporoid spores, although fungal genotypes and environment impact on expression of either or both spore types. Spores formed singly or in clusters, from the terminal tip of a sporiferous hypha (glomoid synanamorph) or subtending an acaulosporoid spore (acaulosporoid synanamorph). Glomoid spores are hyaline with bilayered spore and hyphal walls lacking any discrete species-level characters. Acaulosporoid spores formed from a pedicel branching from the neck of a hyaline sporiferous saccule. Acaulosporoid spores possess a three-layered spore wall and a separate semi-pliable hyaline inner wall with layers of variable number and thickness. Spore wall outer layer tends to degrade and slough with age and the middle and inner layers of the spore wall express unique phenotypes that differentiate species. Distinguished from other families in the Archaeosporales by potential dimorphism, unique acaulosporoid spore morphology, and monophyly derived from rDNA sequence variation.

Ambispora C. Walker, Vestberg \& Schüßler emend. R. Bills \& J.B. Morton Type species: Ambispora gerdemannii (S.L. Rose, B.A. Daniels \& Trappe) R. Bills \& J.B. Morton, comb. nov. 
Dimorphic arbuscular mycorrhizal fungi capable of producing either or both glomoid and acaulosporoid spores. Glomoid spores hyaline with bilayered spore and subtending hyphal walls lacking discrete species-level characters; formed singly or in clusters, from the terminal tip of a sporiferous hypha or hyphae subtending an acaulosporoid spore. Acaulosporoid spores formed from a pedicel branching from the neck of a hyaline sporiferous saccule, with a spore wall consisting of three layers: a degradable and sloughing outer layer, a middle layer developing from a bilayered pedicel, and a rigid inner layer. The inner two layers of the acaulosporoid spore wall are unique in each species. An inner semi-pliable multi-layered hyaline wall forms independent of the spore wall and is indistinguishable among species.

Ambispora leptoticha (N.C. Schenck \& G.S. Sm.) R.J. Bills \& J.B. Morton comb. nov. (Figs. 2, 3a-h, 4, 5a, 6).

The species is described in Morton \& Redecker (2001). It is distinct from other species in the genus Ambispora by its rDNA characteristics (Fig. 2) and acaulosporoid spore wall morphology (Figs. 5a, 6).

Basionym: Acaulospora gerdemannii N.C. Schenck \& T.H. Nicolson, Mycologia 71:193 (1979). Acaulospora appendicula Spain, Sieverd. \& N.C. Schenck, Mycologia 76:686 (1984).

Glomus leptotichum N.C. Schenck \& G.S. Sm., Mycologia 74:82-83 (1982).

Glomus fecundisporum N.C. Schenck \& G.S. Sm., Mycologia 74:81 (1982).

Synonyms: Archaeospora leptoticha (N.C. Schenck \& G.S. Sm.) J.B. Morton \& D. Redecker, Mycologia 93:184 (2001).

Appendicispora leptoticha (N.C. Schenck \& G.S. Sm.) C. Walker, Vestberg \& Schüßler, Mycol. Res. 111:255 (2007).

Pseudoglomus leptotichum (N.C. Schenck \& G.S. Sm.) S.P. Gautam \& U.S. Patel, The Mycorrhizae, Diversity, Ecology and Applications (Delhi):5 (2007).

Ambispora leptoticha (N.C. Schenck \& G.S. Sm.) C. Walker, Mycol. Res. 112:297 (2008). Appendicispora jimgerdemannii (N.C. Schenck \& T.H. Nicolson) Spain, Oehl \& Sieverd., Mycotaxon 97:176 (2006).

Ambispora jimgerdemannii (Spain, Oehl \& Sieverd.) C. Walker, Mycol. Res. 112:298 (2008). 
Appendicispora fecundispora (N.C. Schenck \& G.S. Sm.) C. Walker, Vestberg \& Schüßler, Mycol. Res. 111:254 (2007).

Ambispora fecundispora (N.C. Schenck \& G.S. Sm.) C. Walker, Mycol. Res. 112:298 (2008).

Glomus callosum Sieverd., Angew. Botanik 62:374 (1988).

Appendicispora callosa (Sieverd.) C. Walker, Vestberg \& Schüßler, Mycol. Res. 111:254 (2007).

Ambispora callosa (Sieverd.) C. Walker Mycol. Res. 112:298 (2008).

Appendicispora appendicula (Spain, Sieverd. \& N.C. Schenck) Spain, Oehl \& Sieverd., Mycotaxon 97:170 (2006).

Paracaulospora appendicula (Spain, Sieverd. \& N.C. Schenck) S.P. Gautam \& U.S. Patel, The Mycorrhizae, Diversity, Ecology and Applications (Delhi):5 (2007).

Ambispora appendicula (Spain, Sieverd. \& N.C. Schenck) C. Walker Mycol. Res. 112:298 (2008).

Ambispora gerdemannii (S.L. Rose, B.A. Daniels \& Trappe) R.J. Bills \& J.B. Morton comb. nov. (Figs. 2, 3i-j, 5b, 7).

LSU sequence data (Fig. 2) and acaulosporoid spore wall morphological (Figs. 5b, 7) together provide strong support that Am. fennica and Am. gerdemannii are conspecific and distinct from other species in Ambispora. Both Am. fennica and Am. gerdemannii clearly are dimorphic in living cultures (Morton and Redecker 2001; Spain et al. 2006; Walker et al. 2007a).

Basionym: Glomus gerdemannii S.L. Rose, B.A. Daniels \& Trappe, Mycotaxon 8:297 (1979). Synonyms: Archaeospora gerdemannii (S.L. Rose, B.A. Daniels \& Trappe) J.B. Morton \& D. Redecker, Mycologia 93:186 (2001).

Appendicispora gerdemannii (S.L. Rose, B.A. Daniels \& Trappe) Spain, Oehl \& Sieverd., Mycotaxon 97:174 (2006).

Ambispora gerdemannii (S.L. Rose, B.A. Daniels \& Trappe) C. Walker, Vestberg \& Schüßler, Mycol. Res. 111:148 (2007).

Ambispora gerdemannii (S.L. Rose, B.A. Daniels \& Trappe) C. Walker, Mycol. Res. 112:298 (2008). 
Ambispora fennica C. Walker, Vestberg \& Schüßler, Mycol. Res. 111:148 (2007).

Appendicispora fennica (C. Walker, Vestberg \& Schüßler) C. Walker, Vestberg \& Schüßler, Mycol. Res. 111:254 (2007).

Ambispora fennica (C. Walker, Vestberg \& Schüßler) C. Walker, Mycol. Res. 112:298 (2008).

Epitype: Ambispora gerdemannii INVAM accession MT106 submitted by C. Rosier, University of Montana, Missoula, MT, March 26, 2003.

\section{Discussion}

A species is a hypothesis that sometimes requires revision as new information becomes available. The proliferation of species based on weak or selective evidence jeopardizes the information content of a classification and how that information may be utilized in comparative studies. The taxonomic history of taxa that now comprise Ambispora, the only genus in the family Ambisporaceae, exemplifies this issue. As an outcome of this study, eight species classified in Ambispora have been reduced to three species based on a congruent combination of morphological and rDNA evidence.

The redefinition of Ambispora leptoticha to include Am. fecundispora, Am. appendicula, and Am. jimgerdemannii has come full circle and represents a return to the original species hypothesis of Morton and Redecker (2001). In addition, a reinterpretation of type material and published SSU/ITS sequences of Am. callosa indicates conspecificity with Am. leptoticha. The four species resurrected from Archaeospora leptoticha by Spain et al. (2006) relied on their interpretations of morphology, which were based on three faulty premises. The first premise involved distinguishing acaulosporoid spores of putatively monomorphic Am. jimgerdemannii from dimorphic Am. appendicula based on the presumption that "cerebriform" and "crazed" phenotypes in type material were novel, stable, and discrete enough to differentiate species. Comparative analysis of these spores in 19 INVAM accessions of Am. leptoticha propagated over a 20 year period indicated that both phenotypes are extremes in a continuum of variation. These characters, therefore, are not informative either taxonomically or phylogenetically. Instead, they represent population-level variation associated with age, senescence or environmental degradation. 
Spain et al. (2006) used the same premise to separate Am. fecundispora (as Gl.fecundisporum) from Am. leptoticha (as Gl. leptotichum), whereby the surface appearance of the spore wall outer layer (of two layers) was "reticulate" (former species) or not (latter species). This layer is somewhat friable and undergoes some degradation, so a range of variation is expressed that include both phenotypes. The synonymization of each pair of species remains strictly morphological in the study here, because ex-type materials of Am. jimgerdemannii and Am. fecundispora have never been available to test hypotheses of gene phylogeny. Records indicate that no cultures were established in INVAM (as Ac. gerdemannii, G. fecundisporum) when the collection was curated by N.C. Schenck, one of the authors of both protologues.

The second premise of Spain et al. (2006) was that consistent sporulation of only one spore morphotype constituted evidence of a strict monomorphic habit. The absence of the acaulosporoid morphotypes in cultures of G. fecundisporum and G. leptotichum is not proof that this behavior does not exist because expression of dimorphism is both unpredictable and highly variable. For example, Acaulospora appendicula FL130A has produced varying frequencies of both morphotypes over 17 propagation cycles (Morton et al. 1997; Redecker et al. 2000; Morton and Redecker 2001). Another strain, Am. leptoticha VZ856, sporulates only as the acaulosporoid morph (Morton et al. 1997; Morton and Redecker 2001). In contrast, G. leptotichum FL184B has sporulated predominantly, or often exclusively, as the glomoid morph through 16 propagation cycles over 22 years (Morton et al. 1997; Morton and Redecker 2001). In their analysis, Spain et al. (2006) also failed to consider the presence of several acaulosporoid spores in the type specimen of G. leptotichum that supported dimorphism.

The taxonomy of Ambispora callosa has a confusing history. When Sieverding (1988) described Gl. callosum, dimorphism within a species had not been discovered yet. The presence of any acaulosporoid spores would likely have been interpreted as a different species. Subsequent cultures (Kojima et al. 2004; Walker et al. 2007a) appear to be exclusively monomorphic. Murakoshi et al. (1998) earlier had reported a dimorphic strain (F3b) from a single spore culture with an acaulosporoid morph similar to Ac. gerdemannii (=Am. leptoticha) and glomoid spores identified as G. leptotichum. Walker et al. (2007a) relied on the dimorphic strain F3b and two glomoid strains from Japan (OK1, MAFF520057 and V1, MAFF520058) annotated as G. leptotichum in the National Institute of Agricultural Sciences (NIAS) Genebank databases (Murakoshi et al. 1998, Saito 2001, Kojima et al. 2004) to undertake a comparative 
molecular approach. Those data were not congruent, however, with an ML SSU tree grouping the Japanese isolates with Am. leptoticha and an unrooted maximum parsimony (MP) tree of ITS sequences positioned them into separate clades. Despite these conflicting trees, the ITS data was used to define the monomorphic isolates as Am. callosa and to separate this species from Am. leptoticha. An ML phylogeny reconstructed from SSU-ITS-LSU rDNA sequences (Krüger et al. 2012) supports the SSU tree and ranks Am. callosa isolates with Am. leptoticha and Am. appendicula in a clade of equivalent topology with other Ambispora species. The inclusion of isolate F3b as an equivalent subclade, with its Am. leptoticha acaulosporoid morphotype, provides morphological evidence for synonymy.

The third premise of Spain et al. (2006) was that morphological differences between species, regardless of how small, are important for delimiting and ranking of species. However, some phenotypic differences (novelties), no matter how stable or discrete they might be, may not reflect speciation events at all but instead indicate fixation of character variants that evolved as disjunct clonal populations (Morton and Msiska 2010a, 2010b; vanKuren et al. 2013). The intercalary spore formation considered by Spain et al. (2006) to be unique to G. fecundisporum is an example of a minor character of no diagnostic merit because it occurs so rarely that it isn't even represented in type material. The same conclusion applies to phenotypes generated by artifacts of storage medium, age or parasitism.

Analysis of G. fecundisporum posed somewhat of a problem. Even though the species was described from cultures by Schenck and Smith (1982), no representative living cultures exist. Records indicate this species was never deposited as a coded accession in Florida-INVAM or in any other lab. Hence, comparative morphological evidence rested only with the type material, which was in poor condition. Phenotypic variation in glomoid spores still were not distinguishable from that in spores of other merged species when state of the material was considered.

The revision of Ambispora gerdemannii in this study corrects the interpretation of Ambispora fennica as a distinct species. Walker et al. (2007a) described Am. fennica as being "very close morphologically" to Am. gerdemannii and the comparative evidence provided in this study goes further and concludes they are indistinguishable. Dimorphism is well established, and the glomoid morph shares all of the traits of the glomoid spores of Am. leptoticha except that the size 
range is smaller. Morphology thus provides additional robust criteria to rank Am. gerdemannii within the Am. leptoticha clade.

The separation of Am. fennica from Am. gerdemannii by Walker et al. (2007a, 2007b) and Walker (2008) was based solely on SSU sequence data. This decision warrants discussion because it highlights two common problems associated with molecular data: (i) misannotations in public databases and (ii) taxon sample size. These workers relied on a single divergent SSU sequence annotated erroneously in NCBI as Am. gerdemannii. INVAM accession AU215 produced spores that matched the phenotype of Am. gerdemannii, but the representative sequences submitted to NCBI were actually those of Am. leptoticha. This pattern also was true for an AU215 ITS sequence (AJ012111). The addition of LSU sequences from two living cultures of Am. gerdemannii did not cluster with isolate AU215, providing conclusive evidence that AU215 sequences were not from spores of Am. gerdemannii.

Second, sample size greatly influences tree topology and thus ranking decisions (Pollock et al. 2002; Heath et al. 2008). rDNA sequences from Am. fennica were limited to a spore from one strain (Walker et al. 2007a; Walker 2008; Krüger et al. 2012). When additional rDNA sequences from Am. gerdemannii INVAM MT106 and Chinese strain n8_9 (JF439210) were added in an analysis by Krüger et al. (2012), these strains grouped with Am. fennica. In this study, Am. gerdemannii LSU sequences and those from one population of Am. fennica placed both taxa in a monophyletic clade equivalent in topology to the Am. leptoticha sister clade. The topology of Am. fennica as a distinct subclade likely is a reflection of limited sample size (both in number of isolates representing the species and number of samples within a population). Only $13 \mathrm{Am}$. fennica rDNA sequences published by Krüger et al (2012, Fig. 3) contained homologous LSU sequences for comparison in our study. All of these transformant clones were of a single isolate (Att200-23) and 12 were sequences from a single spore (clones MK096-1-MK096-12). Therefore, these data may not represent the scope of genetic variation in the source population, and by extension, the range of populations comprising the putative species. A similar distinct topology could be generated within Am. leptoticha when only selected strains were analyzed (result not shown). The genetic distance observed in the Am. gerdemannii clade is low, being much less than that of strains representing species clades in other genera such as Paraglomus occultum (this study), Acaulospora paulinae (Kaonongbua et al. 2010), Claroideoglomus etunicatum (van Kuren et al. 2013) and Dentiscutata heterogama (Morton and Msiska 2010b). 
Although no LSU sequence analysis was performed on Am. granatensis, enough molecular and morphological evidence exists to support the retention of Am. granatensis as a phylogenetically discrete species in Ambispora. An SSU gene tree grouped Am. granatensis in a monophyletic clade with greater sequence variation than clades that grouped sequences from $A m$. fennica and the Am. callosa/Am. appendicula clade (Palenzuela et al. 2011). At the organismal level, Am. granatensis is dimorphic in pot cultures (Palenzuela et al. 2011). Glomoid spores possess the same bilayered spore wall and subtending hyphae phenotype shared by other species in Ambispora. Acaulosporoid spores shared the same three-layered spore wall and hyaline multilayered semi-pliable inner wall, and uniqueness was expressed in divergent inner layers of the spore wall.

Phylogenetic analysis of morphology relies on shared derived characters (synapomorphies) (Hillis 1987; Davis and Nixon 1992) of discrete and stable spore phenotypes (Morton 1990; Morton and Msiska, 2010a). Results of this study indicate that novel synapomorphies separating species described to date reside in divergent phenotypes of the inner two layers of the acaulosporoid spore wall. This pattern follows a more general one in Glomeromycota, where essential species-level traits of AMF, regardless of clade, are found mostly in spore wall characters (Morton 1995; Stürmer and Morton 1997; Stürmer and Morton 1999). Unlike other glomeromycotan clades, however, Ambispora species have a capacity for dimorphism and the glomoid morphotype appears to lack any capacity for divergence as discrete and stable traits. Possibly, genes involved specifically in glomoid spore formation are historically constrained and there is little pressure to select for any emergent variants or alternatively, the phenotypic space is too narrow for expression of new and distinctive variation.

This study reveals some of the inherent difficulties in systematic interpretations of evidence at all levels. Comparative morphology relies on a broad enough sampling of specimens to distinguish variation between populations versus species so that the former are not mistaken for the latter (Morton and Msiska 2010b; Redecker et al. 2013). That was not done by Spain et al. (2006) in resurrecting four species from Ar. leptoticha. Equally important, however, are analyses that identify those morphological characters which provide unique and consistent markers of speciation. Other phenotypic differences that are the product of mutation events fixed readily because of clonal reproduction in populations must be excluded, and nowadays gene sequence analysis contribute to exposing these traits (Kaonongbua et al. 2010; Morton and Msiska 2010b). 
Similar considerations apply to comparative molecular data, either for rDNA gene repeats where concerted evolution is a critical process in homogenizing variants or where duplicate copies of protein-encoding genes exist. Linked rRNA gene polymorphisms are present in $C$. etunicatum strains that form a distinct clade, but they do not disrupt monphyly of the species (VanKuren et al. 2013). The polymorphisms appear to be maintained in disjunction nucleoli, with concerted evolution occurring within each localized rRNA gene array. Phylogeny of the beta-tubulin gene also reveals distinct subclade structure in Dentiscutata heterogama (Msiska and Morton 2009), but there is no evidence of divergent paralogs. Rather, exposure of this genetic diversity is attributed to extensive sampling of transformant clones among a range of fungal strains. As was done in this study, resolution of such conflicts resides in consideration of available evidence at all scales.

\section{Acknowledgments}

The authors thank Bill Wheeler for assistance in growing and processing AMF cultures. We also appreciate the assistance of Dr. Donna Ford-Werntz (curator of the WVU Herbarium), Dr. Richard Halse (curator Oregon State University Herbarium), Reinhard Berndt (curator of fungus collections herbaria Z+ZT Zürich, Switzerland), Janus Blaszkowski, Jim Bever and Wittaya Kaonongbua in examining herbarium and other specimens. Funding support was provided by National Science Foundation grants DBI0650735 and DEB0649341 to Joseph Morton. 


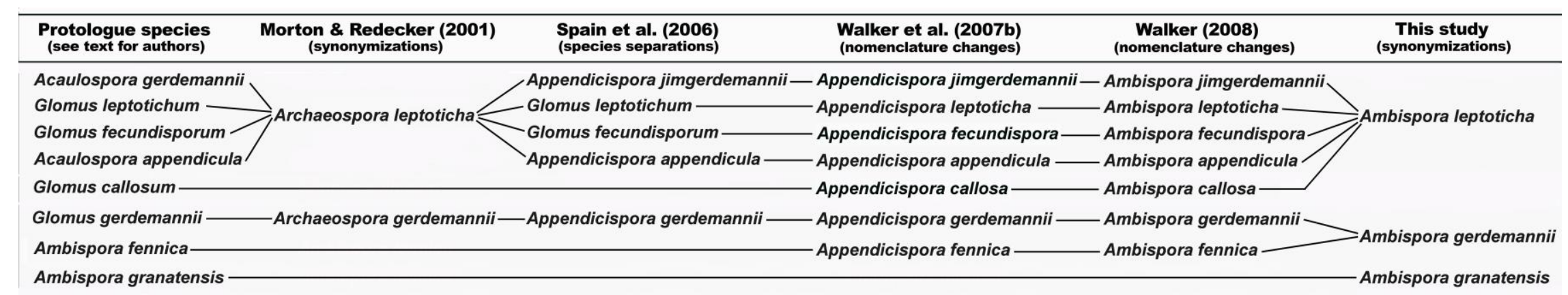

Fig. 1 Timeline summarizing major taxonomic revisions in Ambispora (Ambisporaceae). 
Fig. 2 Phylogenetic tree from partial 28S rDNA (LSU) sequences reconstructed using the Kimura-2 parameter and the maximum likelihood criterion in MEGA6. Bayesian posterior probabilities greater than 0.97 represented by thickened branches. Branch labels specify: spore morphotype ( $\mathrm{ac}=$ acaulosporoid, $\mathrm{gl}=$ glomoid) and source material (spore1, spore2, spore3) for each transformant clone, INVAM accession, and NCBI accession code. Only bootstrap values above $70 \%$ are designated. **A third party sequence submitted to GenBank and erroneously annotated as Glomus gerdemannii. 


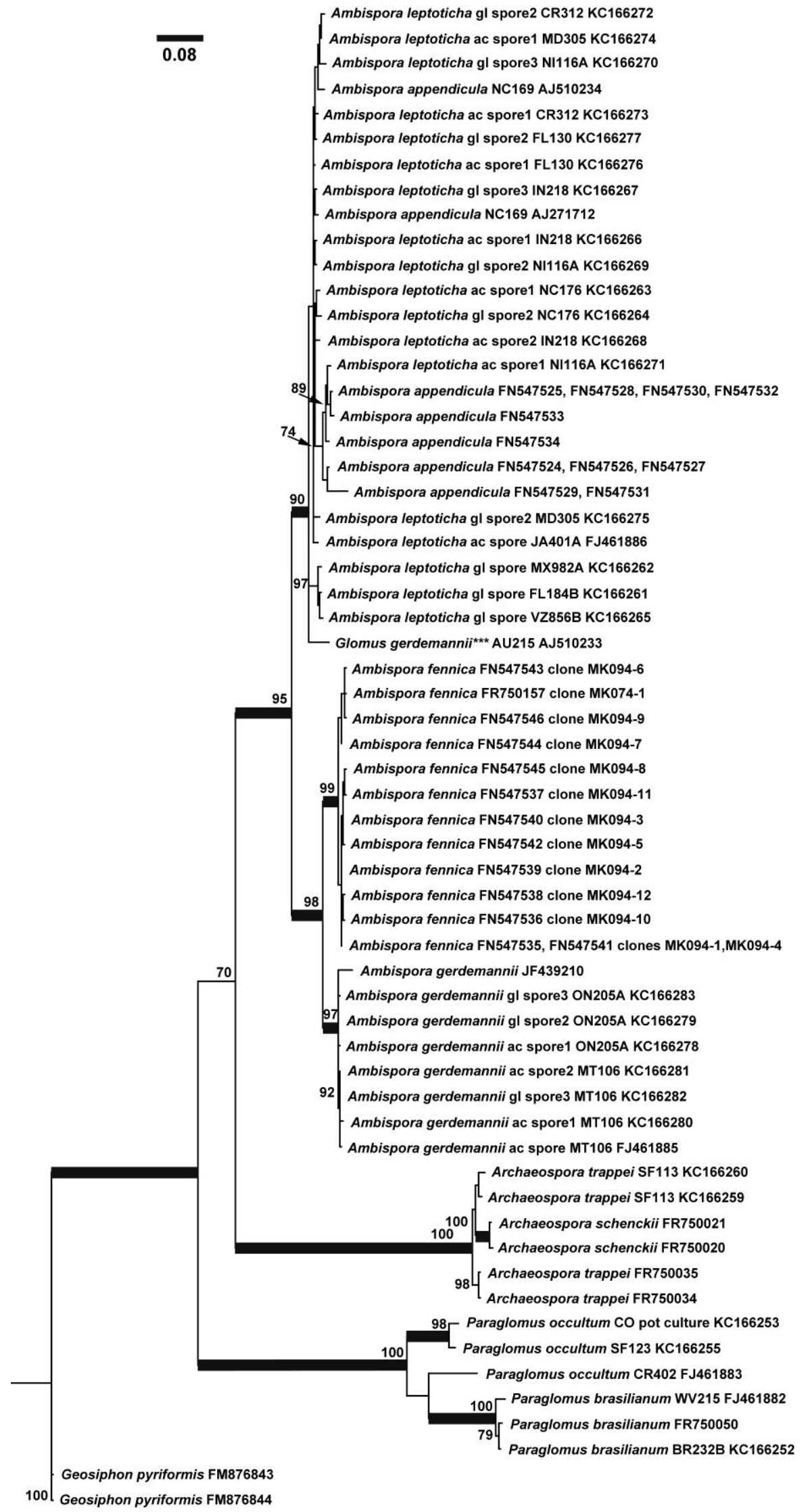


Fig. 3 Comparative morphology of glomoid spores produced by Ambispora species. All form a bilayered spore wall consisting of a somewhat friable hyaline to pale brown outer layer (L1) and a hyaline semi-pliable inner layer (L2) that is continuous with a bilayered (L1-L2) subtending hyphal wall. a Small specimen of Glomus leptotichum holotype OSC40249. b Typical specimen from G. leptotichum OSC40249. c Spore of Ambispora leptoticha from active culture FL184B. d Spore and subtending hypha of Am. leptoticha FL184B. e Spore and subtending hypha of Glomus fecundisporum OSC40250. f Spores and attached hyphae from Acaulospora gerdemannii holotype OSC37514. g Small spore from Ac. gerdemannii OSC37514. h Transition between spore and subtending hyphal wall of Acaulospora appendicula isotype FLAS F53673. i Spore of Ambispora gerdemannii MT106 with transition between bilayered spore wall and subtending hyphal wall. j Spore of Am. gerdemannii ON205. k-l Spores from Ambispora granatensis isotype $\mathrm{Z}+\mathrm{ZT}$ isotype 55-5503. Bar $=10 \mu \mathrm{m}$. 


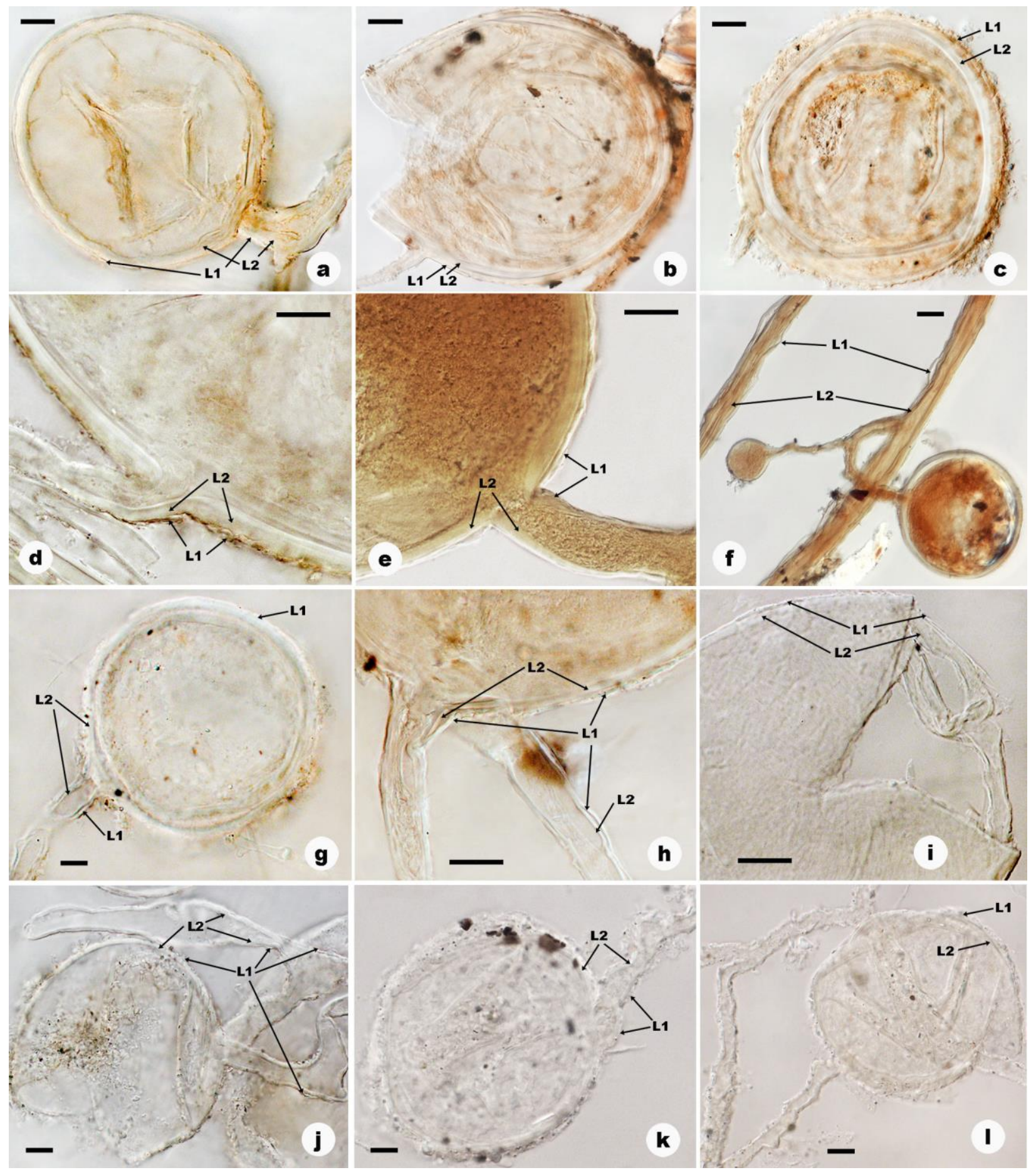



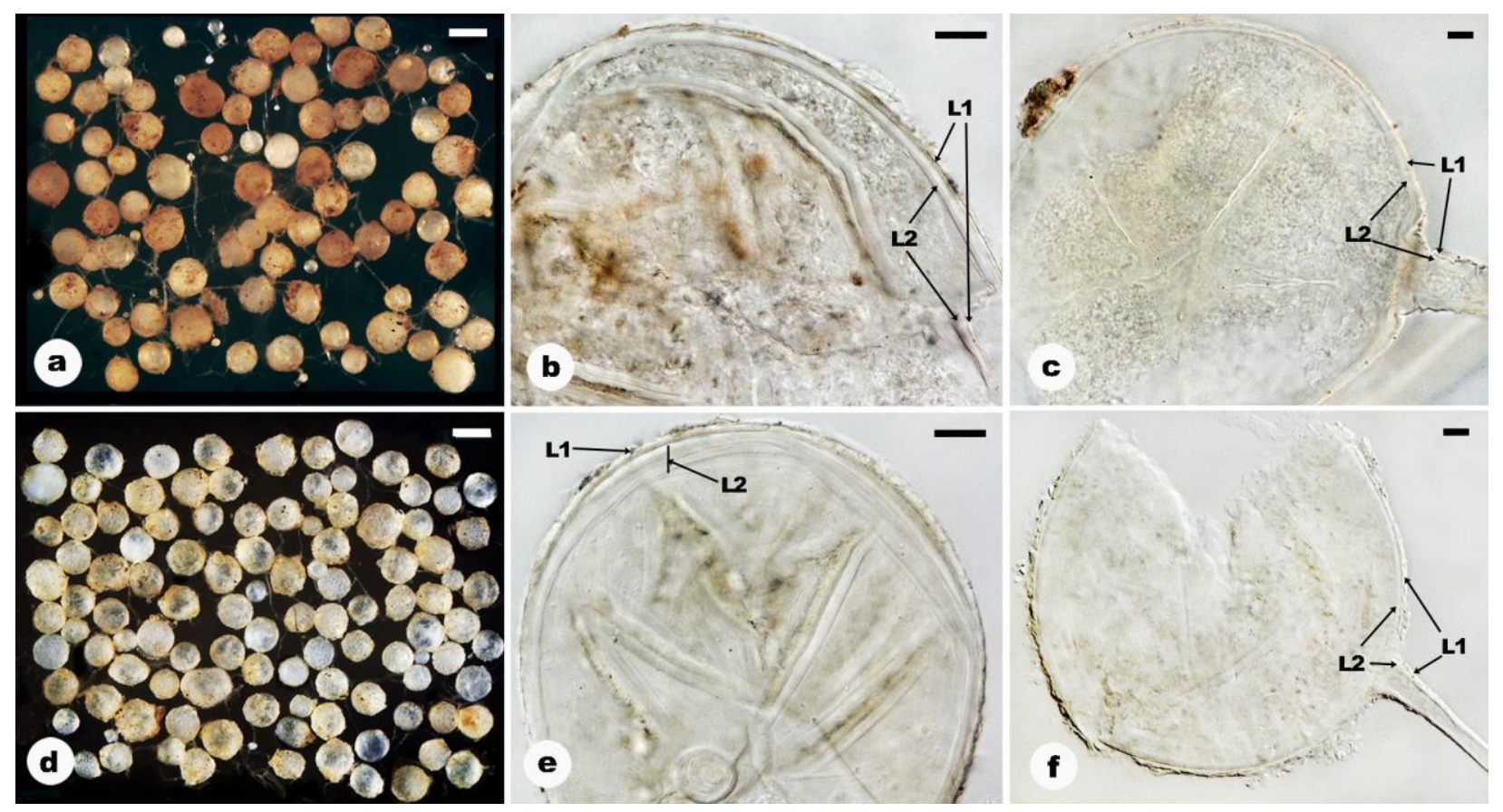

Fig. 4 Comparative morphology of whole and broken spores of Glomus callosum holotype OSC147148 (a-c) and glomoid spores of Ambispora leptoticha FL184B after nine months in refrigerated dry storage (d-f). a Whole spores in 5\% formalin (size range 60-310 $\mu \mathrm{m}$ ). b Typical spore with a friable outer layer (L1) and thicker semi-pliable inner layer (L2). c Thinner-walled spore. d Whole spores in water (size range 72-290 $\mu \mathrm{m}$ ). e Typical spore showing semi-pliable phenotype of inner spore wall layer (L2). f Thinner-walled spore. Bar for a, $d=250 \mu \mathrm{m}$, all others $=10 \mu \mathrm{m}$. 

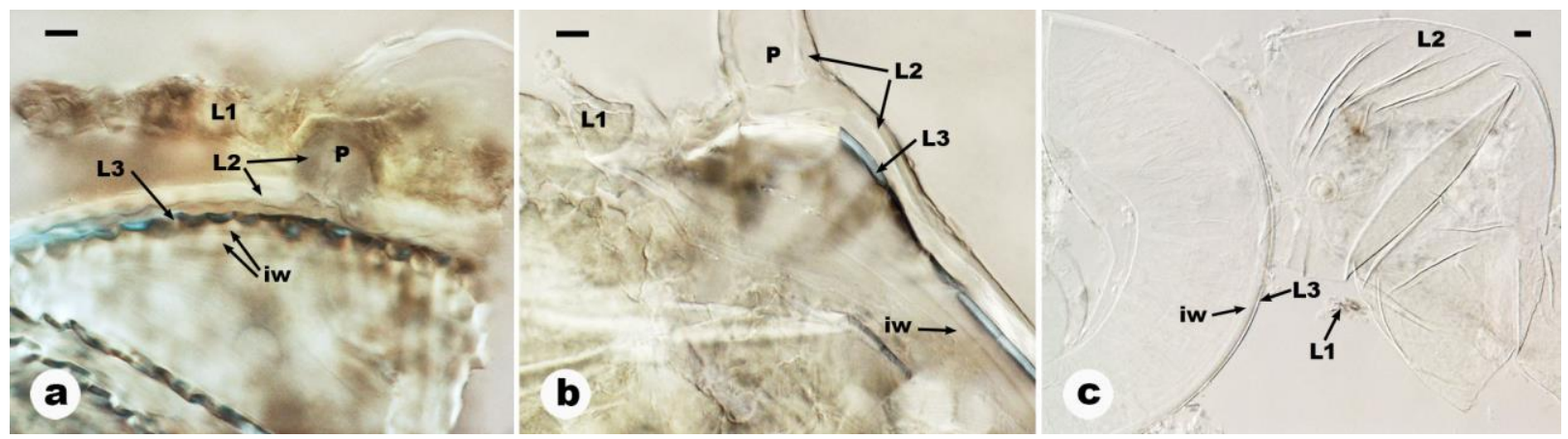

Fig. 5 Comparative morphology of acaulosporoid spores produced by known Ambispora species. All form a friable and sloughing outer spore wall layer (L1), with divergence between species expressed in phenotypes of the second (L2) and inner (L3) layers of the spore wall. The middle spore wall layer (L2) is continuous with the wall of the pedicel (P) which branches from the neck of a sporiferous saccule. a Am. leptoticha FL130A, b Am. gerdemannii ON205A c Am.

granatensis Z+ZT isotype 55-5504. A thick hyaline semi-pliable inner wall that forms separately from the spore wall (iw) varies in number and thickness of separable layers, but this phenotypic variation is shared by all three species. Bar $=5 \mu \mathrm{m}$. 

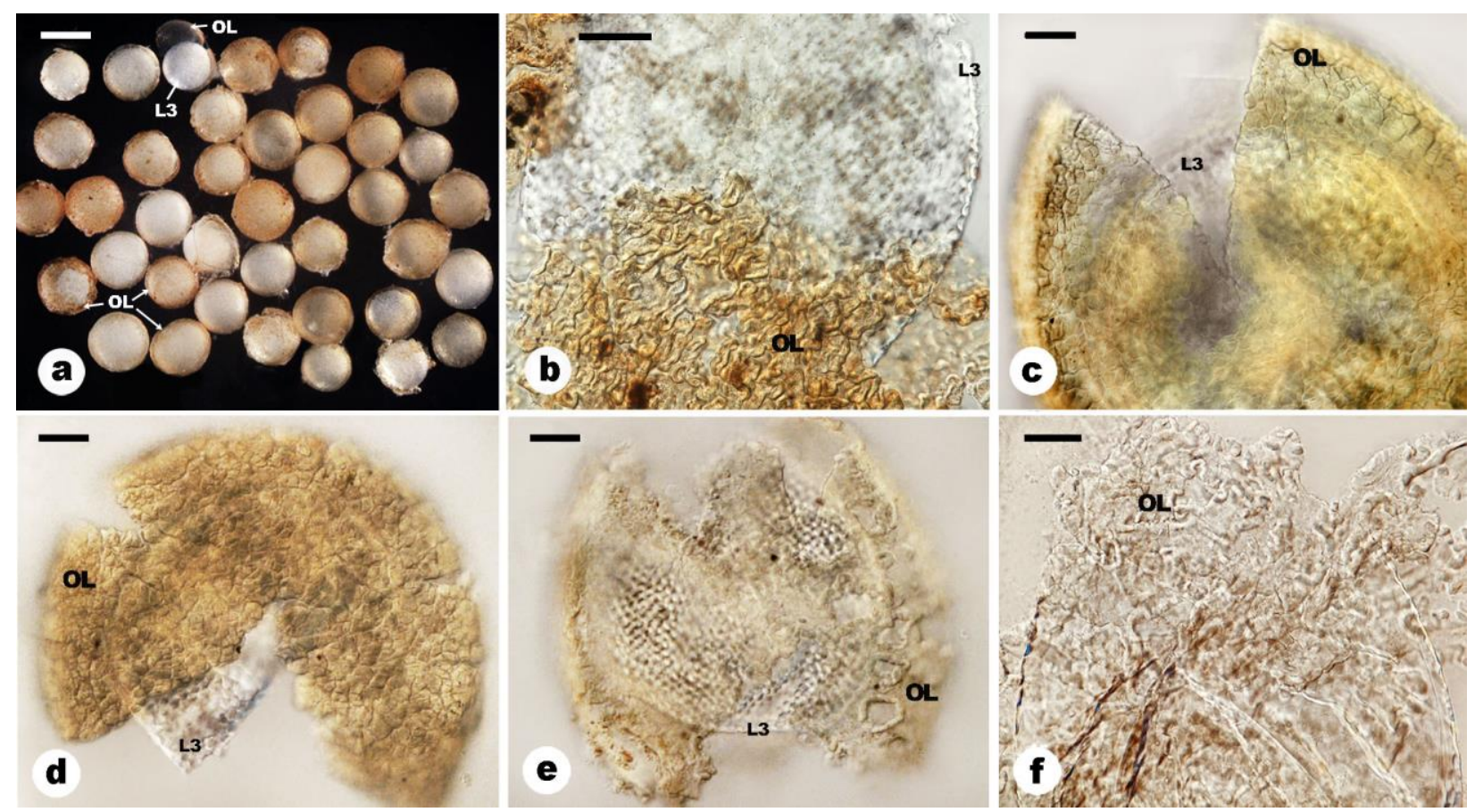

Fig. 6 Comparative morphology of the acaulosporoid spores of Ambispora species. a Spores of Am. leptoticha FL130A in water showing various stages of degradation/sloughing of the outer spore wall layer (OL) exposing the bright white ornamented inner spore wall layer (L3). b Cerebriform phenotype of spore wall outer layer from Acaulospora gerdemannii OSC37514. c Crazed phenotype of spore wall outer layer from Ac. appendicula OSC41495. d-f Spores sampled at the same time from an active culture of Am. leptoticha FL130A showing variation in phenotypes of the outer spore wall layers. $\mathbf{d}$ Crazed phenotype. e Crazed and cerebriform regions of the outer layer on the same spore. $\mathbf{f}$ Cerebriform phenotype. Bar for $\mathrm{a}=200 \mu \mathrm{m}$, for all others $=25 \mu \mathrm{m}$. 


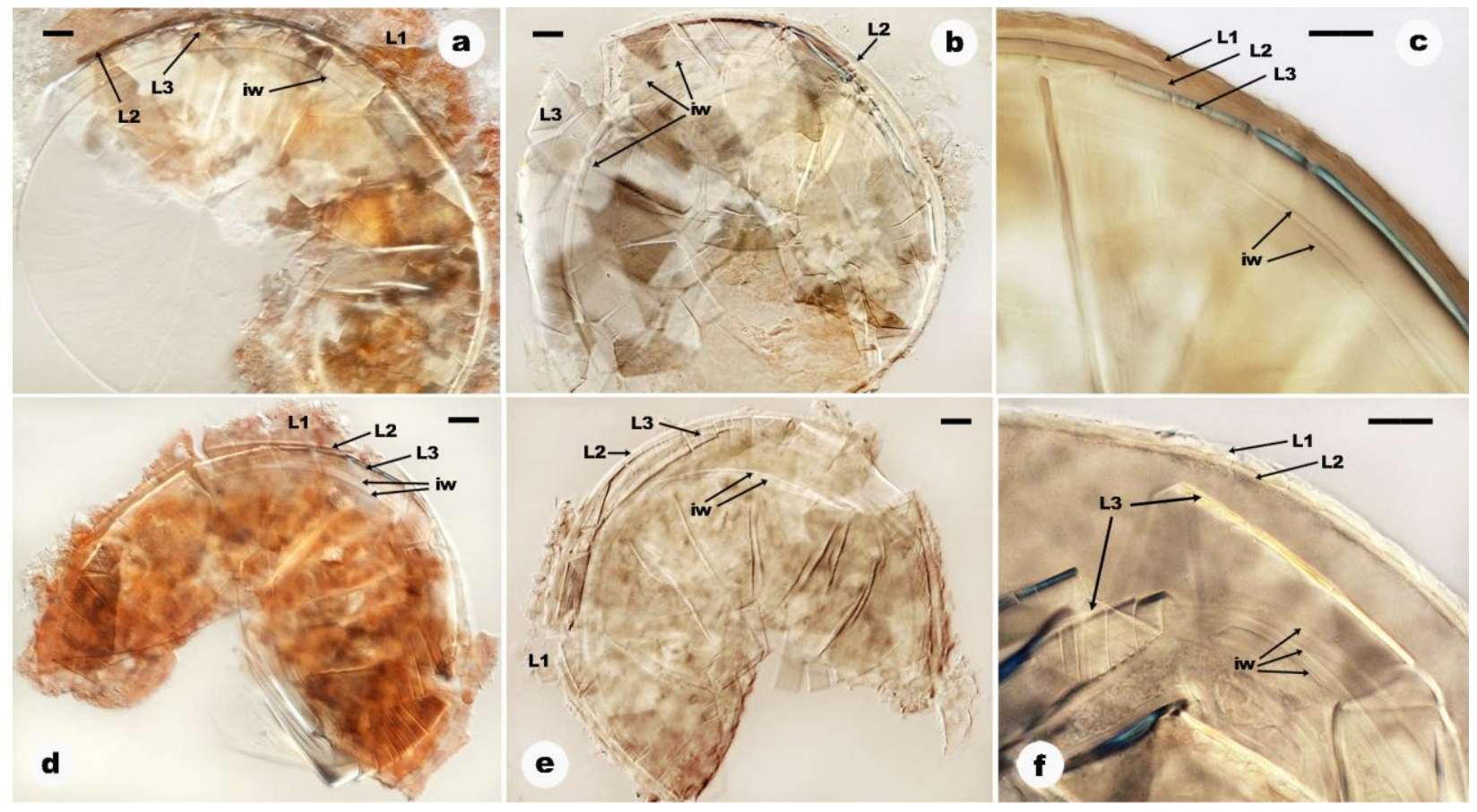

Fig. 7 Equivalence in comparative morphology of acaulosporoid spores of Ambispora fennica and Ambispora gerdemannii. Spores of Am. fennica spores mounted on slides labeled Att550-30 from J. Blaszkowski (a-c). a In Melzer's reagent, showing the dextrinoid reaction of a friable outer spore wall layer (L1), a more permanent second layer (L2), a fracturing rigid inner layer (L3), and a semi-flexible inner wall (iw). b In PVLG, with the outer layer of the spore wall (L1) mostly sloughed. c Spore with all layers of the spore wall (L1-L3) and inner wall (iw) present. Spores of Am. gerdemannii strain MT106 (d-f). d In Melzer's reagent. e In PVLG with only remnants of the outer spore wall layer (L1) present. f All layers of the spore wall (L1-L3) and inner wall (iw) present. Bar $=10 \mu \mathrm{m}$. 


\section{References}

Ames RN, Linderman RG (1976) Acaulospora trappei sp. nov. Mycotaxon 3:565-569

Davis JI, Nixon KC (1992) Populations, genetic variation, and the delimitation of phylogenetic species. Syst Biol 41:421-435

Edgar RC (2004) MUSCLE: A multiple sequence alignment method with reduced time and space complexity. BMC Bioinformatics 5:1-19

Gautam SP, Patel US (2007) Rhizoendomutualmycota (REMM): A new phylum for the farmers' friend number one. In: The Mycorrhizae: Diversity, ecology and applications. Tiwari M, Sati S.C. eds. Delhi: Daya Pub. House. p 1-13

Gerdemann JW, Trappe J (1974) The Endogonaceae in the Pacific Northwest. Mycol Mem 5:176

Heath TA, Hedtke SM, Hillis DM (2008) Taxon sampling and the accuracy of phylogenetic analyses. J Syst Evol 46:239-257

Hillis DM (1987) Molecular versus morphological approaches to systematics. Ann. Rev. Ecol. Syst. 18:23-42

Kaonongbua W, Morton JB, Bever JD (2010) Taxonomic revision transferring species in Kuklospora to Acaulospora (Glomeromycota) and a description of Acaulospora colliculosa sp. nov. from field collected spores. Mycologia 102:1497-1509

Kojima T, Sawaki H, Saito M (2004) Detection of arbuscular mycorrhizal fungi, Archaeospora leptoticha, and related species colonizing plant roots by specific PCR primer. Soil Sci Plant Nutr 50: 95-101

Koske RE, Tessier B (1983) A convenient, permanent slide mounting medium. Mycol Soc Amer Newsletter 34:59

Krüger M, Krüger C, Walker C, Stockinger H, Schüssler A (2012) Phylogenetic reference data for systematics and phylotaxonomy of arbuscular mycorrhizal fungi from phylum to species level. New Phytol 193:970-984

Morton JB (1990) Evolutionary relationships among arbuscular mycorrhizal fungi in the Endogonaceae. Mycologia 82:192-207 
Morton JB (1995) Taxonomic and phylogenetic divergence among five Scutellospora species (Glomales, Zygomycetes) based on comparative developmental sequences. Mycologia 87:127137

Morton JB, Bentivenga SP, Wheeler WW (1993) Germ plasm in the International Collection of Arbuscular and Vesicular-arbuscular Mycorrhizal Fungi (INVAM) and procedures for culture and development, documentation and storage. Mycotaxon 48:491-528

Morton JB, Bever JD, Pfleger FL (1997) Taxonomy of Acaulospora gerdemannii and Glomus leptotichum, synamorphs of an arbuscular mycorrhizal fungus in Glomales. Mycol Res 101:625631

Morton JB, Msiska Z (2010a) Phylogenies from genetic and morphological characters do not support a revision of Gigasporaceae (Glomeromycota) into four families and five genera. Mycorrhiza 19:501-513

Morton JB, Msiska Z (2010b) Ontogeny and phylogeny of Scutellospora heterogama mutant, with implications for morphological recognition of species in Glomeromycota. Fungal Biol 114:410-420

Morton JB, Redecker D (2001) Two new families of Glomales, Archaeosporaceae and Paraglomeraceae, with two new genera Archaeospora and Paraglomus, based on concordant molecular and morphological characters. Mycologia 93:181-195

Msiska Z, Morton JB (2009) Phylogenetic analysis of the Glomeromycota by a partial $\beta$-tubulin gene. Mycorrhiza 19:247-254

Murakoshi T, Tojo M, Walker C, Saito M (1998) Arbuscular mycorrhizal fungi on adjacent semi-natural grasslands with different vegetation in Japan. Mycoscience 39: 455-462

Nei M, Kumar S (2000) Molecular Evolution and Phylogenetics. New York, Oxford University Press.

Nicolson TH, Schenck NC (1979) Endogonaceous mycorrhizal endophytes in Florida. Mycologia 71:178-198

Oehl F, Sieverding E, Palenzuela J, Ineichen K, da Silva GA (2011) Advances in Glomeromycota taxonomy and classification. IMA Fungus 2:191-199 
Oehl F, Castillo C, Schneider D, Säle, V, Sieverding E (2012) Ambispora reticulata, a new species in the Glomeromycota from mountainous areas in Switzerland and Chile. J Appl Bot Food Qual 85:129-133

Palenzuela J, Barea J, Ferrol N, Oehl F. 2011. Ambispora granatensis, a new arbuscular mycorrhizal fungus, associated with Asparagus officinalis in Andalucia (Spain). Mycologia 103:333-340.

Pollock DD, Zwickl DJ, McGuire JA, Hillis DM (2002) Increased taxon sampling is advantageous for phylogenetic inference. Syst Biol 51:664-671

Redecker D, Morton JB, Bruns TD (2000) Ancestral lineages of arbuscular mycorrhizal fungi (Glomales). Mol Phylogenet Evol 14:276-284

Redecker D, Raab P (2006) Phylogeny of the Glomeromycota (arbuscular mycorrhizal fungi): Recent developments and new gene markers. Mycologia 98:885-895

Redecker D, Schüßler A, Stockinger H, Stürmer SL, Morton JB, Walker C (2013) An evidencebased consensus for the classification of arbuscular mycorrhizal fungi (Glomeromycota). Mycorrhiza 23:515-531

Ronquist F, Teslenko M, Van Der Mark P, Ayres DL, Darling A, Höhna S, Larget B, Liu L, Suchard MA, Huelsenbeck JP (2012) MrBayes 3.2: efficient Bayesian phylogenetic inference and model choice across a large model space. Syst Biol 61:539-542

Rose S, Daniels BA, Trappe JM (1979) Glomus gerdemannii sp. nov. Mycotaxon 8:297-301

Saito M (2001) Maintenance of living culture collection of arbuscular mycorrhizal fungi. MAFF Microorgansim Genetic Resources Manual No.9. National Institute of Agrobiological Resources, Ministry of Agriculture, Forestry and Fisheries, Japan. doi:

https://www.gene.affrc.go.jp/pdf/manual/micro-09.pdf

Sawaki H, Sugawara K, Saito M (1998) Phylogenetic position of an arbuscular mycorrhizal fungus, Acaulospora gerdemannii, and its synamorph Glomus leptotichum, based on 18S rRNA gene sequence. Mycoscience 39:477-480

Schenck NC, Smith GS (1982) Additional new and unreported species of mycorrhizal fungi (Endogonaceae) from Florida. Mycologia 74:77-92 
Schenck NC, Spain JL, Sieverding E, Howeler RH (1984) Several new and unreported vesiculararbuscular mycorrhizal fungi (Endogonaceae) from Colombia. Mycologia 76:685-699

Schüßler A (2002) Molecular phylogeny, taxonomy, and evolution of Geosiphon pyriformis and arbuscular mycorrhizal fungi. Plant Soil 244:75-83

Schüßler A, Schwarzott D, Walker C (2001) A new fungal phylum, the Glomeromycota: evolution and phylogeny. Mycol Res 105:1413-1421

Sieverding E (1988) Two new species of vesicular arbuscular mycorrhizal fungi in the Endogonaceae from tropical highlands of Africa. Angew Botanik 62:373-380

Sieverding E, Toro S (1987) Entrophospora schenckii, a new species in the Endogonaceae from Colombia. Mycotaxon 28:209-295

Spain JL, Sieverding E, Oehl F (2006) Appendicispora: a new genus in the arbuscular mycorrhiza-forming Glomeromycetes, with a discussion of the genus Archaeospora. Mycotaxon 97:163-182

Stockinger H, Krüger M, Schüßler A (2010) DNA barcoding of arbuscular mycorrhizal fungi. New Phytol 187:461-474

Stürmer SL, Morton JB (1997) Developmental patterns defining morphological characters in spores of species in Glomus (Glomales, Zygomycetes). Mycologia 89:72-81

Stürmer SL, Morton JB (1999) Scutellospora rubra, a new arbuscular mycorrhizal species from Brazil. Mycol Res 103:949-954

Tamura K, Stecher G, Peterson D, Filipski A, Kumar S (2013) MEGA6:Molecular evolutionary genetics analyses version 6.0. Mol. Biol. Evol. 30: 2725-2729

Trouvelet S, van Tuinen D, Hijri M, Gianinazzi-Pearson V (1999) Visualization of ribosomal DNA loci in spore interphasic nuclei of glomalean fungi by fluorescence in situ hybridization. Mycorrhiza 8:203-206

vanKuren NW, den Bakker HC, Morton JB, Pawlowska TE (2013) Ribosomal RNA gene diversity, effective population size, and evolutionary longevity in asexual Glomeromycota. Evolution 67:207-224 
van Tuinen D, Jacquot E, Zhao B, Gollotte A, Gianinazzi-Pearson V (1998) Characterization of root colonization profiles by a microcosm community of arbuscular mycorrhizal fungi using $25 \mathrm{~S}$ rDNA-targeted nested PCR. Mol Ecol 7:879-887

Walker C, Vestberg M, Demircik F, Stockinger H, Saito M, Sawaki H, Nishmura I, Schüßler A (2007a) Molecular phylogeny and new taxa in the Archaeosporales (Glomeromycota): Ambispora fennica gen. sp. nov., Ambisporaceae fam. nov., and emendation of Archaeospora and Archaeosporaceae. Mycol Res 111:137-153

Walker C, Vestberg M, Schüßler A (2007b) Nomenclatural clarification in Glomeromycota. Mycol Res 111:253-256

Walker C (2008) Ambispora and Ambisporaceae resurrected. Mycol Res 112:297-298

White TJ, Bruns T, Lee S, Taylor J (1990) Amplification and direct sequencing of fungal ribosomal RNA genes for phylogenetics. In: Innis MA, Gelfand DH, Sninsky JJ, White TJ, (eds.) PCR protocols: A guide to methods and applications. Academic Press, San Diego, pp 315-322 


\section{CHAPTER 3}

\section{MORPHOLOGY AND AN LSU PHYLOGENY REVEAL ARCHAEOSPORA TRAPPEI AND AR. SCHENCII ARE SYNONYMOUS AND MODE OF SPORE FORMATION RESOLVES ONLY STABLE POPULATION-LEVEL VARIATION²}

\section{Introduction}

Classification of arbuscular mycorrhizal fungi (AMF) into species requires a broad sampling of specimens for comparative morphology and molecular analysis in order distinguish population-level from species-level variation (Morton \& Msiska 2010b; Bills \& Morton 2015).

The asexual mode of reproduction in AMF can complicate ranking decisions because it may lead to fixation of heritable mutations at any level (Kaonongbua et al. 2010; Msiska \& Morton 2010b; Bills \& Morton 2015). Archaeospora trappei and Ar. schenckii are two species in the family Archaeosporaceae (Archaeosporales), which exemplify some of the challenges in defining species boundaries (Schüßler \& Walker 2010; Krüger et al. 2012).

Both Ar. trappei and Ar. schenckii produce tiny hyaline spores that originate from the hypha of a precursor sporiferous saccule and they share identity in spore morphology (Morton \& Redecker 2001; Sieverding \& Oehl 2006; Schüßler \& Walker 2010; Oehl et al. 2011). The two species differ in only one trait, and that is position of the spore as it originates from the hypha of a precursor sporiferous saccule. Spores of Ar. trappei form laterally from the saccule hypha. This similarity in spore ontogeny shared by species in Acaulospora led to classification of this species first as Acaulospora trappei (Ames \& Linderman 1976). Spores of Ar. schenckii, in contrast, form within the saccule hypha (Sieverding et al. 1987). Similarity in mode of spore formation shared by species was used for higher taxonomic rankings. Between then and now, phylogenies reconstructed from rRNA genes led to several revisions in classification within the AMF. Morton and Redecker (2001) identified Ac. trappei as one of several deeply rooted species of AM fungi, and reclassified the species as a member of the new genus Archaeospora in a new family Archaeosporaceae. Sieverding \& Oehl (2006) recognized E. schenckii and Ar. trappei as being closely related based on identical spore subcellular structure and similar weakly staining mycorrhizae roots. However, these workers still gave mode of spore formation primacy and

\footnotetext{
${ }^{2}$ Formatted as manuscript for submission to journal Fungal Biology
} 
transferred E. schenckii to the monospecific genus Intraspora in Archaeosporaceae. Evidence began to accumulate indicating the entrophosporoid mode was a widely convergent trait in Glomeromycota. In Acaulosporaceae, species develop either acaulosporoid or entrophosporoid spores (Kaonongbua et al. 2010; Palenzuela et al. 2010; Oehl et al. 2011; Krüger et al. 2012). In Diversisporaceae, the glomoid mode of spore development dominates, but taxa that develop entrophosporoid spores also are present (Palenzuela et al. 2010; Oehl et al. 2011). Recognition of this pattern led to synonymization of Intraspora and Archaeospora as congeneric (Schüßler \& Walker 2010), thus grouping Ar. schenckii and Ar. trappei as sister taxa. Sequences of a $1.5 \mathrm{~kb}$ rDNA fragment from transformants of single Ar. trappei and Ar. schenckii strains (Krüger et al. 2012) further supported this move.

The goal of this study was to determine whether the respective acaulosporoid and entrophosporoid modes of spore formation by the otherwise morphologically identical $A r$. trappei and Ar. schenckii resolved species-level differences or indicated the rare occurrence of dimorphism among conspecific populations. Morphology was reexamined to assess the degree of variability amongst a broad range of strains and a 700-725 bp sequence near the $5^{\prime}$ end of the LSU gene was used to assess genetic relatedness.

\section{Materials and methods}

\section{Fungal materials}

Archaeospora schenckii was represented by extype OSC46030 of E. schenckii, a living culture of INVAM accession CL401, and four cultures started from single spores (CL401-ss1-4). Acaulospora trappei was represented by holotype OSC35917 and 10 strains from seven countries (see Fig 1). Phylogenetic analysis also included living cultures of two species in Paraglomus, another deeply rooted clade (Fig 1).

All fungal strains were propagated on Sorghum sudanense (Staph.) according to protocols described by Morton et al. (1993). Voucher specimens consisted of spores permanently mounted on glass slides in polyvinyl-lactic acid-glycerol (PVLG, Koske \& Tessier 1983) and PVLG mixed with Melzer's reagent (1:1 v/v). Specimens were examined with a Nikon Eclipse E600 microscope (Nikon Instruments, Melville, New York) equipped with differential interference contrast (DIC) optics and photographed with a Nikon DS-Ri1 digital camera. Images were 
captured with Nikon NIS-Elements imaging software (ver. 2.34). Spore morphological characters use the terminology of Morton \& Redecker (2001).

\section{DNA extraction, amplification and sequencing of rDNA}

Identity of all Ar. schenckii and Ar. trappei spores used for DNA extraction was verified by presence of an attached sporiferous saccule and then handpicked with a single-use micropipette. Only single sonicated spores of Ar. schenckii and Ar. trappei were selected for each amplification. A spore was crushed in a $0.2 \mathrm{~mL}$ microcentrifuge tube containing $14 \mu \mathrm{L} \mathrm{10X} \mathrm{Taq}$ polymerase buffer (New England Biolabs, Ipswich, MA) with a UV sterilized micropestle (Kontes Pellet Pestle). Tube contents were transferred immediately to $94{ }^{\circ} \mathrm{C}$ water bath for 4 min, snap chilled and stored on ice until amplification.

Two rounds of $50 \mu \mathrm{l}$ PCR amplification were performed to generate enough product of a 700-750bp LSU fragment for cloning (vanTuinen et al. 1998). Primer pair ITS1 and NDL22 were used for the first round of amplification, followed by a nested amplification using primers LR1 and FLR2 (White et al. 1990; van Tuinen et al. 1998; Trouvelet et al. 1999). The first PCR amplification contained $4 \mu 1$ spore DNA, $3 \mu 1$ 10x PCR buffer (New England BioLabs, Ipswich, MA), $0.2 \mathrm{mM}$ of each dNTP, $1.5 \mathrm{mM} \mathrm{MgCl}_{2}, 5 \mathrm{pM}$ of each primer, and $0.1 \mu 1$ of Taq DNA polymerase (New England BioLabs, Ipswich, MA). The second round of PCR was similar but used $1 \mu \mathrm{l}$ of first amplification product as template in $7 \mu 1$ 10x PCR buffer. Cycling parameters for both PCR reactions entailed initial denaturation at $94{ }^{\circ} \mathrm{C}$ for $4 \mathrm{~min}, 30$ cycles at $94{ }^{\circ} \mathrm{C}$ for 30 $\mathrm{s}$, annealing at $58{ }^{\circ} \mathrm{C}$ for $1 \mathrm{~min}$, extension at $72{ }^{\circ} \mathrm{C}$ for $1 \mathrm{~min}$, and a final extension at $72{ }^{\circ} \mathrm{C}$ for $10 \mathrm{~min}$. Amplicons $(8 \mu \mathrm{l})$ were stained with ethidium bromide and electrophoresed on a $1.5 \%$ agarose gel and visualized by UV illumination, purified with QIAquick PCR Purification kit (Qiagen USA, Valencia, CA), cloned with pCR®4-TOPO plasmid vector and transformed using One Shot ${ }^{\circledR}$ TOP10 chemically competent cells (Invitrogen, Carlsbad, CA). Positive transformants were verified with colony PCR using LR1/FLR2 primers. Colony PCR reactions were performed in $12.5 \mu \mathrm{L}$ containing $1 / 4$ volume of PCR reagents, transformants sampled by pipette tip in $5.93 \mu \mathrm{L}$ nuclease free water, and $0.1 \mu \mathrm{L}$ of Taq DNA polymerase. Cycling parameters were identical to regular PCR. Plasmid DNA containing the insert was purified using QIAprep Miniprep kit and sequenced at Davis Sequencing (Davis, CA, USA) using M13 
primers. LSU sequences were deposited in NCBI KT250767-KT250842. The sequence alignment is available on the INVAM website (http://invam.wvu.edu/).

\section{Phylogenetic analyses}

Sequence chromatographs were inspected in Biological Sequence Alignment Editor (BioEdit, www.mbio.ncsu.edu/BioEdit/bioedit.html) and subjected to a search on the NCBI nucleotide Basic Local Alignment Search Tool (BLASTn) to verify homology with other glomeromycotan fungal sequences. Nucleotide sequences were aligned using MUSCLE (Edgar 2004), inspected and edited in MEGA6 (Tamura et al. 2013). Phylogenetic trees were reconstructed using both Bayesian and maximum likelihood (ML) methods. MEGA6 was used to determine the best evolutionary model and nucleotide substitution pattern. The Kimura 2 parameter model plus gamma $(\mathrm{K} 2 \mathrm{P}+\mathrm{G})$ had the lowest Bayesian inference criteria (BIC) score and was selected for analyses (Nei \& Kumar 2000) with four discrete gamma categories. Bayesian phylogeny reconstruction was carried out in MrBayes 3.2.2 (Ronquist et al. 2012; http://mrbayes.net). Settings included the 4 by 4 general-type DNA model, general time reversible (GTR) substitution model converted to K2P by fixing stationary state frequencies to equal (http://mrbayes.sourceforge.net/wiki), and ploidy set to haploid. The analysis included two runs of 10,000,000 generations with a burn-in of 2,500,000 generations. MrBayes tree with posterior probabilities was visualized in FigTree v1.3.1

(http://tree.bio.ed.ac.uk/software/figtrees). The ML method was implemented in MEGA6 with 1000 replications to assess bootstrap support (Tamura et al. 2013).

\section{Results}

\section{Phylogenetic analyses}

LSU sequences grouped Ar. trappei and Ar. schenckii strains in a highly supported monophyletic clade, thus providing molecular evidence of conspecificity (Fig 1). MrBayes and ML phylogenetic trees were identical in topology. Sequences of some Ar. trappei strains segregated into a highly supported subclade, but others grouped closely with isolates of Ar. schenckii. The divergent subclades, designated here as Ar. trappei subclade-1 and Ar. trappei subclade-2, did not compromise monophyly of Ar. trappei, based on equivalence in tree topology. Although clones and NCBI accessions of Ar. schenckii clustered within Ar. trappei subclade-2 with high 
support, short branch lengths signified very low nucleotide divergence. In fact, sequences from some Ar. trappei and Ar. schenckii spores were identical. Some strains of Ar. trappei (FL327C, NC104B, SF119B) yielded identical sequences, as did Ar. trappei accessions from NCBI (FR750036-FR750038, clones of pCK082). Similarly, some sequences within and between spores of Ar. schenckii, were identical. A similar pattern of sequence variation was measured in Paraglomus occultum, a member of another deeply rooted clade.

Analysis of evolutionary divergence between groups of sequences in this study for both Ar. trappei subclades (without Ar. schenckii sequences), Ar. schenckii, Ambispora gerdemannii, Am. leptoticha, Paraglomus brasilianum and P. occultum were estimated in MEGA 6. The average distance was calculated from the arithmetic mean of all pairwise distances between groups in the inter-group comparisons (Table 1). Divergence between Ar. trappei subclade-1 and Ar. trappei subclade-2 was 0.168 (SE 0.016) while that between Ar. trappei subclade-2 and Ar. schenckii was 0.030 (SE 0.004). Divergence between the two Ar. trappei subclades was greater than divergence in Ambispora leptoticha and Am. gerdemannii (0.069 SE 0.010) and Paraglomus brasilianum and P. occultum (0.111 SE 0.012).

The sequence alignment was visually inspected for patterns of mutation and insertion/deletions and possible sources of divergence between Ar. trappei subclades. There were 110 point mutations (64 transitions, 38 transversions and 8 indels) distinguishing Ar. trappei subclade-1 from Ar. trappei subclade-2 (without Ar. schenckii sequences). Archeaospora schenckii and Ar. trappei subclade-2 sequences contained the same nucleotide substitutions that distinguished Ar. trappei subclade-2 from Ar. trappei subclade-1. Within Ar. trappei subclade-2, sequence variation between Ar. trappei and Ar. schenckii consisted of only eleven discrete mutations (six transitions, four transversions and one indel).

\section{Morphological analysis of specimens}

Spore morphology of both type specimens and living reference cultures of Ar. trappei and Ar. schenckii were indistinguishable except for mode of spore formation (Fig 2A-I). Only rarely were both spore phenotypes found in the same culture of CL401, but detection was possible only from immature spores with attached saccules mounted on glass slides (Fig 2B, F). Spore size also overlapped among strains (Table 2). 
The spore wall consisted of two discrete layers and an inner wall. The outer layer $(L 1)$ originated from the wall of the sporiferous saccule's subtending hypha and was hyaline, thin (1.0-1.2 $\mu \mathrm{m}$ ), and somewhat flexible with applied pressure under a slide coverslip (Fig 2C-D, G$\mathrm{H})$. The inner layer $(L 2)$ also was thin $(0.5-1.0 \mu \mathrm{m})$, hyaline and semi-flexible. The separate hyaline inner wall $(i w)$ was thicker $(1.3-2.5 \mu \mathrm{m})$ but also exhibited some flexibility. The spore wall outer layer, together with the sporiferous saccule, degraded with age and then become detached, leaving behind either one (acaulosporoid) or two (entrophosporoid) scars on the spore wall. The inner wall $(i w)$ developed independently to form an endospore that enveloped spore contents (Fig 2C-E, H-I).

\section{Revised classification}

The absence of LSU sequence divergence (Fig 1) and identity in spore subcellular structure (Fig 2), collectively provide evidence indicating that Ar. trappei and Ar. schenckii are conspecific and that the entrophosporoid mode of spore development was an isolated mutational event that, once fixed, led to stable divergent populations. Therefore Ar. schenckii is combined with Ar. trappei into one species, with different populations of Ar. trappei producing either acaulosporoid spores or entrophosporoid spores or more rarely, both morphotypes.

Archaeospora trappei (J.B. Morton \& Redecker) R.J. Bills \& J.B. Morton, combo. nov. (Figs 1 and 2, Table 2).

Basionym: Acaulospora trappei R.N. Ames \& Linderman, Mycotaxon 3: 566. 1976. Synonyms: Entrophospora schenckii Sieverd. \& S. Toro, Mycotaxon 28: 210 (1987) Intraspora schenckii (Sieverd. \& Toro) Oehl \& Sieverd., J. Appl. Bot. Food Quality (Angew. Botan.) 80:77 (2006)

Archaeospora schenckii (Sieverd. \& S.Toro) C. Walker \& A. Schüßler, The Glomeromycota: a species list with new families and new genera. The Royal Botanic Garden Edinburgh, The Royal Botanic Garden Kew, Botanishce Staatssammlung Munich, and Oregon State University. Printed copy available under ISBN-13: 978-1466388048, ISBN-10: 1466388048 (2010).

Arbuscular mycorrhizal forming fungi producing either acaulosporoid or entrophosporoid spores formed singly or occasionally in pairs from the hypha of a sporiferous saccule. Acaulosporoid 
spores form laterally and entrophosporoid spores form within the hypha. Spore subcellular structure, regardless of mode of formation, consists of a two-layered spore wall and a separate semi-flexible inner wall, all of which are hyaline (Morton \& Redecker 2001). More variation exists in LSU sequences among acaulosporoid strains than between acaulosporoid and entrophosporoid strains.

\section{Discussion}

Testing species hypotheses requires appropriate sampling, both within and among geographically distant populations in order to identify the range of variation within a species (morphological and molecular) and then establishing the appropriate grouping and ranking criteria for both data sets (Redecker et al. 2013). The combined morphological and molecular analyses in this study indicate Ar. trappei and Ar. schenckii are not sufficiently distinct for species separation to be supported. The acaulosporoid and entrophosporoid modes of spore formation from a precursor sporiferous saccule are all convergent traits and divergent LSU gene polymorphisms are stable population-level variants that evolved in some Glomeromycota including Ar. trappei.

Morphological traits associated with formation of a sporagenous saccule, mode of spore formation, and spores that develop from them have three levels of resolution for classifying AMF. First, the sporogenous saccule that forms prior to spore development has few distinct character states, varying mostly in size. However, this saccule variation usually correlates with spore size and is not unique above the species level (Morton 1988). Therefore, it has no phylogenetic value. The independent evolution of a sporogenous saccule in five families (Acaulosporaceae, Ambisporaceae, Archaeosporaceae, Diversisporaceae, Glomeraceae) clearly establishes that it is a convergent character (Morton \& Benny 1990; Morton \& Redecker 2001; Walker et al. 2007; Palenzuela et al. 2010; Oehl et al. 2011; Bills \& Morton 2015). Beyond the repeated evolution of this structure in genetically distant clades, little is known about the causal basis for emergence of this trait or its functional attributes beyond a precursor structure for spore development.

Second, the acaulosporoid and entrophosporoid modes of spore formation are also convergent traits within the Glomeromycota, but can resolve taxa within clades. The acaulosporoid mode evolved in two divergent families Acaulosporaceae and Archaeosporaceae (Gerdemannii \& Trappe 1974Morton et al. 1997; Redecker et al. 2000; Morton \& Redecker 
2001; Walker et al. 2007; Kaonongbua et al. 2010; Walker \& Schüßler 2010; Bills \& Morton 2015). In Acaulosporaceae, the acaulosporoid mode of spore formation is a heritable trait shared among species in Acaulospora and is informative as a grouping criterion. The acaulosporoid mode of spore formation as a grouping criterion in Archaeosporaceae remains enigmatic, as only one species is currently described in monogeneric Archaeospora.

Mode of spore formation in Ambispora is unique, as the clade contains three dimorphic species that form a bilayered glomoid phenotype and a more complex glomoid spore that forms from a bilayered "pedicel" that branches from hypha subtending a precursor saccule (Bills \& Morton 2015).

The entrophosporoid mode of spore formation also originated multiple times in four different glomeromycotan families, but as it failed to define lineages above species level is only suitable for grouping populations. rDNA phylogenies have placed the phenotype in Acaulosporaceae (Acaulospora colliculosa, Acaulospora columbiana, Acaulospora kentinensis) Archaeosporaceae (Ar. trappei), Claroideoglomeraceae (Entrophospora infrequens) and Diversisporaceae (Entrophospora baltica, Entrophospora nevadensis) (Sieverding \& Oehl 2006; Kaonongbua et al. 2010; Walker \& Schüßler 2010; Oehl et al. 2011; Redecker et al. 2013). While the entrophosporoid phenotype discriminates at the species level Ac. colombiana from in lineages Ac. denticulata, Ac. mellea, and Ac. morrowiae (Msiska \& Morton 2009a; Kaonongbua et al. 2010; Krüger et al. 2012; Krüger et al. 2013). In Ar. trappei, acaulosporoid and entrophosporoid modes of spore formation are rarely detected together in some isolates, rendering each phenotype unsuitable to reliably group populations that diverge into two discrete subclades using the LSU marker gene.

The independent evolution of the entrophosporoid mode of spore formation was extremely rare. Within the monogeneric Acaulosporaceae, the entrophosporoid phenotype arose in only three of the 37 described species in the clade (Kaonongbua et al. 2010). Regardless of spore position, later stages of spore ontogeny were similar in all taxa within the clade. Additional evidence from Acaulospora rDNA and B-tubulin gene phylogenies did not group the three entrophosporoid taxon, Ac. colombiana, Ac. kentinensis, and Ac. colliculosa, together into a single monophyletic clade but indicated that each shared more recent ancestry with a different acaulosporoid sister taxa (Morton \& Msiska 2009a, Kaonongbua et al. 2010; Krüger et al. 20112 Krüger et al. 2013). 
Historically, detection of Ar. schenckii also was rare compared to globally distributed strains of Ar. trappei. Sieverding \& Oehl (2006) reported the detection of Ar. schenckii in only five countries. Other diversity studies that identified Ar. trappei or Ar. schenckii reported the former 67 times and the latter only nine times (Stürmer \& Morton in prep.). Both taxa were reported in the same study only twice and of these only once in same ecosystem (Castillo et al. 2006; Bashan et al. 2007). Additional evidence from the INVAM culture collection verifies the rarity of Ar. schenckii. Of the 27 Ar. trappei cultures in INVAM, only a single Ar. schenckii strain (CL401) has been submitted to the collection. Rarity of both phenotypes in the same isolate was also limited to intact immature spores from culture of CL401 (this study). The presence of both phenotypes can easily be missed in field-collected samples or overlooked if expressed at a low frequency in cultures due to degradation of outer layer, which sloughs and separates spore from the sporiferous saccule.

Taxonomically informative characters significant across all Glomeromycota for ranking genera and species were found in the spore subcellular structures in the former, and in the individual layers within the spore wall in the latter (Morton 1990). In Acaulospora, all species regardless of mode of spore formation have a bi- or tri-layered spore wall, two bilayered flexible inner germinal walls, and a germination orb that develops on the inner most germinal walls (Morton 1990; Stürmer \& Morton 1999; Kaonongbua et al. 2010). In Ambispora, spores have a tri-layered spore wall and a thick semi-pliable inner wall with a variable number of sublayers (Morton et al. 1997; Morton \& Redecker 2001; Bills \& Morton 2015). In Archaeospora, both spore subcellular phenotypes of Ar. trappei are indistinguishable containing a simple, hyaline bilayered spore wall and a thicker flexible inner wall.

Phylogenetic reconstruction of Ar. trappei LSU sequences revealed population-level variants that diverged into two deeply lineages, with greater genetic distance between subclades than distances between species clades. The magnitude of the branch lengths suggests enough divergence exists to reclassify either Ar. trappei subclade as a new species. Although, other AMF have been shown to harbor highly polymorphic rDNA sequences. For example, VanKuren et al. (2013) showed clear evidence of divergent LSU gene evolution within single spores from globally distributed isolates of three Claroideoglomus species. Two distinct rRNA gene types, a long and a short type, were detected together within individual spores. Phylogenetic reconstructions showed the long and short type of sequences clustered together in two distinct 
clades represented by sequences from all three species. Copies of both variants were found to exist in high copy number within individual nuclei and FISH analysis revealed both variants were close together but spatially separated within the same nucleoli.

One explanation for retention of polymorphic rRNA loci in Claroideoglomus spores physical separation of sequence types in the nucleoli inhibited homogenizing mechanisms of concerted evolution (vanKuren et al. 2013). A mechanism that explains the retention of divergent Ar. trappei sequences is not known. Our data did not detect both sequence types together within single spores, but both subclades were equally represented among geographically distinct isolates. A broader sampling of 13 clones from a single spore from South Africa (isolate SF119B) revealed identical sequences with North American isolates from North Carolina (NC105B) and Florida (FL327) indicating rRNA gene variants are highly conserved. A similar pattern also was observed within geographically differentiated isolates of Paraglomus occultum (This study; Colombian isolate CL700 and Florida isolate FL703), and within sequence variants of Claroideoglomus claroideum/Claroideogloum luteum and Claroideoglomus etunicatum (vanKuren et al. 2013). Identical polymorphisms in Ar. trappei shared across globally distinct isolates suggests fixation of these variants early in an ancestral population before descendant populations were separated due to a vicariance event such as continental movements (Baum \& Smith 2013). The presence of minor intra-individual and intra-population LSU polymorphisms within each subclade suggest low rates of mutation occurred faster than localized homogenization of neighboring gene copies (VanKuren et al. 2013).

Our phylogenetic analysis indicates that evolutionary patterns in the ancestral clade Archaeospora in the Glomeromycota is much more complex than previously thought. The combined analysis of LSU gene sequence data in conjunction with analysis of the simple, spore wall subcellular characters indistinguishable between the two morphotypes has provided a powerful approach for testing hypotheses of evolutionary relationships and species boundaries in the Glomeromycota (Morton \& Redecker 2001; Walker et al. 2007; Morton 2009; Kaonongbua et al. 2010; Morton \& Msiska 2010a, 2010b; Krüger et al. 2011; Oehl et al. 2011; Schüßler et al. 2011; Redecker et al. 2013; Bills \& Morton 2015). Effective use of comparative morphology and molecular data for classifying taxa relies on a broad sampling of specimens, in order to identify shared derived characters (snyapomorphies), and prevents misinterpretation of population-level variation as species variation (Hillis 1987; Davis \& Nixon 1992; Morton 2009; Msiska \& Morton 
2009a; Morton \& Msiska 2010a; Redecker et al. 2013; Bills \& Morton 2015). Phenotypic differences that are the product of mutation events fixed readily because of clonal reproduction in populations must be excluded, and current gene sequence analysis contributes to exposing these traits (Kaonongbua et al. 2010; Morton \& Msiska 2010a; Kruger et al. 2011; Bills \& Morton 2015).

\section{Acknowledgements}

Funding support was provided by the National Science Foundation grants DBI0650735 and DEB069341. The authors wish to thank Bill Wheeler for assistance in maintaining and processing of AMF cultures. Ellie Spahr and Jessica Frank (both at West Virginia University) generated sequences for this publication. We thank Dr. W. Kaonongbua and Dr. J. Bever for

CL401 voucher and single spore culture 4 (ss4). We also thank Dr. D. Ford-Werntz (curator of the WVU Herbarium), and Dr. R. Halse (curator Oregon State University Herbarium). 
Table 1 - Estimates of evolutionary divergence (standard error) between groups of partial LSU rDNA sequences from deeply rooted taxa in Glomeromycota. Groups compared included both Archaeospora trappei subclades, Ar. schenckii, Ambispora gerdemannii, Am. leptoticha, Paraglomus brasilianum, and P. occultum. The average distance was calculated from the arithmetic mean of all pairwise distances between groups in the inter-group comparisons. Analysis conducted in MEGA6 using the Kimura 2-parameter model + gamma (gamma distribution $=4$ ).

\begin{tabular}{llllllll}
\hline Clade group & $\begin{array}{l}\text { Ar. trappei } \\
\text { subclade-1 }\end{array}$ & $\begin{array}{l}\text { Ar. trappei } \\
\text { subclade-2 }\end{array}$ & Ar. schenckii & Am. leptoticha & Am. gerdemannii & P. occultum & $P$. brasilianum \\
\hline${ }^{\mathrm{a}}$ Ar. trappei sub-1 & $\mathrm{XX}$ & $0.168(0.016)$ & $0.168(0.017)$ & $0.270(0.025)$ & $0.268(0.025)$ & $0.317(0.025)$ & $0.318(0.026)$ \\
${ }^{\mathrm{b}}$ Ar. trappei sub-2 & & $\mathrm{XX}$ & $0.030(0.004)$ & $0.254(0.023)$ & $0.267(0.025)$ & $0.357(0.027)$ & $0.339(0.027)$ \\
${ }^{\mathrm{c}}$ Ar. schenckii & & & $\mathrm{XX}$ & $0.259(0.024)$ & $0.270(0.026)$ & $0.366(0.026)$ & $0.340(0.028)$ \\
${ }^{\mathrm{d}}$ Am. leptoticha & & & $\mathrm{XX}$ & $0.069(0.010)$ & $0.289(0.025)$ & $0.292(0.025)$ \\
${ }^{\mathrm{d}}$ Am. gerdemannii & & & & $\mathrm{XX}$ & $0.284(0.023)$ & $0.287(0.024)$ \\
${ }^{\mathrm{e}}$ P. occultum & & & & & $\mathrm{XX}$ & $0.111(0.012)$ \\
\hline
\end{tabular}

${ }^{\mathrm{a}}$ Ar. trappei subclade-1 = Archaeospora trappei INVAM isolates FL327C, KE120, NC104B, SF119B; ${ }^{\mathrm{b}}$ Ar. trappei subclade-2 $=$ Archaeospora trappei INVAM isolates AU219, AZ119; IL203B, ON201D, PE102, SF113 and NCBI accessions FR750034-

FR750038; ${ }^{\mathrm{c}}$ Ar. schenckii = Archaeospora schenckii single spore isolates from INVAM strain CL401 and NCBI accessions

FR750020-FR750023; ${ }^{\mathrm{d}}$ Am = Ambispora $;{ }^{\mathrm{e}} \mathrm{P} .=$ Paraglomus isolates. Evolutionary analyses conducted in MEGA6 (Tamura et al . 2013). 
Table 2 - A summary of spore size and subcellular diagnostic characters of Archaeospora schenckii and Archaeospora trappei reported in previous studies.

\begin{tabular}{|c|c|c|c|c|c|c|}
\hline $\begin{array}{l}\text { Authors } \\
\text { taxa described }\end{array}$ & $\begin{array}{l}\text { Spore diameter } \\
(\mu \mathrm{m})\end{array}$ & Spore shape & $\begin{array}{l}\text { Saccule } \\
\text { diameter }(\mu \mathrm{m})\end{array}$ & $\begin{array}{l}\text { Spore wall } \\
\text { characteristics }\end{array}$ & $\begin{array}{l}\text { Outer } \\
\text { structure }(\mu \mathrm{m})\end{array}$ & $\begin{array}{l}\text { Inner structure \& } \\
\text { thickness }(\mu \mathrm{m})\end{array}$ \\
\hline \multicolumn{7}{|l|}{ Ames \& Linderman 1976} \\
\hline Acaulospora trappei & $42-99 \times 42-72$ & $\begin{array}{l}\text { globose, ellipsoid, } \\
\text { obovoid }\end{array}$ & $50-82 \times 42-72$ & 1 wall & $\begin{array}{l}1 \text { layer } \\
1.2-2.3\end{array}$ & No inner wall \\
\hline $\begin{array}{l}\text { Sieverding \& Toro } 1987 \\
\quad \text { Entrophospora schenckii }\end{array}$ & $\begin{array}{l}(37-) 50-60(-77) \\
\text { or } 48-97 \times 25-60\end{array}$ & $\begin{array}{l}\text { globose, subglobose } \\
\text { or ellipsoid, ovoid }\end{array}$ & $(37-) 50-60(-77)$ & 2 components & $\begin{array}{l}1 \text { component, } \\
0.5-1.0\end{array}$ & $\begin{array}{l}2 \text { components } \\
0.4-1.0,1.5-2.0\end{array}$ \\
\hline $\begin{array}{c}\text { Morton \& Redecker } 2001 \\
\text { Archaeospora trappei }\end{array}$ & $40-80$ & $\begin{array}{l}\text { globose, subglobose, } \\
\text { irregular }\end{array}$ & $40-48 \times 50-72$ & 3 layers & $\begin{array}{l}\text { layer } 1 \\
1.0-1.2\end{array}$ & $\begin{array}{l}2 \text { layers } \\
<0.5-0.7,1.3-2.5\end{array}$ \\
\hline $\begin{array}{l}\text { Fracchia et al. } 2003 \\
\quad \text { Entrophospora schenckii }\end{array}$ & $(49-) 50-60(-72)$ & globose, subglobose & $50-60$ & 3 layers & $\begin{array}{r}1 \text { layers } \\
0.5-1.0\end{array}$ & $\begin{array}{l}2 \text { layers } \\
0.4-1.0,1.5-2.0\end{array}$ \\
\hline $\begin{array}{l}\text { Spain } 2003 \\
\quad \text { Archaeospora trappei }\end{array}$ & n.d. & n.d. & n.d. & 2 walls & $\begin{array}{l}2 \text { layers } \\
0.5,1.0\end{array}$ & $\begin{array}{l}4 \text { layers } \\
<0.5,1.5-2.0,<0.5,0.5\end{array}$ \\
\hline $\begin{array}{l}\text { Hafeel } 2004 \\
\text { Archaeospora trappei }\end{array}$ & $82 \times 95$ & Mostly globose & $68-101$ & 2 components & $\begin{array}{l}1 \text { layer } \\
1.0-2.0\end{array}$ & $\begin{array}{l}2 \text { layers } \\
0.5-1.0,1.5-3.0\end{array}$ \\
\hline $\begin{array}{c}\text { Sieverding \& Oehl } 2006 \\
\text { Intraspora schenckii }\end{array}$ & $45-75$ & $\begin{array}{l}\text { Globose, subglobose, } \\
\text { oblong }\end{array}$ & n.d. & $\begin{array}{l}2 \text { walls, } \\
\text { multiple layers }\end{array}$ & $\begin{array}{l}2 \text { layers } \\
\text { n.d. }\end{array}$ & $\begin{array}{l}3 \text { "spore wall layers" } \\
\text { n.d. }\end{array}$ \\
\hline $\begin{array}{l}\text { Walker et al. } 2007 \\
\text { Archaeospora trappei } \\
\text { Intraspora schenckii }\end{array}$ & $\begin{array}{l}40-48 \times 50-72 \\
40-48 \times 50-72\end{array}$ & $\begin{array}{l}\text { n.d. } \\
\text { n.d. }\end{array}$ & $\begin{array}{l}\text { n.d. } \\
\text { n.d. }\end{array}$ & $\begin{array}{l}2 \text { walls } \\
2 \text { walls }\end{array}$ & $\begin{array}{l}1 \text { component } \\
\text { n.d }\end{array}$ & $\begin{array}{l}\text { bilayered component } \\
\text { n.d. }\end{array}$ \\
\hline
\end{tabular}

n.d.= no data reported. 
Fig 1 - MrBayes phylogenetic tree reconstructed from partial 28S (LSU) gene sequences using the Kimura 2 parameter plus gamma $(\mathrm{K} 2 \mathrm{P}+\mathrm{G})$ model. Maximum likelihood (ML) tree had identical topology. Bayesian posterior probabilities greater than 0.97 are depicted by thickened branches, and ML bootstrap values greater than $70 \%$ are designated above the branches. Branch labels sequentially specify: source material, INVAM accession and (NCBI accession number). All new sequences Ar. schenckii CL401 sequences were generated from four single spore strains (ss1, ss2, ss3 or ss4). The tree was rooted by Geosiphon pyriformis. 


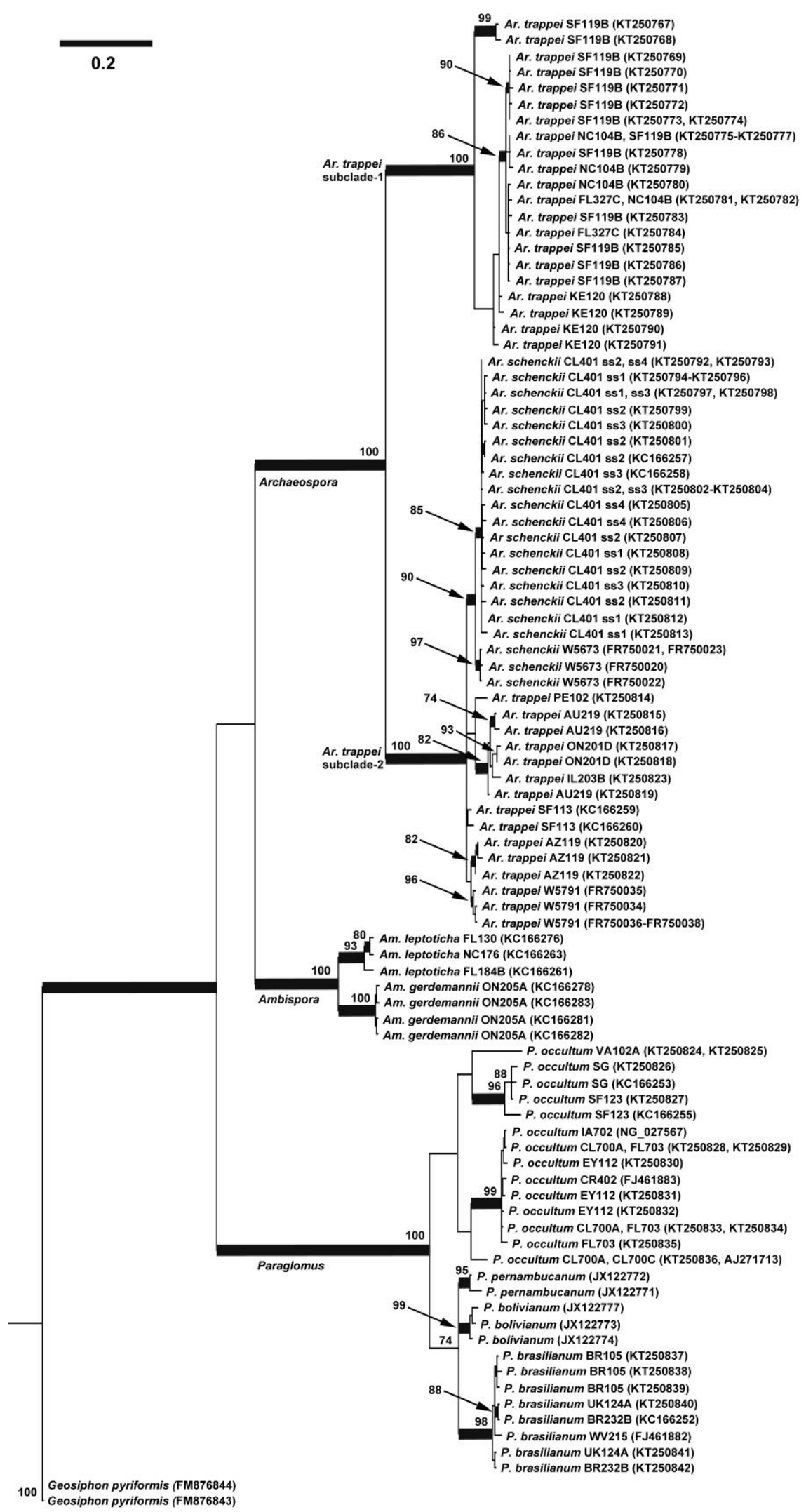


Fig 2 - Equivalence in comparative spore morphology of Archaeospora trappei that develop from the hypha of a precursor sporiferous saccule, either laterally (acaulosporoid) or internally (entrophosporoid). Spores are hyaline, with a thin semi-flexible outer spore wall layer ( $L 1)$, a more permanent, semiflexible second layer $(L 2)$ and a thicker flexible, finely laminate inner wall $(i w)$ that form wrinkles and folds in crushed spores. The outer spore wall layer $(L 1)$ is continuous with the wall of the sporiferous saccule and subtending hyphal wall. Cicatrices, circular ridges or scars, may be detected at points of contact with the hypha subtending the saccule. Whole spores from Ar. trappei NB112 in water showing variation in acaulosporoid phenotype (A). Juvenile acaulosporoid spore (SP) forming laterally from the hypha subtending $(\mathrm{SH})$ a sporiferous saccule (SS) from CL401 (B). Intact acaulosporoid spore with outer spore wall layer (L1) continuous with hyphal wall subtending a sporiferous saccule with fully differentiated second layer $(L 2)$ and inner wall $(i w)$ from JA101C (C). Variation in acaulosporoid spore outer layer $(L 1)$ and hypha subtending a sporiferous saccule from AZ119A (D). Differentiated acaulosporoid spore with partially degraded spore wall outer layer $(L 1)$ and missing diagnostic hypha subtending a sporiferous saccule from MX116 (E). Juvenile entrophosporoid spore (SP) forming within the hypha subtending (SH) a sporiferous saccule (SS) from CL401 (F). Intact entrophosporoid spore within the hypha $(L 1)$ subtending a sporiferous saccule with second layer of the spore wall $(L 2)$ and inner wall $(i w)$ from CL401 (G). Variation in differentiated entrophosporoid spore with partially degraded outer spore wall layer (L1) from CL401 (H). Differentiated entrophosporoid spore with partially degraded outer spore wall layer $(L l)$ and missing diagnostic subtending hypha and saccule from CL401 (I). Bar A represents $100 \mu \mathrm{m}$ Bars B-I represents $5 \mu \mathrm{m}$. 


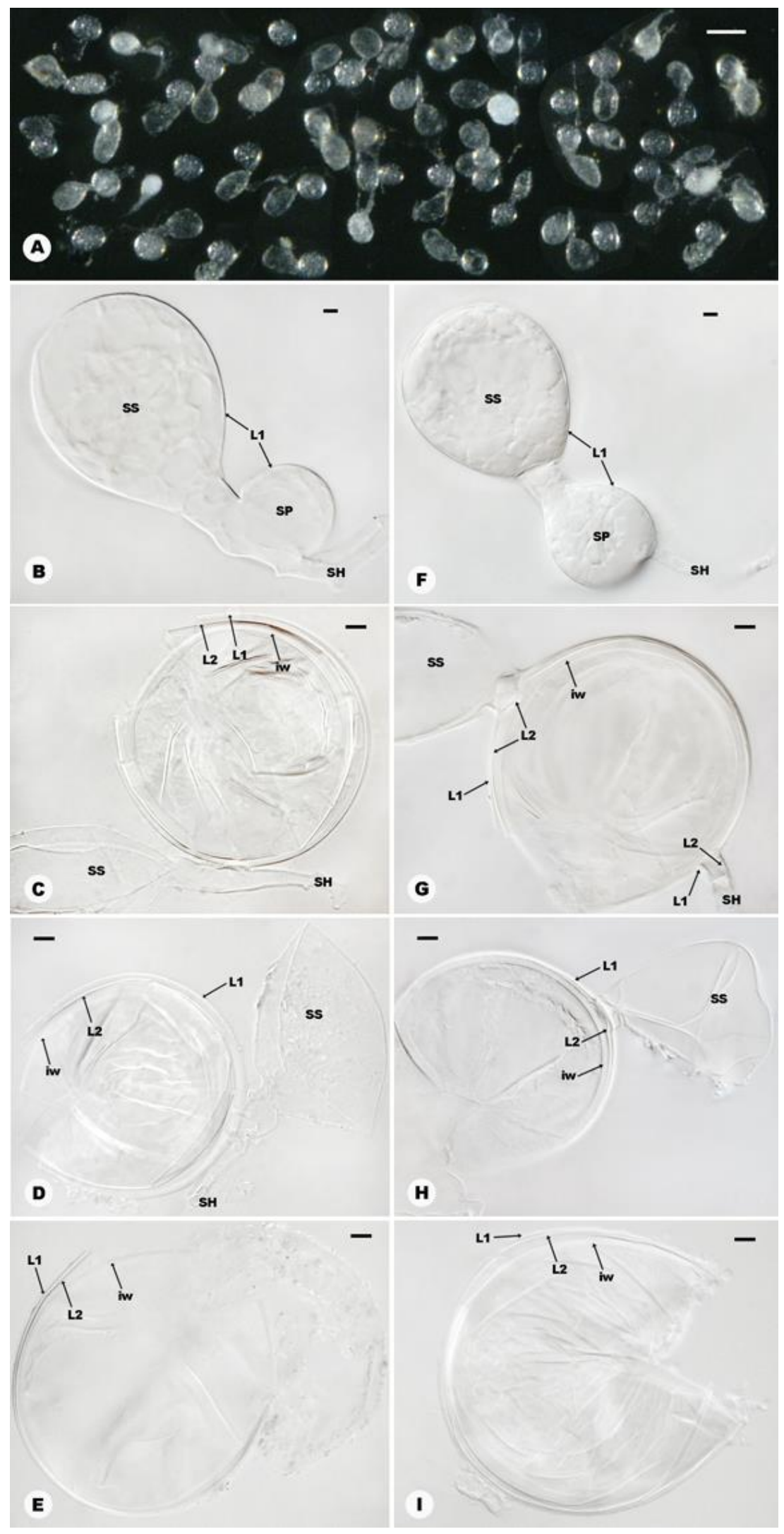




\section{REFERENCES}

Ames RN, Linderman RG, 1976. Acaulospora trappei sp. nov. Mycotaxon 3: 565-569.

Ames RN, Schneider RW, 1979. Entrophospora, a new genus in the Endogonaceae. Mycotaxon 8: $347-352$.

Bashan Y, Khaosaad T, Salazar BG, Ocampo JA, Wiemken A, Oehl F, Vierheilig H, 2007. Mycorrhizal characterization of the boojum tree, Fouquieria columnaris, an endemic ancient tree from the Baja California Peninsula, Mexico. Trees 21: 329-335.

Bills RB, Morton JB, 2015. A combination of morphology and 28S rRNA gene sequences provide grouping and ranking criteria to merge eight into three Ambispora species (Ambisporaceae, Glomeromycota). Mycorrhiza. doi:10.1007/s00572-015-0626-7.

Boon E, Zimmerman E, Lang BF, Hijri M, 2010. Intra-isolate genome variation in arbuscular mycorrhizal fungi persists in the transcriptome. Journal of Evolutionary Biology 23: 1519-1527.

Castillo CG, Borie F, Godoy R, Rubio R, Sieverding E, 2006. Diversity of mycorrhizal plant species and arbuscular mycorrhizal fungi in evergreen forest, deciduous forest and grassland ecosystems of Southern Chile. Journal of Applied Botany and Food Quality 80: 40-47.

Davis JL, Nixon KC, 1992. Populations, genetic variation, and the delimitation of phylogenetic species. Systematic Biology 41: 421-435.

Edgar RC, 2004. MUSCLE: a multi sequence alignment method with reduced time and space complexity. BMC Bioinformatics 5: 1-19.

Fracchia S, Scervino JM, Menéndez A, Godeas A, 2003. Isolation, culture and host colonization of Entrophospora schenckii (Glomales), an arbuscular mycorrhizal fungus. Nova Hedwigia 77: 383-388.

Hafeel KM, 2004. Spore ontogeny of the arbuscular mycorrhizal fungus Archaeospora trappei (Ames \& Linderman) Morton \& Redecker (Archaeosporaceae). Mycorrhiza 14: 213-219.

Hillis DM, 1987. Molecular versus mophologica approaches to systematics. Annual Review of Ecological Systematics 18: 23-42.

Kaonongbua W, Morton JB, Bever JD, 2010. Taxonomic revision transferring species in Kuklospora to Acaulospora (Glomeromycota) and a description of Acaulospora colliculosa sp. nov. from field collected spores. Mycologia 102: 1497-1509. doi:10.3852/10-011. 
Kimura M, 1980. A simple method for estimating evolutionary rate of base substitutions through comparative studies of nucleotide sequences. Journal of Molecular Evolution 16: 111-120. Koske RE, Tessier B, 1983. A convenient, permanent slide mounting medium. Mycological Society of America Newsletter 34: 59.

Krüger M, Krüger C, Walker C, Stockinger H, Schüßler A, 2012. Phylogenetic reference data for systematics and phylotaxonomy of arbuscular mycorrhizal fungi from phylum to species level. New Phytologist 193: 970-984.

Krüger M, Walker C, Schüßler A, 2011. Acaulospora brasiliensis comb. nov. and Acaulospora alpina (Glomeromycota) from upland Scotland: morphology, molecular phylogeny and DNAbased detection in roots. Mycorrhiza 21: 577-587.

Librado P, Rozas J, 2009. DnaSP v5: a software for comprehensive analysis of DNA polymorphism data. Bioinformatics 25: 1451-1452.

Morton JB, 1988. Taxonomy of VA mycorrhizal fungi: classification, nomenclature, and identification. Mycotaxon 32: 267-324.

Morton JB, 1990. Evolutionary relationships among arbuscular mycorrhizal fungi in the Endogonaceae. Mycologia 82: 192-207.

Morton JB, 2009. Reconciliation of conflicting phenotypic and rRNA gene phylogenies of fungi in Glomeromycota based on underling patterns and processes. In: Azcon-Aguilar C, Barea JM, Gianinazzi S, Gianinazzi-Pearson V (eds), Mycorrhizas - functional processes and ecological impact. Springer-Verlag, Berlin, pp. 137-154. doi:10.1007/978-3-540-87978-7.

Morton JB, Benny GL, 1990. Revised classification of arbuscular mycorrhizal fungi (Zygomycetes): a new order, Glomales, two new suborders, Glomineae and Gigasporineae, and two new families, Acaulosporaceae and Gigasporaceae, with an emendation of Glomaceae. Mycotaxon 37: 471-491.

Morton JB, Bentivenga SP, Wheeler WW, 1993. Germplasm in the International Collection of Arbuscular and Vesicular-arbuscular Mycorrhizal Fungi (INVAM) and procedures for culture and development, documentation and storage. Mycotaxon 48: 491-528.

Morton JB, Bever JD, Pfleger F, 1997. Taxonomy of Acaulospora gerdemannii and Glomus leptotichum, synanamorphs of an arbuscular mycorrhizal fungus in the Glomales. Mycological Research 101: 625-631. 
Morton JB, Franke M, Bentivenga SP, 1995. Developmental foundations for morphological diversity among endomycorrhizal fungi in Glomales (Zygomycetes). In: Varma A, Hock B (eds), Mycorrhiza: structure, function, molecular biology and biotechnology. Springer, Berlin Heidelberg New York.

Morton JB, Msiska Z, 2010a. Ontogeny and phylogeny of a Scutellospora heterogama mutant, with implications for morphological recognition of species in Glomeromycota. Fungal Biology 114: $410-420$.

Morton JB, Msiska Z, 2010b. Phylogenies from genetic and morphological characters do not support a revision of Gigasporaceae (Glomeromycota) into four families and five genera. Mycorrhiza 20: 483-496. doi:10.1007/s00572-010-0303-9.

Morton JB, Redecker D, 2001. Two new families of Glomales, Archaeosporaceae and Paraglomeraceae, with two new genera Archaeospora and Paraglomus, based on concordant molecular and morphological characters. Mycologia 93: 181-195.

Msiska Z, Morton JB, 2009a. Isolation and sequence analysis of a $\beta$-tubulin gene from arbuscular mycorrhizal fungi. Mycorrhiza 19: 501-513.

Msiska Z, Morton JB, 2009b. Phylogenetic analysis of the Glomeromycota by partial $\beta$-tubulin gene sequences. Mycorrhiza 19: 247-254.

Nei M, Kumar S, 2000. Molecular Evolution and Phylogenetics. New York, Oxford University Press.

Oehl F, da Silva AG, Sánchez-Castro I, Goto BT, Maia LC, Vieira HEE, Barea J-M, Sieverding E, Palenzuela J, 2011. Revision of Glomeromycetes with entrophosporoid and glomoid spore formation and three new genera. Mycotaxon 117: 297-316.

Page RDM, Holmes EC, 2006. Molecular Evolution A Phylogenetic Approach. Blackwell Publishing, Malden, MA, USA.

Palenzuela J, Barea JM, Ferrol N, Azcon-Aguilar C, Oehl F, 2010. Entrophospora nevadensis, a new arbuscular mycorrhizal fungus from Sierra Nevada Park (southwestern Spain). Mycologia 102: $624-632$.

Pollack DD, Zwickl DJ, McGuire JA, Hillis DM, 2002. Increased taxon sampling is advantageous for phylogenetic inference. Systematic Biology 51: 664-671. 
Redecker D, Morton JB, Bruns TD, 2000. Ancestral lineages of arbuscular mycorrhizal fungi (Glomales). Molecular Phylogenetics and Evolution 14: 276-284.

Redecker D, Schüßler A, Stockinger H, Stürmer SL, Morton JB, Walker C, 2013. An evidencebased consensus for the classification of arbuscular mycorrhizal fungi (Glomeromycota). Mycorrhiza. doi:0.1007/s00572-013-0486-y.

Ronquist F, Teslenko M, Van Der Mark P, Ayres DL, Darling A, Höhna S, Larget B, Liu L, Suchard MA, Huelsenbeck JP, 2012. MrBayes 3.2: efficient Bayesian phylogenetic inference and model choice across a large model space. Systematic Biology 61: 539-542. http://mrbayes.net.

Rosendahl S, Mcgee P, Morton JB, 2009. Lack of global population genetic differentiation in the arbuscular mycorrhizal fungus Glomus mosseae suggests a recent range expansion which may have coincided with the spread of agriculture. Molecular Ecology 18: 4316-4329.

Schnare MN, Damberger SH, Gray MW, Gutell RR, 1996. Comprehensive comparison of structural characteristics in eukaryotic cytoplasmic large subunit (23 S-like) ribosomal RNA. Journal of Molecular Biology 256: 701-719.

Schüßler A, Walker C, 2010. The Glomeromycota: a species list with new families and new genera. Arthur Schüßler \& Christopher Walker, Gloucester. Published in December 2010 in libraries at The Royal Botanic Garden Edinburgh, The Royal Botanic Garden Kew, Botanishce Staatssammlung Munich, and Oregon State University. Printed copy available under ISBN-13: 978-1466388048, ISBN-10: 1466388048. Available at http://www.amf-phylogeny.com.

Schüßler A, Krüger M, Walker C, 2011. Revealing natural relationship amongst arbuscular mycorrhizal fungi: culture line BEG47 represents Diversispora epigaeae, not Glomus versiforme. PLoS One 6: e23333

Schüßler A, Schwarzott D, Walker C, 2001. A new fungal phylum, the Glomeromycota: phylogeny and evolution. Mycological Research 105: 1413-1421.

Sieverding E, Oehl F, 2006. Revision of Entrophospora and description of Kuklospora and Intraspora, two new genera in the arbuscular mycorrhizal Glomeromycetes. Journal of Applied Botany and Food Quality 80: 69-81.

Sieverding E, Toro T, 1987. Entrophospora schenckii: a new species in the Endogonaceae from Colombia. Mycotaxon 38: 209-214. 
Spain JL, 2003. Emendation of Archaeospora and of its type species, Archaeospora trappei. Mycotaxon 88: 109-112.

Stockinger H, Krüger M, Schüßler A, 2010 DNA barcoding of arbuscular mycorrhizal fungi. New Phytologist 187: 461-474.

Stockinger H, Peyret-Guzzon M, Koegel S, Bouffaud M-L, Redecker D, 2014. The largest subunit of RNA polymerase II as a new marker gene to study assemblages of arbuscular mycorrhizal fungi in the field. PLOS One 9. DOI: e107783.

Stürmer SL, Morton JB, 1999. Taxonomic reinterpretation of morphological characters in Acaulosporaceae based on developmental patters. Mycologia 91: 849-857.

Tamura K, Stecher G, Peterson D, Kumar S, 2013. MEGA6: Molecular evolutionary genetic analyses version 6.0. Molecular Biology and Evolution 30: 2725-2729.

Thiéry O, Moora M, Vasar M, Zobel M, Öpik M, 2012. Inter- and intersporal nuclear ribosomal gene sequence variation within one isolate of arbuscular mycorrhizal fungus, Diversispora sp. Symbiosis 58: 135-147.

Trouvelet S, van Tuinen D, Hijri M, Gianinazzi-Pearrson V, 1999. Visualization of ribosomal DNA loci in spore interphasic nuclei of glomalean fungi by fluorescence in situ hybridization. Mycorrhiza 8: 203-206.

van der Heijden MGA, Scheublin TR, Brader A, 2004. Taxonomic and functional diversity in arbuscular mycorrhizal fungi: Is there any relationship? New Phytologist 164: 201-204.

VanKuren NW, den Bakker HC, Morton JB, Pawlowska TE, 2013. Ribosomal RNA gene diversity, effective population size, and evolutionary longevity in asexual Glomeromycota. Evolution 67: 207-224.

van Tuinen D, Zhao B, V Gianinazzi-Pearson V, 1998. PCR in studies of AM fungi: from primers to application. In: Varma A (ed), Mycorrhiza Manual. Springer-Verlag, Berlin, pp. 337399.

Walker C, Vestberg M, Demircik F, Stockinger H, Saito M, Sawaki H, Nishmura I, Schüßler A, 2007. Molecular phylogeny and new taxa in the Archaeosporales (Glomeromycota): Ambispora fennica gen. sp. nov., Ambisporaceae fam. nov., and emendation of Archaeospora and Archaeosporaceae. Mycological Research 111: 137-153.

White T, Bruns T, Lee S, Taylor J, 1990. Amplification and Direct Sequencing of Fungal Ribosomal RNA Genes for Phylogenetics. In: Innis MA, Gelfand DH, Sninsky JJ, White JW 
(eds), PCR Protocols: a guide to methods and applications. Academic Press Inc, San Diego, California, pp. 315-322. 


\section{CONCLUSIONS}

A combination of morphological analysis of type specimens and live cultures and phylogenetic analysis of $28 \mathrm{~S}$ rDNA (LSU) sequences was used to provide grouping and ranking criteria to merge species in Ambispora (Ambisporaceae) and Archaeospora (Archaeosporaceae).

Independent morphological and molecular data sets provided important criteria for distinguishing homologous characters that informed on common ancestry and exposed convergent characters that were not phylogenetically informative. Based on these combined data, four species (Am. appendicula, Am. callosa, Am. fecundispora, and Am. jimgerdemannii) were merged into Am. leptoticha; Am. fennica was merged into Am. gerdemannii; and Ar. schenckii was merged into Ar. trappei. The one other species in Ambispora, Am. granatensis, had a unique morphology and molecular signature but also shared the same phylogenetic patterns as three species in Claroideoglomus. Combined morphological and LSU data sets clarified species grouping and ranking criteria when given equal treatment. Glomoid spores in Ambispora provided resolution only at the genus level, whereas spore wall inner layers of acaulosporoid and entrophosporoid spores resolved species. Evolution of a sporogenous saccule was a convergent trait that evolved separately in Ambispora, Archaeospora, and in other AMF families.

LSU gene phylogeny from single spores of living cultures affirmed that spores produced by Ambispora and Archaeospora have the potential to be dimorphic. LSU sequences also produced divergent subclades within monophyletic groups that could be ranked definitively by the combination of morphological and molecular characters. Results from both studies show that rRNA genes in Glomeromycota are polymorphic, sometimes with sequence divergence within species equivalent to that between species of some AMF genera. The fixation of morphological and molecular characters in some populations may be explained by mutation events fixed rapidly due to genetic isolation and asexual mode of reproduction in haploid clonal organisms. The processes affecting the dynamics of polymorphic rRNA lineages within and among asexual species is poorly understood but encourages the search for other independent gene lineages that will clarify the biology and evolutionary relationships in Glomeromycota. 


\section{CURRICULUM VITAE}

ROBERT J. BILLS

robertjbills@gmail.com • 304-931-4288

21 Highland St. Apt 4 - Westover, West Virginia 26501

\section{EDUCATION}

2015 (anticipated) Ph.D. candidate Plant and Soil Sciences

West Virginia University, Morgantown, West Virginia

Dissertation Title: A combination of morphology and LSU gene phylogeny to reclassify species in the Archaeosporales (Glomeromycota). Advisor: Dr. Joseph Morton

2006

M.S. Plant Biology

Arizona State University, Tempe, Arizona

Thesis Title: Mycorrhizal diversity and effects on brittlebush in a Sonoran Desert urban ecosystem. Advisor: Dr. Jean Stutz

1997

B.S. Biology, cum laude

Arizona State University, Tempe, Arizona

\section{RESEARCH EXPERIENCE}

2007-2015 Graduate Research Assistant, West Virginia University, Morgantown, WV.

- $\quad$ Experience with molecular and morphological characterization of undescribed and described species of arbuscular mycorrhizal fungi (AMF) stored in the International Culture Collection of Arbuscular Mycorrhizal Fungi (INVAM). Isolated, cultured and contributed more than 20 AM fungal species to the INVAM collection.

- $\quad$ Experience with maintenance of live AM fungal cultures and growing host plants in greenhouse and growth room environments. Hands-on experience using standard aseptic techniques working with soil micro-organisms.

- Hands-on experience developing methods for AMF spore extraction from cultures, DNA extraction, PCR, cloning, plasmid DNA preparation for sequencing, rDNA sequence alignments, and phylogenetics. Contributed more than 200 partial LSU rDNA gene sequences to the INVAM database. Experience using standard molecular aseptic techniques working with DNA.

- Hands-on experience in use of Nikon Eclipse E600 microscope equipped with DIC optics, Nikon DS-Ri1 digital camera and NIS-Elements imaging software.

- $\quad$ Experience training multicultural staff, international visitors, graduate and undergraduate students in microscope, molecular and fungal propagation methods.

2006-2007 Research Technician, USDA Systematic Botany and Mycology Laboratory, Beltsville, MD. 
- Experience with DNA extraction, PCR amplification and sequencing of plant pathogenic fungi.

2003-2006 Graduate Research Assistant, Arizona State University, Tempe, AZ

- Experience collecting, culture and identification of arbuscular mycorrhizal fungi.

- Experience with collection of soil and vegetation samples, data analysis, and data entry in conjunction with Phoenix, Arizona Long-term Ecological Research project (LTER).

- Experience with multi-team of scientists, ability to conduct independent research with plants, experimental design and statistical analyses.

\section{TEACHING EXPERIENCE}

2011, 2014- Graduate Teaching Assistant, Instructor Principles of Biology Lab and

2015 Introductory Physiology Lab, Department of Biology, West Virginia University, Morgantown, WV

- Experience teaching biology majors (160 students) the scientific method for hypothesis testing, experimental design, data collection, analysis, interpretation of data, and scientific writing.

- Hands-on experience teaching aseptic techniques, use of spectrophotometer, creation of a standard curve, bacterial transformation, protein extraction, PCR, gel electrophoresis, plant propagation and nutrient deficiency, phylogenetics, and bacterial transformation.

2012-2013 Graduate Teaching Assistant, Principles of Plant Science Lab, Department of Plant Pathology, West Virginia University, Morgantown, WV

- Experience teaching principles of plant science with hands-on microscope and greenhouse activities (144 students).

- Experience leading students in monitoring growth of four agronomic and horticulture crop species through complete life cycles.

Spring 2007 Instructor, Introductory Biology and Introductory Biology Lab, Department of Life Sciences, Northern Virginia Community College, Sterling, VA

\section{MEMBERSHIPS}

2009-present International Mycorrhizal Society 


\section{PUBLICATIONS}

Bills RJ, Morton JB, in prep. Morphology and an LSU phylogeny reveal Archaeospora trappei and $A r$. schenckii are synonymous and mode of spore formation resolves only stable populationlevel variation.

Bills RJ, Morton JB, 2015. Morphology and 28S rRNA gene sequences provide grouping and ranking criteria to merge eight into three Ambispora species (Ambisporaceae, Glomeromycota). Mycorrhiza 25(6): 485-498. doi:10.1007/s00572-015-0626-7.

Bills RJ, Stutz JC, 2007. AMF associated with indigenous and non indigenous plants at urban and desert sites in Arizona. Pages 207-220 In: Mycorrhizas - Functional Processes and Ecological Impact. (eds) C. Azcón-Aguilar, J.M. Barea, S. Gianinazzi, and V. GianinazziPearson. Springer-Verlag. Heidelberg.

\section{PRESENTATIONS}

Bills RJ, Stutz JC. Building a research experience: From morphotyping species of arbuscular mycorrhizae in and around Phoenix, Arizona to the molecular analysis of rust fungi from around the world. Systematic Botany and Mycology Laboratory, USDA Beltsville, MD. May 30, 2007

Bills RJ, Stutz JC. Arbuscular mycorrhizal fungal community associated with indigenous and non-indigenous plants in and around a desert city. Mid-Atlantic States Mycological Congress Beltsville, MD April 21, 2007

Bills RJ, Stutz JC. Arbuscular mycorrhizal fungal community associated with indigenous and non-indigenous plants in and around Phoenix, Arizona USA. $5^{\text {th }}$ International Conference on Mycorrhiza, Granada, Spain. July 23-27, 2006.

Bills RJ. Mycorrhizal diversity and effects on brittlebush at a Sonoran Desert urban ecosystem. Thesis defense, Arizona State University, Tempe, Arizona. May 15, 2006.

Bills RJ. Effects of arbuscular mycorrhizal suppression on the productivity of Encelia farinosa (brittlebush) at an urban and a desert site. Global Institute for Sustainability, Arizona State University, Tempe, Arizona. November 14, 2005.

Bills RJ. Arbuscular mycorrhizal fungi: a fungal-plant mutualism in the upper Sonoran Desert and Phoenix, Arizona. Ecology Explorers K-12 Teacher Training Workshop, International Institute for Sustainability, Arizona State University, Tempe, AZ. June 28, 2005. 
Bills RJ. Arbuscular mycorrhizal fungi in Phoenix: the fungal infection that doesn't itch. School of Life Sciences Graduate Student Brown Bag Seminar, Arizona State University, Tempe, AZ. April 1, 2005

Bills RJ. Arbuscular mycorrhizal fungi and the changing biodiversity between the Sonoran Desert and the Phoenix metropolitan area. 6th Annual Graduates in Earth, Life, and Social Sciences (GELSS) Research Symposium, Arizona State University, Tempe, AZ. February 11, 2005.

Bills RJ. AM fungal communities in the Phoenix metropolitan area and the adjacent Sonoran desert: a comparison. 4th Annual California-Oregon Mycorrhizal Meeting. Desert Studies Center, Zyzyx, CA. January 13-15, 2005.

Bills RJ. Arbuscular Mycorrhiza: The Rodney Dangerfield of the ecosystem. Ecology Explorers K-12 Teacher Training workshop, International Institute for Sustainability, Arizona State University, Tempe, AZ. June 21, 2004

\section{POSTER PRESENTATIONS}

Bills RJ, Morton JB. Morphology and an LSU phylogeny reveal Archaeospora trappei and Ar. schenckii are population level variants of one species. $8^{\text {th }}$ International Conference on Mycorrhiza, Flagstaff, AZ. August 3-7, 2015.

Bills RJ, Morton JB. West Virginia University Graduate Student Research Competition, Morgantown, WV. April, 2013

Bills RJ, Morton JB. Combined morphological and molecular analyses to assess the community composition of glomeromycotan fungi in North American grasslands. International Conference of Mycorrhiza at Belo Horizonte, Brazil, August 9-14, 2009

Bills RJ, Stutz JC. Arbuscular mycorrhizal suppression and effects on the productivity of Encelia farinosa (brittlebush) at an urban and a desert site. 5th Annual Western Mycorrhizal Gathering, University of California Bodega Marine Laboratory, Bodega Bay, CA. February 10-12, 2006

Bills RJ, Stutz JC. Effects of arbuscular mycorrhizal fungal suppression on the productivity of Encelia farinosa (brittlebush) at an urban and a desert site. Central Arizona Phoenix-Long Term Ecological Research 8th Annual Poster Symposium. Tempe, AZ. January 19, 2006. 
Bills RJ, Stutz JC. Arbuscular mycorrhizal fungal species richness is lower in the Phoenix metropolitan area in comparison to the surrounding desert. 7th Annual Central Arizona PhoenixLong Term Ecological Research Symposium. Tempe, AZ. January 19, 2005.

Bills RJ, Whitcomb S, Cousins JR, Stutz JC. Comparisons between arbuscular mycorrhizal fungal communities in the Phoenix metropolitan area and surrounding desert. 89th Annual Meeting for the Ecological Society of America. Portland OR. August 1-6, 2004.

Bills RJ, Whitcomb S, Cousins JR, Stutz JC. Differences in arbuscular mycorrhizal fungal community structure at residential and desert land use types. Arizona State University East Graduate Student Poster Symposium, Mesa, AZ. April 16, 2004.

Bills RJ, Whitcomb S, Cousins JR, Stutz JC. Differences in arbuscular mycorrhizal fungal community structure at residential and desert land use types within the CAP LTER. 6th Annual Central Arizona Phoenix Long-Term Ecological Research Symposium. Tempe, AZ. February 23, 2004.

\section{SERVICE}

2014-present Co-leader $4^{\text {th }}$ Grade Children's Ministry, Chestnut Ridge Church, Morgantown, WV

2010-2013 Coach, Upward Youth Basketball, Morgantown, WV

2000-2003 Literacy Tutor, Truckee Meadows Community College, Department of Adult Basic Education, Reno, NV 